\title{
Griffiss AFB Integrated Resource Assessment
}

\section{Volume 2: Electric Baseline Detail}

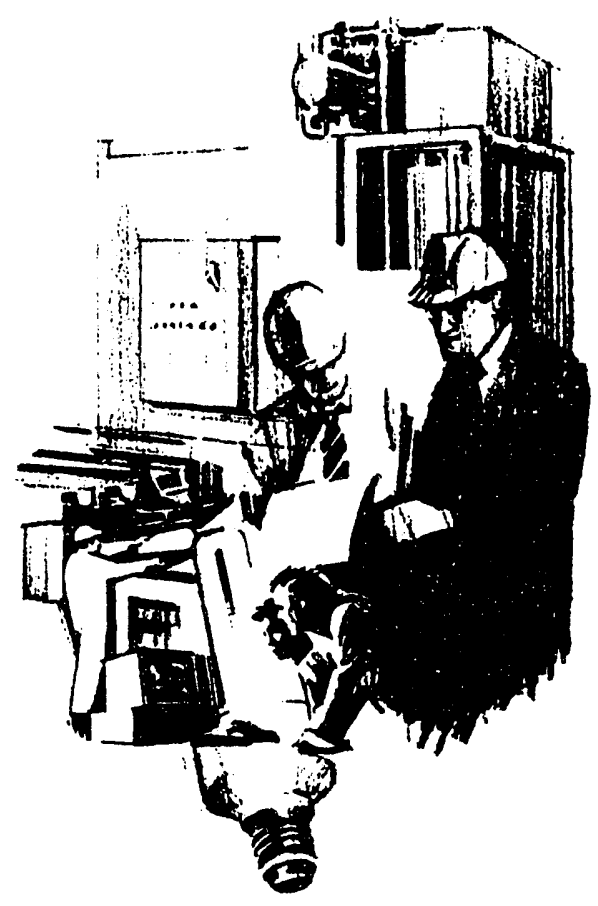

February 1993

Prepared for the U.S. Department of Energy Federal Energy Management Program under Contract DE-AC06-76RLO 1830

Pacific Northwest Laboratory Operated for the U.S. Department of Energy by Battelle Memorial Institute 


\section{DISCLAIMER}

This report was prepared as an account of work sponsored by an agency of the United States Govern: zent. Neither the United States Government nor any agency thereof, nor Battelle Memorial Institute, nor any of their employees, makes any warranty, expressed or implied, or assumes any legal liability or responsibility for the accuracy, completeness, or usefulness of any information, apparatus, product, or process disclosed, or represents that its use would not infringe privately owned rights. Reference herein to any specific commercial product, process, or service by trade name, trademark, manufacturer, or otherwise does not necessarily constitute or imply its endorsement, recommendation, or favoring by the United States Government or any agency thereof, or Battelle Memorial Institute. The views and opinions of authors expressed herein do not necessarily state or reflect those of the United States Government or any agency thereof.

\section{PACIFIC NORTHWEST LABORATORY operated by \\ BATTELLE MEMORIAL INSTITUTE for the}

UNITED STATES DEPARTMENT OF ENERGY under Contract DE-AC06-76RLO 1830

Printed in the United States of America

Available to DOE and DOE contractors fron: the

Office of Scientific and Technical Information, P.O. Box 62, Oak Ridge, TN 37831; prices available from (615) 576-8401. FTS 626-8401.

Available to the public from the National Technical Information Service, U.S. Department of Commerce, 5285 Port Royal Rd., Springfield, VA 22161. 
PNL--8545-Vol .2

DE93 011710

GRIFFISS AFB INTEGRATED RESOURCE ASSESSMENT

VOLUME 2: ELECTRIC BASELINE DETAIL

D. R. Dixon (Project Manager)

P. R. Armstrong

J. M. Keller

February 1993

Prepared for

the U.S. Department of Energy

Federal Energy Management Program

under Contract DE-AC06-76RLO 1830

Pacific Northwest Laboratory

Richland, Washington 99352 


\section{ABSTRACT}

The UI.S. Air Force Air Combat Command has tasked the Pacific Northwest Laboratory (PNL) ${ }^{(a)}$ as the lead laboratory supporting the U.S. Department of Energy (DOE) Federal Energy Management Program's (FEMP) mission to identify, evaluate, and assist in acquiring all cost-effective energy projects at Griffiss Air Force Base (AFB). This is a model program PNL is designing for federal customers served by the Niagara Mohawk Power Company (Niagara Mohawk). It will 1) identify and evaluate all electric cost-effective energy projects; 2) develop a schedule at each installation for project acquisition considering project type, size, timing, and capital requirements, as well as energy and dollar savings; and 3) secure $100 \%$ of the financing required to implement electric energy efficiency projects from Niagara Mohawk and have Niagara Mohawk procure the necessary contractors to perform detailed audits and install the technologies.

This report documents the assessment of baseline energy use at one of Niagara Mohawk's primary federal facilities, Griffiss AFB, an Air Combat Command facility located near Rome, New York. It is a companion report to Volume 1, the Executive Summary, and Volume 3, the Electric Resource Assessment. The analysis examines the characteristics of electric, gas, oil, propane, coal, and purchased thermal capacity use for fiscal year (FY) 1990. The results include energy-use intensities for the facilities at Griffiss AFB by building type and electric energy end use. A complete electric energy consumption reconciliation is presented that accounts for the distribution of al1 major electric energy uses and losses among buildings, utilities, and central systems.

(a) Pacific Northwest Laboratory is operated for the U.S. Department of Energy by Battelle Memorial Institute under Contract DE-AC06-76RLO 1830. 


\section{SUMMARY}

The U.S. Air Force Air Combat Command (ACC) has tasked the Pacific Northwest Laboratory (PNL) as the lead laboratory supporting the U.S. Department of Energy (DOE) Federal Energy Management Program's (FEMP) mission to identify, evaluate, and assist in acquiring all cost-effective energy projects at Griffiss AFB. This model integrated resource planning (IRP) program is being developed by PNL for federal customers served by the Niagara Mohawk Power Company (Niagara Mohawk).

This volume, Electric Baseline Detail, documents baseline energy use at the ACC Griffiss AFB facility located near Rome, New York. The analysis characterizes electric, natural gas, \#2 fuel oil, propane, purchased hightemperature hot water, and coal use for fiscal year (FY) 1990. It provides a breakdown of electric energy-use for the Griffiss AFB facilities by building type and energy end use. A complete electric energy consumption reconciliation is presented that includes an accounting of all electric energy use among buildings, utilities, central systems, and distribution losses.

In FY 1991, over 9,650 active military personnel were stationed at Griffiss AFB. The base's primary mission is to provide training and support for the $416^{\text {th }}$ Bombardment Wing. The 3,000-acre facility was divided, for energy consumption and billing purposes, into three major sectors: on-post utility (including exterior lighting, pumping, and transmission and distribution losses); commercial; and family housing. Of these three sectors, two contain non-utility buildings whose energy use is generally correlated with building function and floor area. Table S.l summarizes the number of buildings and total square feet for each of the areas. The base contains 577 buildings, for a total area of $6,012,574 \mathrm{ft}^{2}$.

Table S.2 summarizes the typical yearly energy consumption and cost for all facilities at Griffiss AFB. For each energy type, the yearly total is shown in units appropriate to the energy type and in a common unit (MBtu) as a basis for comparison. The total consumption values represent typical current yearly usage, from the best available data during 1990 and 1991 . The yearly energy consumption was $1,252,965 \mathrm{MBtu}$ at a cost of $\$ 8,346,000$. 
IABLE S.1. Griffiss AFB Building Characterization

\begin{tabular}{|c|c|c|c|}
\hline Energy Use Sector & $\begin{array}{l}\text { Number of } \\
\text { Buildings }\end{array}$ & $\begin{array}{c}\text { Total Floorspace } \\
\left(\mathrm{ft}^{2}\right)\end{array}$ & $\begin{array}{c}\text { Percent of } \\
\text { Total Floorspace }\end{array}$ \\
\hline $\begin{array}{l}\text { Commercial } \\
\text { Family Housing }\end{array}$ & $\begin{array}{l}263 \\
314\end{array}$ & $\begin{array}{l}4,988,490 \\
1,024,084\end{array}$ & $\begin{array}{r}83.0 \\
17.0 \\
\end{array}$ \\
\hline Total & 577 & $6,012,574$ & 100.0 \\
\hline
\end{tabular}

TABLE S.2. Typical Yearly Energy Consumption and Energy Cost at Griffiss AFB

\begin{tabular}{|c|c|c|c|c|c|}
\hline Eneray Type & Yearly Total & $\begin{array}{c}\text { Yearly } \\
\text { Iotal [MBtu (a)] }\end{array}$ & $\begin{array}{l}\text { Percent of } \\
\text { Total Energy } \\
\text { Consumption }\end{array}$ & $\begin{array}{l}\text { Energy Cost } \\
{\left[19905 \times 10^{3}\right]}\end{array}$ & $\begin{array}{l}\text { Percent of } \\
\text { Total Cost }\end{array}$ \\
\hline $\begin{array}{l}\text { Electricity } \\
\text { Natural Gas } \\
\text { \$2 Fuel 011 } \\
\text { Propane } \\
\text { Coal } \\
\text { Purchased Steam }\end{array}$ & $\begin{array}{rl}85,935 & \text { Mh } \\
1,109 & \mathrm{ktherm} \\
218 & \mathrm{kgall} \text { on } \\
20 & \mathrm{kgall} \text { on } \\
26,450 \text { Tons } \\
168,580 \text { kpound }\end{array}$ & $\begin{array}{r}293.211^{(b)} \\
110.990^{(c)} \\
30,271^{(d)} \\
1.818(\mathrm{e}) \\
648.095^{(\mathrm{f})} \\
168.580^{(\mathrm{g})}\end{array}$ & $\begin{array}{r}22.5 \\
9.0 \\
2.5 \\
0.1 \\
52.2 \\
13.7 \\
\end{array}$ & $\begin{array}{r}5,200 \\
596 \\
122 \\
13 \\
1.080 \\
1.335 \\
\end{array}$ & $\begin{array}{r}62.3 \\
7.1 \\
1.5 \\
0.01 \\
13.0 \\
16.0 \\
\end{array}$ \\
\hline Totals: & & 1.252 .965 & 100.0 & 8.346 & 100.01 \\
\hline
\end{tabular}

(a) 1 MBtu $=1,000,000$ Btu.

(b) 3,413 Btu/kth.

(c) $100,000 \mathrm{Btu} /$ therm; $1,050 \mathrm{Btu} / \mathrm{ft}^{3}$ of natural gas.

(d) $0.1388 \mathrm{MBtu} / \mathrm{gal}$ of 2 fuel oil.

(e) $0.0913 \mathrm{MBtu} / \mathrm{gal}$ of propane.

(f) $24.5 \mathrm{MBtu} / \mathrm{ton}$ of coal.

(g) $1000 \mathrm{Btu} /$ pound (mass) of steam.

Table 5.3 breaks down the electric energy consumption (MWh/yr) by end use for the base's three major areas.

The scope of this assessment includes only electric energy. The baseline use of other fuels has therefore not been analyzed in detail. Overall use of the fuels is reported only for completeness.

This report is organized in nine sections. Section 1 describes the mission, geography, climate, utilities, buildings and occupancy characteristics. Section 2 describes energy sources. Section 3 presents detailed electric energy consumption, demand and time-of-use data as compiled from logs, billing records, standard reporting forms and computer files. Sections 4 through 8 outline the site's non-vehicular consumption of other fuel types. Section 9 presents estimates of end-use electric energy consumption by building type and utility. The Section 9 estimates are the primary result of the baseline 
TABLE S.3. Energy Consumption by End Use (MWh/yr)

\begin{tabular}{|c|c|c|c|c|}
\hline \multirow[b]{2}{*}{ Fuel Type/End Use } & \multicolumn{4}{|c|}{ Base Area } \\
\hline & Commercial & $\begin{array}{l}\text { Family } \\
\text { Housing }\end{array}$ & Utility & Total \\
\hline $\begin{array}{l}\text { Electric: } \\
\text { Vent/Fans } \\
\text { Lighting } \\
\text { Cooling } \\
\text { Cooking } \\
\text { Refrigeration } \\
\text { Otiner Bldg. End-Use } \\
\text { Str. and Ext. Ltg. } \\
\text { Trans. \& Dist. Loss } \\
\text { Central Plant }\end{array}$ & $\begin{array}{r}6,499 \\
27,467 \\
15,087 \\
732 \\
1,944 \\
16,737 \\
0 \\
0 \\
0\end{array}$ & $\begin{array}{r}110 \\
1,573 \\
10 \\
513 \\
974 \\
1,385 \\
104 \\
0 \\
0\end{array}$ & $\begin{array}{r}0 \\
0 \\
0 \\
0 \\
0 \\
0 \\
2,157 \\
7,817 \\
2,800\end{array}$ & $\begin{array}{r}6,941 \\
28,909 \\
15,100 \\
1,245 \\
3,201 \\
20,090 \\
2,261 \\
7,817 \\
2,800\end{array}$ \\
\hline $\begin{array}{l}\text { Total } \\
\text { Percent of Total }\end{array}$ & $\begin{array}{r}68,466 \\
79.8\end{array}$ & $\begin{array}{r}4,564 \\
5.3\end{array}$ & $\begin{array}{r}12,774 \\
14.9\end{array}$ & $\begin{array}{r}85,804 \\
100.0\end{array}$ \\
\hline
\end{tabular}

analysis and the most detailed level to which energy use is generally traced in a site-wide conservation potential assessment. Upon selection of specific projects, energy use may be traced to a finer level of detail by itemizing the characteristics and operating hours of each piece of end-use equipment. This has been done in the analysis of certain specific energy conservation or fuelswitching measures (see Volume 3 ), but such detail is not generally needed to develop a valid energy use baseline. Sections 10 and 11 list the references and general site documentation material used to develop the energy baseline for Griffiss AFB. Three appendixes contain supplemental information. 


\section{CONTENTS}

\section{ABSTRACT}

SUMMARY

1.0 PHYSICAL CHARACTERISTICS

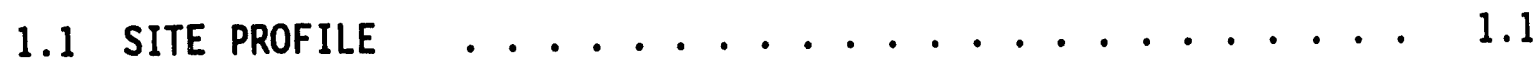

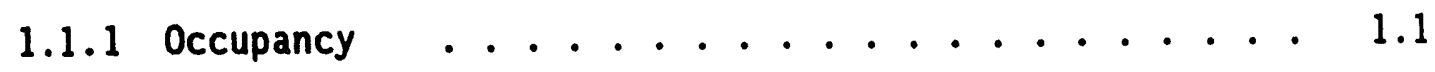

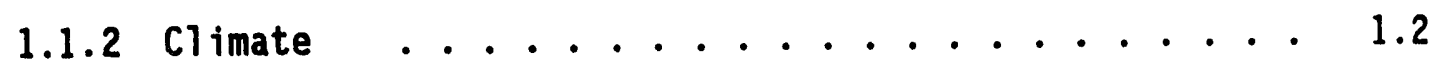

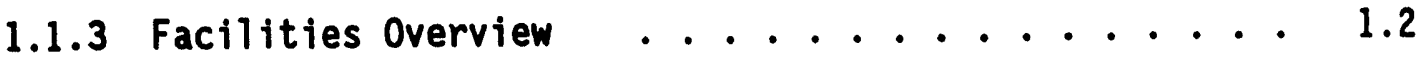

1.2 BUILDING AND FACILITY PROFILE . . . . . . . . . 1.5

1.2 .1 Buildings ..................... 1.5

1.2.2 Family Housing Characterization ........ 1.8

1.2.3 Central Thermal System Characterization ...... 1.11

1.2.4 Utility Characterization ............ 1.13

2.0 ENERGY SOURCE CHARACTERISTICS . . . . . . . . . . 2.1

2.1 ELECTRIC SUPPLY SOURCE DESCRIPTION . . . . . . . 2.2

2.2 NATURAL GAS SUPPLY SOURCE DESCRIPTION . . . . . . . 2.4

2.3 OIL SUPPLY SOURCE DESCRIPTION . . . . . . . . . . 2.4

2.4 PROPANE SUPPLY SOURCE DESCRIPTION . . . . . . . . . 2.4

2.5 COAL SUPPLY SOURCE DESCRIPTION ................... 2.4

2.6 PURCHASED STEAM SOURCE DESCRIPTION . . . . . . . 2.5

3.0 ElECTRIC CONSUMPTION . . . . . . . . . . . . . . 3.1

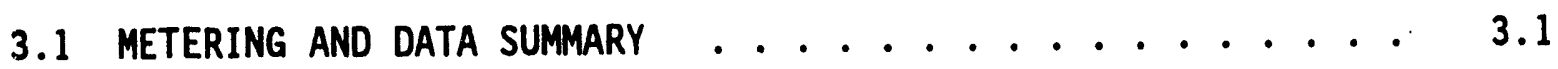

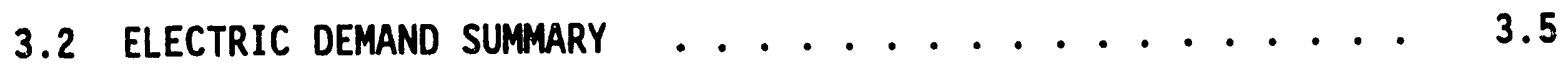

3.2.1 Time-of-Use Characterization ........ 3.5

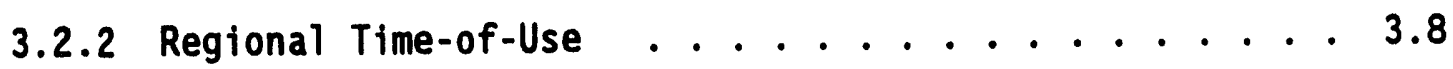


3.2.3 Consumption, Peak Demand and Reactive Demand Growth . 3.10

3.2 .4 Load Curves .. . . . . . . . . . . . . . 3.10

4.0 NATURAL GAS CONSUMPTION . . . . . . . . . . . . . . . . . . 4.1

4.1 METERING AND DATA SUMMARY . . . . . . . . . . . . . . . . 4.1

4.2 ENERGY USE BREAKDOWN . . . . . . . . . . . . . . . . . 4.1

5.0 OIL CONSUMPTION

5.1 METERING AND DATA SUMMARY ................. 5.1

5.2 ENERGY USE BREAKDOWN ................... . . . 5.1

6.0 PROPANE CONSUMPTION . . . . . . . . . . . . . . . . . . . . 6.1

6.1 METERING AND DATA SUMMARY . . . . . . . . . . . . . 6.1

6.2 ENERGY USE BREAKDOWN ................... . . 6.1

7.0 COAL CONSUMPTION . . . . . . . . . . . . . . . . . . . . 7.1

7.1 METERING AND DATA SUMMARY . . . . . . . . . . . . . . 7.1

7.2 ENERGY USE BREAKDOWN ......................... 7.1

8.0 PURCHASED STEAM CONSUMPTION . . . . . . . . . . . . . . . . . . . 8.1

8.1 METERING AND DATA SUMMARY . . . . . . . . . . . . . 8.1

8.2 ENERGY USE BREAKDOWN ................... 8.1

9.0 ENERGY-USE INTENSITIES . . . . . . . . . . . . . . . . . . . 9.1

9.1 INITIAL ENERGY-USE INTENSITY DATA

9.2 SUMMARY OF INITIAL ENERGY END-USE VALUES...$\cdots 9$

9.3 ENERGY USE BY BUILDING TYPE . . . . . . . . . . . . . . . . . 9.10

9.4 ENERGY-USE INTENSITIES BY END USE . . . . . . . . . . . . . 9.11

10.0 REFERENCES . . . . . . . . . . . . . . . . . . . . . . 10.1

11.0 SITE DATA SOURCES . . . . . . . . . . . . . . . . . . . 11.1 


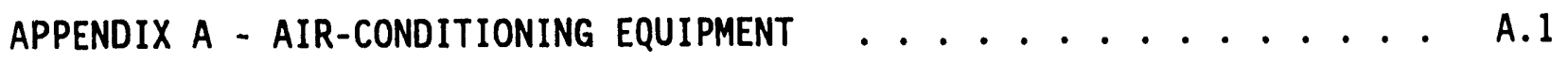

APPENDIX B - LAMP REPLACEMENT RECORDS . . . . . . . . . . B. B

APPENDIX C - DOMESTIC REFRIGERATION ............. C.1 


\section{FIGURES}

1.1 Aerial View of Griffiss AFB . . . . . . . . . . . 1.4

3.1 Monthly Average Weekday Electric Load Profiles . . . . . . 3.6

3.2 Monthly Average Weekend Electric Load Profiles . . . . . . 3.6

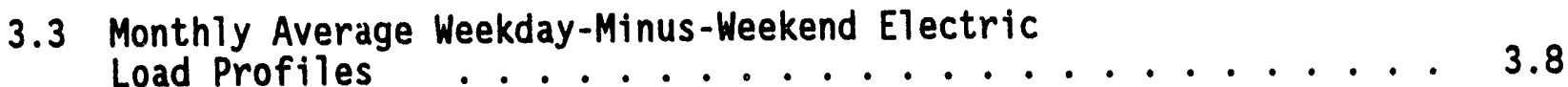

3.4 Comparison of Griffiss AFB Weekday Load Profiles and Niagara
Mohawk Utility-Wide Workday Load Profiles . . . . . . . 3.9

3.5 Niagara Mohawk Monthly Billing Data from 4/88 to 11/92 . . . . 3.11

3.6 Monthly Peak Shaving Energy Cost Component . . . . . . . . 3.12

3.7 Annual Peak Shaving Energy and Maintenance Cost Components . . . 3.13 


\section{IABLES}

S.1 Griffiss AFB Building Characterization ........... vi

S.2 Typical Yearly Energy Consumption and Energy Cost at Griffiss AFB ......................... vi

S.3 Energy Consumption by End Use .............. vii

1.1 Lescriptions of Buildings Types Used to Establish

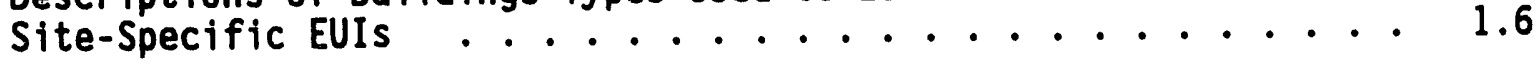

1.2 Definition of Building Type Used to Establish

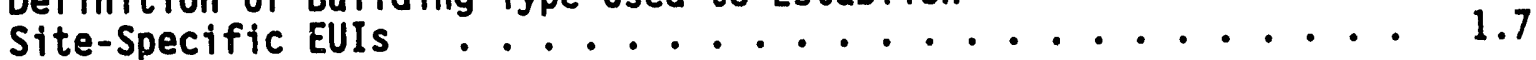

1.3 Building Characteristics by Building Type . . . . . . 1.9

1.4 Age Distribution by Building Type . . . . . . . . . . . 1.10

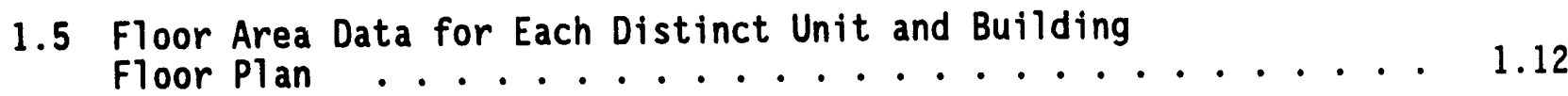

1.6 Floor Area by Building Type and Electric Distribution Feed Based on

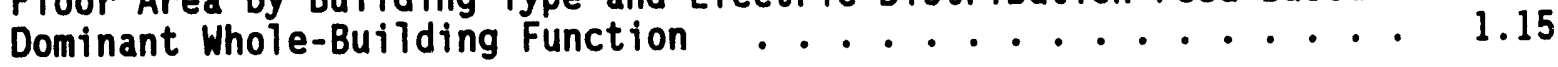

1.7 Transformer Schedule for Distribution System Upgrade . . . . . 1.16

1.8 Sewer Lift Pump Inventory ............... 1.17

1.9 Street and Exterior Light Inventory ............. . 1.19

2.1 Typical Yearly Energy Consumption for FY 1990 at Griffiss AFB . . 2.1

2.2 Gasoline and Diesel Generators of 20 k'JA or Greater

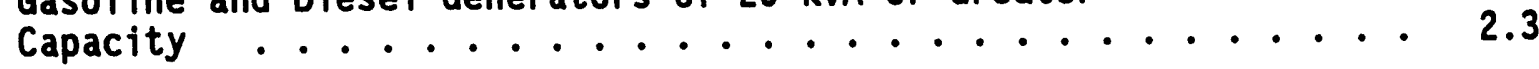

3.1 Niagara Mohawk Electric Billing Data and Corresponding Average Loads ................... 3.2

3.2 Electric Consumption at Other Niagara Mohawk Feed Points ..... 3.3

3.3 Electric Consumption Data for Buildings with Meters that are Read on a Regular Monthly Basis ............ 3.4

3.4 Electric Meters Sampled by the EMCS . . . . . . . . . 3.5

9.1 Regional EUI Survey Results . . . . . . . . . . . 9.2

9.2 Saturation Weighted EUI Survey Results . . . . . . . . 9.4 
9.3 Regional Fossil Fuel EUI Survey Results . . . . . . . . . 9.5

9.4 Regional EUIs (min/median/max) Applied to the GAFB EUI Analysis ..................... 9.10

9.5 Annual Electric Consumption by Building Type and

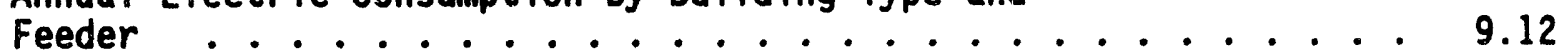

9.6 Electric EUIs by Building Type and End Use . . . . . . . . . 9.14 


\subsection{PHYSICAL CHARACTERISTICS}

This section provides an overview of the site and facilities and summarizes the $\mathrm{climate}$ and the physical and functional characteristics that influence energy use at Griffiss Air Force Base.

\subsection{SITE PROFILE}

Griffiss Air Force Base (Griffiss AFB) is a 3,000-acre Air Combat Command (ACC) facility. The base is situated a few miles northeast of Rome, New York, at $43.2^{\circ} \mathrm{N}$ and $75.4^{\circ} \mathrm{E}$ and at an elevation of 514 feet. The site is bounded on the west by the Mohawk river and on the south by New York State Route 49 and the New York State Barge Canal.

\section{1 .1 Occupancy}

The base mission is support of the $416^{\text {th }}$ Bombardment Wing. The Wing consists of the $41^{\text {st }}$ Air Refueling Squadron, which operates and maintains tankers, and the $668^{\text {th }}$ Bomb Squadron, which operates and maintains heavy bombers and cruise missiles.

Upon transfer of command from Strategic Air Command to ACC in June 1992, the base's mission emphasis changed from strategic preparedness to global mobility. This shift has had little effect on facility (non-vehicular) energy use.

There are two major tenants on the base. The $485^{\text {th }}$ Engineering Installation Group installs radar stations throughout the world. Rome Labs conducts testing, research, and development involving radar and other electro-magnetic phenomena. The $933^{\text {rd }}$ Civil Engineering Reserve Squadron is also housed at Griffiss AFB as a tenant.

The daytime population on the base averaged 9,650 in FY 1991, and consisted of active military personnel and dependents as well as civilian employees. Active military personnel assigned to the site numbered 4,550. The estimated number of military dependents was 2,400. About half of the military personnel and their dependents lived in military housing. The number of 
families with two or more active military people assigned to Griffiss AFB was not determined but is reportedly small. Reserve training occurs in Building 303. Civilians employed full-time at the site numbered 2,700 in FY 1991. These personnel did not live in military housing. Active and retired military personnel not assigned to the site affect energy consumption to some extent by their use of site facilities such as the branch exchange (BX) and recreation centers. There are some 50,000 people in upstate New York who are entitled to use the facilities; the extent of use by this group has not been determined but is considered small.

\subsubsection{Climate}

The regional climate is influenced by the Great Lakes and the Canadian Shield. The local climate is influenced by the site's location in the broad valley of the Mohawk River, which is surrounded by low hills. Heating degreedays, based on a $65^{\circ} \mathrm{F}$ base temperature, average 7,331 Fahrenheit degreedays/yr at the Griffiss AFB weather station. The distribution of daily heating load can be estimated from the Syracuse, New York, data (Balcomb et al. 1980) tabulated below.

Degree-Day Base Temperature $\left({ }^{\circ} \mathrm{F}\right): \quad 50 \quad 55 \quad 60 \quad 65 \quad 70$

Normal Annual Heating Degree Days ( ${ }^{\circ} \mathrm{F}$-day): 3,215 4,218 5,366 6,678 8,192

Design conditions according to 1985 Fundamentals (ASHRAE 1985) follow.

The 97.5 and $99 \%$ design temperatures for the Griffiss AFB weather station are -5 and $-11^{\circ} \mathrm{F}$. The base-65 degree-day logs of Griffiss AFB weather station show 6,257 and 6,327 heating degree-days and 475 and 535 cooling degree-days in the fiscal years (October 1-September 30) 1990 and 1991. Dry bulb temperature exceeds $83^{\circ} \mathrm{F}$ an average of $440 \mathrm{hr} / \mathrm{yr}$ (average wet bulb temperature of $69^{\circ} \mathrm{F}$ ) and exceeds $88^{\circ} \mathrm{F}$ only $90 \mathrm{hr} / \mathrm{yr}$ (average wet bulb temperature of $71^{\circ} \mathrm{F}$ ). Wet bulb temperature exceeds $71^{\circ} \mathrm{F}$ an average of $440 \mathrm{hr} / \mathrm{yr}$ and exceeds $75^{\circ} \mathrm{F}$ an average of $88 \mathrm{hr} / \mathrm{yr}$.

Design conditions according to Engineering Weather Data (USAF 1978) follow. The $97.5 \%$ and $99 \%$ design temperatures for the Griffiss AFB weather station are -5 and $-11^{\circ} \mathrm{F}$. Dry bulb temperature exceeds $80^{\circ} \mathrm{F}$ an average of 
$306 \mathrm{hr} / \mathrm{yr}$ and exceeds $93^{\circ} \mathrm{F}$ only $3 \mathrm{hr} / \mathrm{yr}$. Wet bulb temperature exceeds $67^{\circ} \mathrm{F}$ an average of $611 \mathrm{hr} / \mathrm{yr}$ and exceeds $73^{\circ} \mathrm{F}$ an average of $84 \mathrm{hr} / \mathrm{yr}$.

\subsubsection{Facilities Overview}

An aerial view of Griffiss AFB is shown in Figure 1.1. There are 262 commercial, industrial, command, and airfield support buildings with a total floor area of about 4,983,000 $\mathrm{ft}^{2}$. Most of these buildings are located in a 100-acre area near the center of the base. Hangars are located just east of this area, and command and military operations functions are concentrated in buildings to the south and east of the central commercial area. The combined area of the 14 hangars and aircraft shops is about $847,000 \mathrm{ft}^{2}$. The hangars are lit by high-intensity discharge lights (mercury vapor, high-pressure sodium [HPS] and low-pressure sodium [LPS]) of various types and wattages that typically operate 24 hours/day. The most intense energy use occurs in the secure command and communications buildings.

There are two permanent on-post family housing areas containing a total of 735 family dwelling units with a total floor area of about $1,024,000 \mathrm{ft}^{2}$. The Skyline area is south, and the Woodhaven area is south and west of the central commercial area. These two housing areas have natural gas service, for space and domestic water heating. Electric cooking appliances are used in both areas. A mobile home park provides space, electrical service, and water and sewer service for 50 units. There are also five single-family units (circa. 1940) north of the golf course.

The airfield lighting consists of 200 incandescent runway lights and 700 incandescent taxiway lights. One hundred ninety-two $250 \mathrm{~W}$ HPS fixtures provide security lighting on each of two aircraft parking aprons. There is also extensive security lighting on the exteriors of all the hangar buildings.

Bulk fuel storage tanks are located at the southmost tip of the base. Fuel is pumped to the airfield by a system of fixed pumps and distribution pipes.

Off-base facilities include a number of radar test sites and the Hancock Field facility in syracuse. These facilities are not included in this assessment of baseline energy use. 


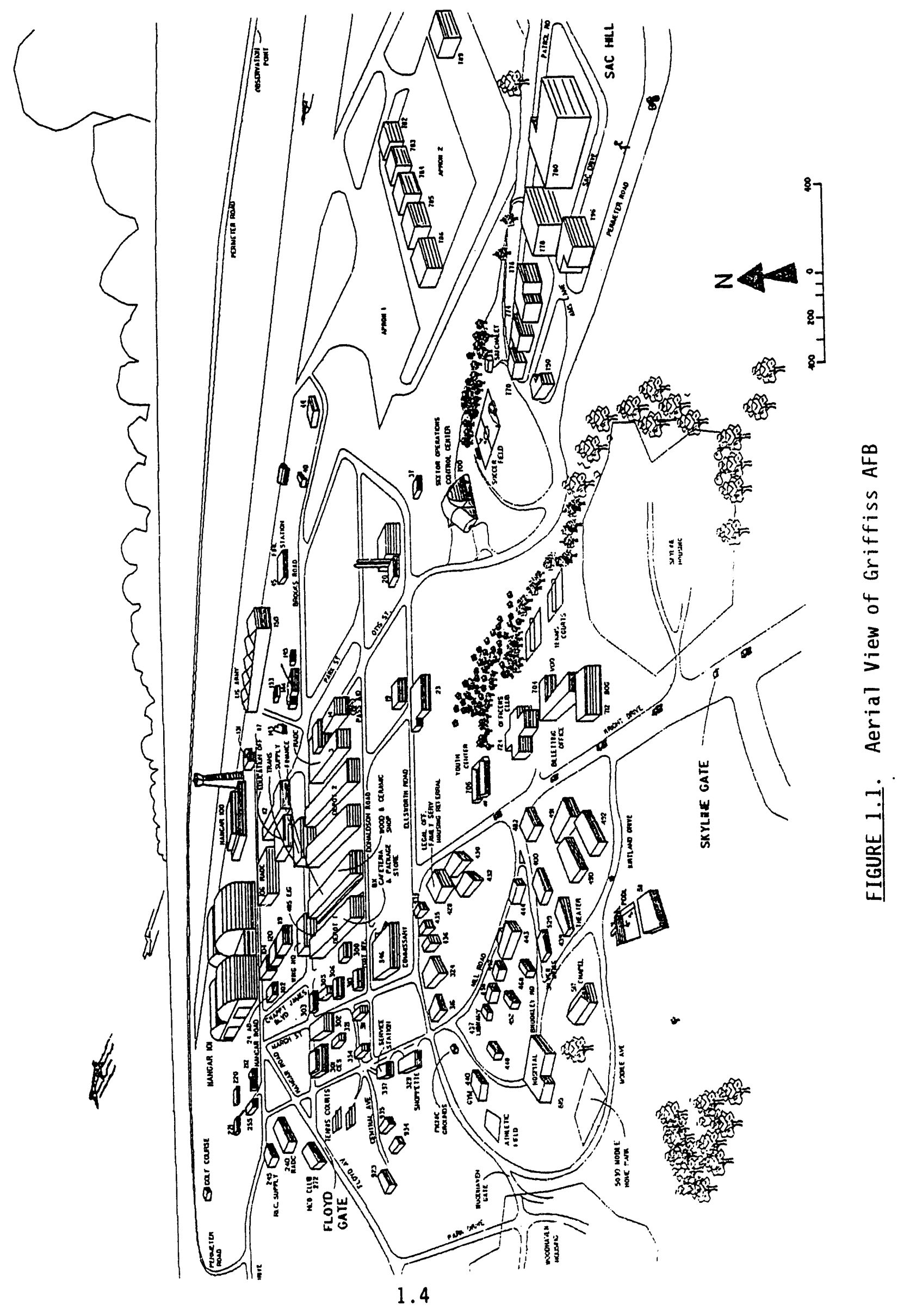




\subsection{BUILDING AND FACILITY PROFILE}

The site facilities at Griffiss AFB consist of family housing and commercial buildings (henceforth referred to simply as "buildings" in this report), and other real property improvements such as utilities (water, sewer, street lighting, gas, steam, and electricity), mission-specific facilities (antennas, runways, fuel storage tanks, etc.), outdoor recreation (tennis courts, track, playing fields, etc.), and other surface improvements (streets, culverts, fences and parking lots). There is little irrigation at the base.

All of the major non-vehicular energy-using facilities have been classified using 41 primary building types and five utility categories.

\subsubsection{Buildings}

The building types are based on identifiable function or uniqueness in terms of factors that affect energy use. These factors include occupancy, connected load mix, and operation. Age can be a factor but was not considered at Griffiss AFB because most of the buildings were built before the 1973 oil embargo. A building may be treated as two or more buildings, each of a different type, when significant portions of its floor area serve different functions. The Real Property Database for Griffiss AFB includes Department of Defense (DOD) (Air Force version) category codes which identify the function of each building listed. Some category codes describe buildings that are very similar in terms of energy use. Groups of codes have therefore been aggregated into higher-level building type categories for the purposes of this assessment. The abbreviations used for each aggregate building type and a brief definition of each type are listed in Table 1.1. The Air Force Real Property Category codes corresponding to each building type are listed in Table 1.2.

Building sub-types have been identified where significant differences in style of construction, age, hours of operation, or connected load mix result in significant differences in energy-use intensity (EUI). For example, dwelling units of the Woodhaven and Skyline housing areas form two family housing sub-types because the average basement to living space floor area ratios 
TABLE 1.1. Descriptions of Butlding Types Used to Establish Site-Specific EUIs

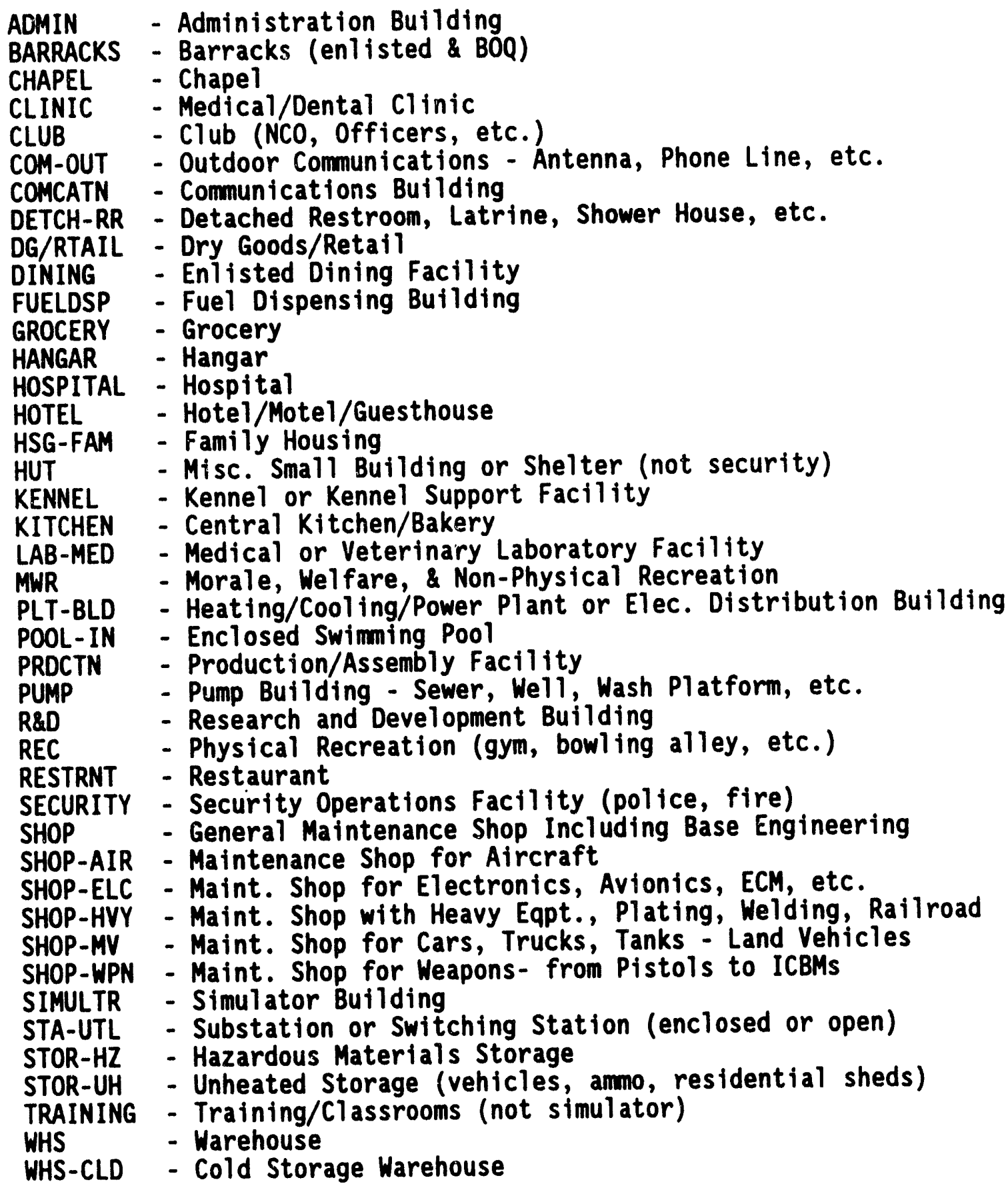


TABLE 1.2. Definition of Building Type Used to Establish Site-Specific EUIs (Each building type is defined in terms of the Real Property Category Codes [USAF/LEEP 1990] included in each building type.)

\begin{tabular}{|c|c|}
\hline$\frac{\text { BIdg Type }}{\text { ADMIN }}$ & $\begin{array}{l}\text { Category Codes (Griffiss AFB Real Property Database) } \\
121111,141453,141461,141743,141745,141753,171471,510125,510111,610112,610119,610121,6101 \\
22,610127,610128,610129,610142,610241,610243,610249,610281,610282,610284,610286,610711,6 \\
10717,610811,610911,610913,610915,730443,740253,740396,740459\end{array}$ \\
\hline BARRACKS & $141459,721312,721315,724415,724417,725517$ \\
\hline CHAPEL & 730773.730774 \\
\hline CLUB & 750422 \\
\hline COM-OUT & $132134,133314,134355,134473,134678,149621,149622.149623,149624,149965$ \\
\hline COMCATN & $131111,131138,134351,134375,134465,141446,149962,371485$ \\
\hline DETCH-RR & 723392 \\
\hline DG/RTAIL & $740155,740269,740382,140383,740388,740389$ \\
\hline DINING & $510212,722351,740615,71,0617,740618$ \\
\hline FUELDSP & 121124,123335 \\
\hline GROCERY & 740266 \\
\hline HANGAR & $211111,211159,211173,211177,211179,740317$ \\
\hline HOSPITAL & $510001,510175,510275,510342,510672,510712$ \\
\hline HOTEL & 740443 \\
\hline HSG-FAM & 711111.711144 \\
\hline HUT & $141627,141629,690625,730275,750811$ \\
\hline KENNEL & 730841 \\
\hline LAB-MED & $218868,510143,740270$ \\
\hline MWR & $510915,740316,740665,740675,740873,740883,740884,750371$ \\
\hline PLT-BLD & $811149,821156,824462$ \\
\hline POOL-IN & 750812 \\
\hline PRDCTN & 212212 \\
\hline PUMP & $125977,411123,411128,822248,832267,841166,841169,842249,843316$ \\
\hline RED & $317311,317315,319441,319443,390311$ \\
\hline REC & 740671.740674 \\
\hline RESTRNT & 722345,740735 \\
\hline SECURITY & $730142,730832,730833,730835,730836,730837,730838,730839$ \\
\hline SHOP & $211153,218712,218852,219943,219944,422256$ \\
\hline SHOP-AIR & 211152.211154 .211157 \\
\hline SHOP-ELC & $217712,217722,217735,217762$ \\
\hline SHOP-HVY & 218842 \\
\hline SHOP-MV & $214422,214425,214467$ \\
\hline SHOP-WPN & $171476,212215,212216.215552,215582.216642$ \\
\hline SIMULTR & 171212 \\
\hline STA-UTL & 813228.813231 \\
\hline STOR-HZ & 442257 \\
\hline STOR-UH & $214428,219946,422253,422257,422258,422264,422265,442628,510264,711311,714431$ \\
\hline TRAINING & $171356,171618,179511.730441$ \\
\hline WHS & $214426,319995,442515,442758,442765,442769,510713,740387,740672$ \\
\hline WHS-CLD & 432283 \\
\hline
\end{tabular}


differ significantly, the farmhouses form another sub-type, and the mobile home units constitute a third family housing sub-type.

Table 1.3 lists the important aggregate characteristics of aggregate floor area, fuel type and number of structures for each building type represented at Griffiss AFB. Table 1.4 gives the age distribution of buildings by building type.

\subsubsection{Family Housing Characterization}

Permanent family housing at Griffiss AFB is located mainly in two areas that each contain a $m i x$ of structures ranging from single-family to six-unit row-house structures. There is also variety in the unit floor plans of the housing stock, with the number of bedrooms ranging from two to four and the floor area ranging from 934 to $2,756 \mathrm{ft}^{2}$. The Woodhaven area contains 270 dwelling units in 143 structures, and the Skyline area contains 460 dwelling units in 166 structures. Space and domestic water heating are provided by natural-gas-fired furnaces and water heaters in the Woodhaven and Skyline housing areas. Site documentation (see Appendix A) indicates that one Skyline unit is air conditioned.

The apparent occupant density differs significantiy between the Woodhaven and Skyline housing areas. Assuning the number of occupants equals the number of bedrooms plus one, Woodhaven has an occupant count of 1,707 and an occupant density of $392.4 \mathrm{ft}^{2} /$ occupant, and Skyline has an occupant count of 1,192 and an occupant density of $283.8 \mathrm{ft}^{2} /$ occupant. This difference is apparent in both natural gas and electric energy consumption numbers reported in Sections 4.1 and 9.4 of this report. The reported numbers indicate that energy use per occupant is more constant than energy use per unit floor area. The inclusion of unfinished basement area in the Real Property Database is the most likely reason for this discrepancy.

There are an additional five "farmhouses" which accommodate senior officers and their families. These existed on the site when Griffiss AFB was built. The farmhouses are heated by fuel oil-fired furnaces and have electric water heaters, ranges and clothes dryers. Site documentation (see Appendix A) indicates that at least two farmhouses are air conditioned. 
IABLE 1.3. Building Characteristics by Building Type (This disaggregation is based on dominant whole-building function)




IABLE 1.4. Age Distribution (count and floor area) by Butlding Type (This disaggregation is based on dominant whole-building function)

\begin{tabular}{|c|c|c|c|c|c|c|c|c|c|c|}
\hline \multirow{2}{*}{\begin{tabular}{|l|} 
Decade: \\
Bidg. Type
\end{tabular}} & \multicolumn{2}{|r|}{$1940-49$} & \multicolumn{2}{|c|}{$1950-59$} & \multicolumn{2}{|c|}{$1960-69$} & \multicolumn{2}{|c|}{$1970-79$} & \multicolumn{2}{|c|}{$1980-92$} \\
\hline & Qty. & Area & Qty. & Area & Qty. & Area & Qty.] & Area & Qty. & Area \\
\hline $\begin{array}{l}\text { ADMIN } \\
\text { BARRACKS }\end{array}$ & $\begin{array}{r}11 \\
1\end{array}$ & $\begin{array}{r}231.211 \\
6,136\end{array}$ & $\begin{array}{l}10 \\
11\end{array}$ & $\begin{array}{l}122.967 \\
237.795\end{array}$ & $\begin{array}{l}4 \\
3\end{array}$ & $\begin{array}{l}29,600 \\
24,845\end{array}$ & 1 & 400 & $\begin{array}{l}1 \\
1\end{array}$ & $\begin{array}{r}3,330 \\
81.144\end{array}$ \\
\hline $\begin{array}{l}\text { CHAPEL } \\
\text { CLUB }\end{array}$ & & & & & 1 & 6,199 & 1 & 25,858 & & \\
\hline COM-OUT & & & 2 & 490 & & & 1 & 165 & & \\
\hline $\begin{array}{l}\text { COMCATN } \\
\text { DETCH-RR }\end{array}$ & 1 & 20.577 & 2 & 592 & $\begin{array}{l}5 \\
2\end{array}$ & $\begin{array}{r}8,638 \\
171\end{array}$ & & & $\begin{array}{l}5 \\
2\end{array}$ & $\begin{array}{r}40.520 \\
164\end{array}$ \\
\hline DG/RTAIL & & & 1 & 4.867 & 1 & 2.535 & & & 1 & 4.717 \\
\hline $\begin{array}{l}\text { DINING } \\
\text { FUELOSP }\end{array}$ & 1 & 16,611 & $\begin{array}{l}2 \\
5\end{array}$ & $\begin{array}{r}33.273 \\
7.310\end{array}$ & 1 & 580 & & & 1 & 39,950 \\
\hline $\begin{array}{l}\text { GROCERY } \\
\text { HANGAR }\end{array}$ & 3 & 664,977 & 5 & 150,321 & & & 1 & 53.654 & & \\
\hline $\begin{array}{l}\text { HOSPITAL } \\
\text { HOTEL }\end{array}$ & & & & & & & $\begin{array}{l}1 \\
3\end{array}$ & $\begin{array}{r}102.800 \\
15.963\end{array}$ & & \\
\hline $\begin{array}{l}\text { HSG-FAM } \\
\text { HUT }\end{array}$ & 5 & 15,867 & 166 & 669,873 & $\begin{array}{r}143 \\
3\end{array}$ & $\begin{array}{r}338.344 \\
2.973\end{array}$ & & & 1 & 1.421 \\
\hline $\begin{array}{l}\text { KENNEL } \\
\text { LAB-MED }\end{array}$ & 1 & 19,572 & & & & & & & 1 & 1.920 \\
\hline & 2 & 18,420 & 2 & 18.371 & & & 2 & 18,905 & & \\
\hline $\begin{array}{l}\text { PLT-BLD } \\
\text { POOL-IN }\end{array}$ & & & & & $\begin{array}{l}2 \\
1\end{array}$ & $\begin{array}{l}1.140 \\
5.177\end{array}$ & 1 & 216 & 9 & 76,958 \\
\hline $\begin{array}{l}\text { PRDCTN } \\
\text { PIMP }\end{array}$ & 5 & & 1 & 4.043 & & & 2 & 8.355 & 1 & 32.603 \\
\hline RAD & 4 & 319,415 & 2 & $\begin{array}{r}2,082 \\
397,064\end{array}$ & 4 & 800 & 1 & 1.400 & 1 & 1.100 \\
\hline & & & & & $\begin{array}{l}1 \\
1\end{array}$ & $\begin{array}{r}17.251 \\
784\end{array}$ & 1 & 25.270 & & \\
\hline $\begin{array}{l}\text { SECURITY } \\
\text { SHOP }\end{array}$ & $\begin{array}{l}2 \\
6\end{array}$ & $\begin{array}{l}28.125 \\
34.279\end{array}$ & $\begin{array}{r}2 \\
10\end{array}$ & $\begin{array}{l}15.344 \\
94.222\end{array}$ & 3 & 193 & $\begin{array}{l}9 \\
1\end{array}$ & $\begin{array}{l}376 \\
960\end{array}$ & 9 & 20.548 \\
\hline $\begin{array}{l}\text { SHOP-AIR } \\
\text { SHOP-ELC } \\
\text { SHOP-HVY }\end{array}$ & $\begin{array}{l}2 \\
1 \\
1\end{array}$ & $\begin{array}{r}387 \\
343.762 \\
6.876\end{array}$ & $\begin{array}{l}2 \\
1\end{array}$ & $\begin{array}{r}3.272 \\
18.990\end{array}$ & 1 & 54 & & & & \\
\hline SHOP-HV & & & & & & & & & 2 & 45,126 \\
\hline $\begin{array}{l}\text { SHOP-UPN } \\
\text { SIMULTR }\end{array}$ & 1 & 879 & 3 & 13.265 & 4 & 8,664 & 1 & 5,520 & $\begin{array}{l}2 \\
1\end{array}$ & $\begin{array}{r}3,344 \\
20,100\end{array}$ \\
\hline STA-UTL & 1 & 379 & & & & & & & & \\
\hline $\begin{array}{l}\text { STOR-UH } \\
\text { TRAINING }\end{array}$ & 3 & 9.711 & $\begin{array}{l}7 \\
2\end{array}$ & $\begin{array}{l}18.741 \\
25.956\end{array}$ & 2 & 2.129 & $\begin{array}{l}1 \\
4 \\
2\end{array}$ & $\begin{array}{r}286 \\
7.212 \\
2.400\end{array}$ & 19 & 78,860 \\
\hline $\begin{array}{l}\text { WHS } \\
\text { WHS-CLO }\end{array}$ & 9 & $1,176,365$ & $\begin{array}{l}3 \\
1 \\
\end{array}$ & $\begin{array}{r}38.035 \\
6.375 \\
\end{array}$ & 1 & 32,620 & & & 1 & 7,500 \\
\hline TOTAL & 60 & $2,916,290$ & 243 & $1,883,848$ & 183 & 482.703 & 33 & 269.748 & 58 & 459,985 \\
\hline
\end{tabular}


In addition to the permanent housing, there is a mobile home park with space for 50 units. Heat and hot water are provided by bottled propane. The mobile homes are not considered candidates for energy conservation or fuelswitching measures in this assessment because they are neither owned by nor permanently situated on the base. The mobile homes are, however, included in the baseline analysis since their energy use must be accounted for to avoid biasing the baseline estimates of energy use in other buildings.

Table 1.5 enumerates all of the distinct permanent family housing unit configurations and lists number of units, unit floor area, and total floor area for each floor plan. Note that the term "unit" in the table heading refers to a single-dwelling unit while a "building" generally contains multiple-dwelling units.

\subsubsection{Central Thermal System Characterization}

Steam is distributed to approximately 250 buildings on the base by a predominantly underground network of insulated pipe and conduit. There are about 6 miles of buried pipe and less than 1 mile of above-ground pipe. Significant steam leakage has been reported.

Steam is supplied from two sources: the Oneida County Public Works Department operates a waste energy recovery (refuse-burning boiler) plant (OCPWD-WERP), which came on line in 1984, and a new central steam plant constructed in 1985. The Griffiss AFB steam plant is located on the railroad spur. The boilers are fueled by bituminous and anthracite coals as primary fuels.

The Griffiss AFB steam plant is closed from May 15 to September 15 each year. During this period the OCPWD-WERP is the distribution system's sole source of steam. The distribution branches that serve buildings in the main commercial area are shut down and the only buildings that receive steam are the dorms and the hospital. Buildings served by the parts of the distribution system that are shut down in summer have to revert to electric or oil-fired water heaters for domestic water heating. 
IABLE 1.5. Floor Area Data for Each Distinct Dwelling Unit and Building Floor Plan

\begin{tabular}{|c|c|c|c|c|c|c|c|}
\hline Skyline Bldg. Type & $\begin{array}{l}\text { Bldg. } \\
\text { Sq. Ft. }\end{array}$ & $\begin{array}{l}\text { Unit } \\
\text { Sg. Ft. }\end{array}$ & $\begin{array}{c}\text { Plan } \\
\text { Number (s) }\end{array}$ & $\begin{array}{l}\text { No. of } \\
\text { Bedrooms }\end{array}$ & $\begin{array}{l}\text { No. of } \\
\text { Bldgs. }\end{array}$ & $\begin{array}{l}\text { No. of } \\
\text { Units }\end{array}$ & $\begin{array}{l}\text { Sq. Ft. } \\
\text { Total }\end{array}$ \\
\hline Single Family & 2.756 & 2.756 & $S L-15$ & 4 & 1 & 1 & 2.756 \\
\hline Single Family & 1.642 & 1,642 & $S L-13.14$ & 4 & 3 & 3 & 4,926 \\
\hline Single Family & 2,452 & 2.452 & $S L-12$ & 4 & 1 & 1 & 2.452 \\
\hline Single Family & 1.231 & 1.231 & $S L-8,9,10,11$ & 3 & 33 & 33 & 40,623 \\
\hline Single Fantly & 2,462 & 2.462 & $S L-7$ & 3 & 18 & 18 & 44.316 \\
\hline Duplex & 2,290 & 1.145 & $S L-5,6$ & 3 & 41 & 82 & 93,890 \\
\hline Duplex & 3,567 & 1.784 & $S L-5 A$ & 3 & 10 & 20 & 35,670 \\
\hline Duplex & 1.868 & 934 & $S L-3,4$ & 2 & 13 & 26 & 24,284 \\
\hline 6-Plex & 9,611 & 1.602 & $S L-2$ & 3 & 28 & 168 & 269.108 \\
\hline 6-Plex & 8,436 & 1.406 & $S L-1$ & 2 & 18 & 108 & 151.848 \\
\hline Skyline Totals: & & & & & 166 & 460 & 669,873 \\
\hline \multicolumn{8}{|l|}{ Woodhaven Bldg. Type } \\
\hline Single Family & 2.117 & 2,117 & WH-7 & 4 & 2 & 2 & 4,234 \\
\hline Single Family & 1,586 & 1.586 & WH-6 & 4 & 16 & 16 & 25.376 \\
\hline Single Family & 1,534 & 1,534 & WH-5 & 3 & 14 & 14 & 21.476 \\
\hline Single Family & 1.476 & 1.476 & $W H-4$ & 4 & 12 & 12 & 17.712 \\
\hline Single Family & 1.476 & 1.476 & WH-3 & 3 & 6 & 6 & 8,856 \\
\hline Duplex & 3,198 & 1.599 & WH-6A & 4 & 3 & 6 & 9,594 \\
\hline Duplex & 3,068 & 1,534 & $W H-5 A$ & 3 & 4 & 8 & 12,272 \\
\hline Duplex & 2.952 & 1.476 & $W H-4 A$ & 4 & 11 & 22 & 32,472 \\
\hline Duplex & 2,952 & 1.476 & $W H-3 A$ & 3 & 10 & 20 & 29.520 \\
\hline Duplex & 2.112 & 1.056 & WH-1 & 3 & 48 & 96 & 101.376 \\
\hline 4-Plex & 4.528 & 1.132 & $W H-182$ & $384 \star$ & 12 & 48 & 54,336 \\
\hline 4-Plex & 4.224 & 1,056 & WH-1 & 3 & 5 & 20 & 21.120 \\
\hline Woodhaven Totals: & & & & & 143 & 270 & 338,344 \\
\hline \multicolumn{6}{|l|}{ Farmhouse Bldg. No. } & \multicolumn{2}{|c|}{ These 4-plexes are half 3-bedroom units and half 4-bedroom units. } \\
\hline 231 & 2.471 & & & 3 & 1 & 1 & 2.471 \\
\hline 232 & 3.470 & & & 3 & 1 & 1 & 3,470 \\
\hline 480 & 3.189 & & & 3 & 1 & 1 & 3,189 \\
\hline 880 & 3,577 & & & 3 & 1 & 1 & 3.577 \\
\hline 883 & 3.160 & & & 4 & 1 & 1 & 3,160 \\
\hline Farmhouse Totals: & & & & & 5 & 5 & 15,867 \\
\hline Grand Total & & & & & 314 & 735 & 1.024 .074 \\
\hline
\end{tabular}




\subsubsection{Utility Characterization}

Utilities at the site include electricity, centrally distributed steam, water, sewer, and fossil fuels, including some natural gas distribution.

Steam serves all but a few (-95\%) of the commercial buildings. The distribution pressure ranges from $100 \mathrm{psig}$ in summer to $150 \mathrm{psig}$ in winter. Each building on the loop has a heat exchanger for space heating and a heat exchanger for domestic water heating. Modulating valves control the flow of steam to control temperature on the load side. The loop is fed by the onsite plant (75\%) and municipal plant (25\%) described previously in Section 1.2.3.

Electrical service is provided by Niagara Mohawk Power Company to the substation located at the intersection of Ellsworth Road and Wright Drive. Three 5,000 kVA-main transformers and one 5,000-kVA ratio bank are currently in operation. The site owns and operates the substation, including the main transformers. Power enters on 115-kV delta circuits. Prior to 1984, all power was dropped to $4,160 / 2,400$ volts by three auto-tap changing transformers and distributed on 10 feeder circuits designated 1-9 and 11 . One of the three main transformers was removed from service in 1985 when an apparent electrical malfunction caused overheating. A fourth main transformer was added in 1984 to provide the new boiler plant with power at $13.2 / 7.6 \mathrm{kV}$. A ratio bank that drops $13.2 \mathrm{kV}$ delta power to 4,160/2,400-volt wye power was installed in 1985 to pick up the three feeders previously fed by the failed main transformer. Power factor correction is provided by capacitor banks connected to the transformers as follows: transformer 2 (feeders $3 \& 4$ ), 500 kVAR; transformer 3 (feeders 6-11), 300 kVAR; and ratio bank (feeders 1, 2, \& 5), 600 kVAR.

The feeder circuits are all 4-wire wye circuits wired with various conductor sizes. Feeders 10, 12, and 13 use $366 \mathrm{MCM}$ (thousand circular mills) aluminum conductors. The rest of the overhead lines are wired with conductors ranging in size from $\# 2$ to $\# 00$ gage wire. The underground lines use $\# 0000$ gage wire. The feeders are predominantly overhead lines.

There are currently 13 feeders serving Griffiss AFB. Feeders 1 through 4 cover most of the major commercial and industrial areas of the base, including most of the Rome Labs and the weapon storage area. Feeder 5 covers the 
barracks, dining facilities, chapel, and recreational buildings. Feeder 6 covers the Strategic Air Command area, except for building 796, the flight simulator, which is the only building on feeder 7 . Feeder 8 serves the Skyline housing area. Feeder 9 serves the Woodhaven housing area and the hospital. Feeder 10 is a cross-feed, which is generally open, to the B112 substation. Feeder 11 has only one bujlding, building 3, which is part of the Rome Labs. Feeders 12 and 13 serve the central steam plant and related buildings.

The distribution of aggregate building floor area by building type and feeder is given in Table 1.6. Note that some building types are further disaggregated. This disaggregation was made when the aggregate energy-use intensity for the building type appeared to differ signiticantly among feeders (see Section 9).

Note that the sum of floor areas in Table 1.6 Joes not match the sums in Tables 1.3 and 1.4 exactly because Tables 1.3 and 1.4 include some offsite buildings ( 1200 and 1300 ), some buildings directly serviced by Niagara Mohawk feeders (6242 and 6310), and some other buildings that could not be identified with a main substation feeder $(5025,5372$ and 6323). Some buildings in the last group may have been demolished and are presumed to have negligible electric energy consumption in any case.

Many of the transformers will be replaced in the distribution system upgrade that is currently in progress. Table 1.7 describes the transformers in terms of number, KVA, and phase. The data in the table are based on the transformer schedule provided in the distribution system upgrade design of 1991 and the list of PCB-bearing transformers as of January 1992. Note tiat three areas will continue to be served by 4,160-volt distribution 1 ines. The Skyline housing area (Feeder 8 ) will be supplied with 4,160-V power from a new transformer that will replace transformer T-3 (manufactured circa. 1940; rewound 1972) in the main substation. The new transformer will have a 115-kV delta primary and 4,160/2,400V wye secondary but may have a smaller kVA rating than T-3. The Woodhaven housing area and nearby dormitories (Feeder 9) will 
TABLE 1.6. Floor Area $\left(\mathrm{ft}^{2}\right)$ by Building Type and Electric Distribution Feed Based on Dominant Whole-Building Function

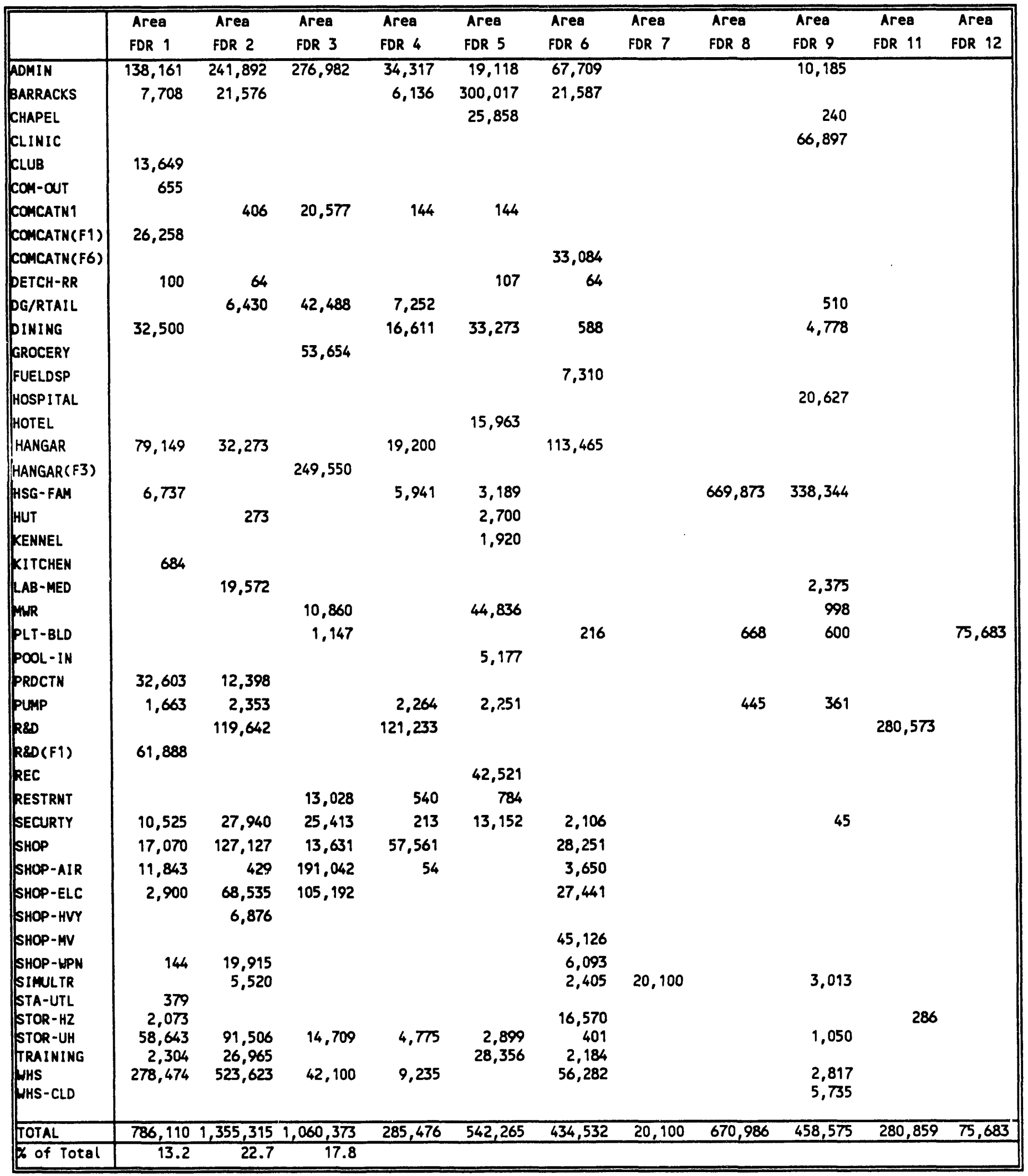


IABLE 1.7. Transformer Schedule for Distribution System Upgrade

\begin{tabular}{|c|c|c|c|c|c|}
\hline No. & Phase & $\begin{array}{l}\text { Primary } \\
\text { Voltage }\end{array}$ & $\begin{array}{l}\text { Size } \\
\text { (kVA) }\end{array}$ & Count & $\begin{array}{l}\text { Total } \\
\text { kVA }\end{array}$ \\
\hline $\begin{array}{l}1 \\
1 \\
1 \\
1\end{array}$ & $\begin{array}{l}1 \\
1 \\
1 \\
1\end{array}$ & $\begin{array}{r}4,160 \\
4,160 \\
4,160 \\
4,160\end{array}$ & $\begin{array}{r}10 \\
15 \\
25 \\
37.5 \\
\end{array}$ & $\begin{array}{r}2 \\
1 \\
86 \\
14\end{array}$ & $\begin{array}{r}20 \\
15 \\
2,150 \\
525 \\
\end{array}$ \\
\hline$\overline{1}$ & 1 & 13,200 & 7 & 1 & 7 \\
\hline 1 & 1 & 13,200 & 10 & 1 & 10 \\
\hline 1 & 1 & 13,200 & $\begin{array}{l}15 \\
25\end{array}$ & $\begin{array}{r}4 \\
35\end{array}$ & $\begin{array}{r}60 \\
875\end{array}$ \\
\hline 1 & 1 & 13,200 & 37.5 & 2 & 75 \\
\hline 1 & $\mathrm{i}$ & 13,200 & 50 & 9 & 450 \\
\hline 1 & 1 & 13,200 & 75 & 1 & 75 \\
\hline 1 & 1 & 13,200 & 100 & 2 & 200 \\
\hline 1 & 1 & 13,200 & 167 & 2 & 334 \\
\hline$\overline{1}$ & 3 & 13,200 & 45 & 3 & 135 \\
\hline 1 & 3 & 13,200 & 75 & 5 & 375 \\
\hline 1 & 3 & 13,200 & 112.5 & 1 & 113 \\
\hline 1 & 3 & 13,200 & 150 & 21 & 3,150 \\
\hline 1 & 3 & 13,200 & 225 & 19 & 4,275 \\
\hline 1 & 3 & 13,200 & 300 & 16 & 4,800 \\
\hline 1 & 3 & 13,200 & 450 & 7 & 3,150 \\
\hline 1 & 3 & 13,200 & 500 & 14 & 7,000 \\
\hline 1 & 3 & 13,200 & 600 & 1 & 600 \\
\hline 1 & 3 & 13,200 & 750 & 8 & 6,000 \\
\hline 1 & 3 & 13,200 & 1,000 & 4 & 4,000 \\
\hline 1 & 3 & 13,200 & 1,500 & 3 & 4,500 \\
\hline 3 & 1 & 4,160 & 25 & 3 & \\
\hline 3 & 1 & 4,160 & 600 & 3 & 1,800 \\
\hline$\overline{3}$ & $\overline{1}$ & 13,200 & 15 & 3 & 45 \\
\hline 3 & 1 & 13,200 & 25 & 93 & 2,325 \\
\hline 3 & 1 & 13,200 & 37.5 & 36 & 1,350 \\
\hline 3 & 1 & 13,200 & 50 & 45 & 2,250 \\
\hline 3 & 1 & 13,200 & 75 & 12 & \\
\hline 3 & 1 & 13,200 & 100 & 9 & 900 \\
\hline 3 & 1 & & 167 & 3 & 500 \\
\hline
\end{tabular}

be served by a 13-kV to 4,160-V ratio bank. Building 100, the airfield, and the weapon storage areas (Feeder 2) will be served by another 13-kV to 4,160-V ratio bank.

Domestic water is supplied by the municipal water system of Rome, New York. Annual volumes for the fiscal years ia88 through 1991 were 417,698, $346,302,381,751$, and $371,848 \mathrm{kGal}$, respectively. A 500,000-gallon on-grade 
tank, two 500-gpm pumps, and three 1000-gpm pumps are located at Building 210. The tank and booster pumps are designed to maintain pressure and reserve water during intensive flow through fire hydrants.

The municipal sewage system of Rome, New York, processes effluent from the base's sewage collection system. The sewage collection network at Griffiss AFB consists of seven small lift stations which have an aggregate connected pump load (lead pumps only) of about $90 \mathrm{hp}(125 \mathrm{~kW})$. It is estimated that the sewage collection system used less than 200,000 kWh in 1991. It appears from Form 242 records that Griffiss AFB pays a flat rate for sewage based on 208,050 $\mathrm{kGal}$ per year. Table 1.8 summarizes the sewage $1 \mathrm{ift}$ pump characteristics.

Streetlighting in the Woodhaven area is provided by 31 pole-mounted, 400-watt, mercury vapor streetlamps. The Skyline area is illuminated by 48 pole-mounted, incandescent ( 6.6 amp series-type) streetlamps. The trailer park is illuminated by 25 pole-mounted, 250-watt, HPS streetlamps. Streets in other parts of the base are illuminated by 79 HPS streetlamps, 51 series incandescent lamps, and 24 mercury vapor lamps. There are 477 (mostly HPS) lamps associated with aircraft security applications and 351 pole-mounted lamps serving other exterior security lighting applications.

TABLE 1.8. Sewer Lift Pump Inventory

\begin{tabular}{|r|lcccc||}
\hline Bldg. No. & \multicolumn{1}{|c}{ Description } & Qty. & Size (hp) & GPM & Lift (ft) \\
\hline 3027 & Woodhaven Housing Area & 2 & 5 & 250 & 30 \\
793 & SAC Alert Area & 2 & 5 & 300 & NA \\
& Ind. Waste Facility & NA & NA & 200 & NA \\
31 & S. of Bldg 7 & 2 & 5 & 300 & NA \\
2645 & Skyline Housing Area & 2 & 29 & 500 & 75 \\
21 & S. of Bldg 2 & 2 & 40 & 1000 & 70 \\
890 & New Club & 2 & 5 & NA & NA \\
\hline NA: Not Avail able & & &
\end{tabular}


The total streetlighting load, including ballasts, is about $46 \mathrm{~kW}$, corresponding to an annual energy use of about $202,000 \mathrm{kWh}$. The lamp circuits are controlled predominantly by photocells.

The connected load of quartz and HPS runway, apron, and perimeter lights is $220 \mathrm{~kW}$ with an annual energy use of about $958,000 \mathrm{kWh}$.

The connected load of incandescent runway and taxiway lights is $72.5 \mathrm{~kW}$ with an annual energy use of about $160,000 \mathrm{kWh}$. These lights are switched on by the tower whenever aircraft are taking off or landing from dawn to dusk or during precipitation or heavy overcast. Aircraft operate on weekends as well as weekdays.

The connected load of other pole-mounted area lighting is about $105 \mathrm{~kW}$ with an annual energy use of about $461,000 \mathrm{kWh}$.

Details of the exterior lighting inventory are documented in Table 1.9. 
TABLE 1.9. Street and Exterior Light Inventory

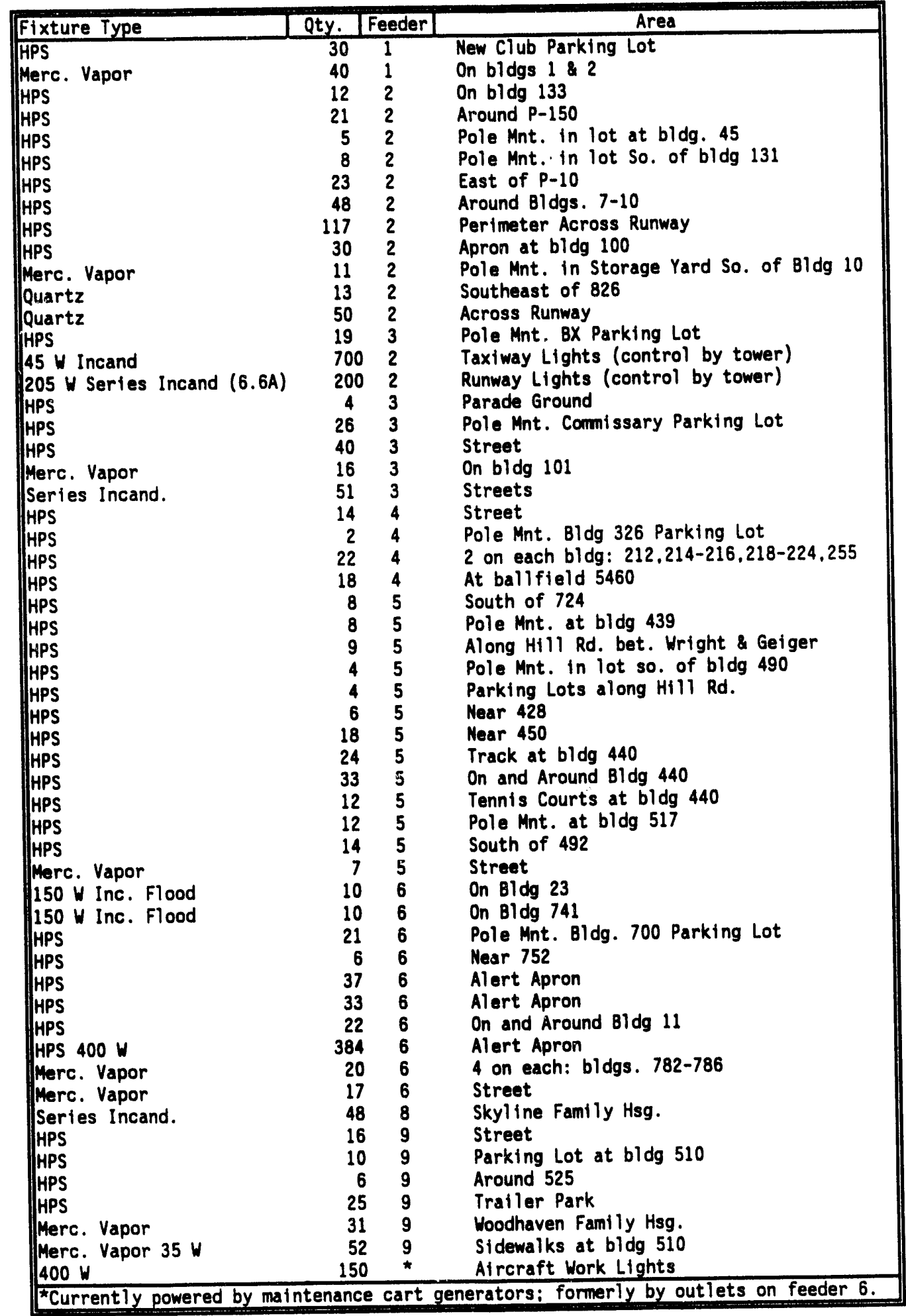




\subsection{ENERGY SOURCE CHARACTERISTICS}

This section describes the sources of energy at Griffiss AFB, how energy is delivered to the base, and what it costs.

Table 2.1 summarizes typical yearly consumption for each form of energy. The total consumption values are based on the usage values chosen for analysis in this report as typical current yearly usage. In some cases the numbers are aggregations of yearly or billing consumption amounts and do not exactly match current or past consumption values or values used in Griffiss AFB energy reporting. The numbers presented are considered representative of normal base operational energy consumption.

Both electric and non-electric supplies are described below to show the relative importance of the energy sources. The information on non-electric supplies has been intentionally limited to very basic summary data because the scope of the Griffiss AFB conservation assessment is limited to electric loads.

IABLE_2.1. Typical Yearly Energy Consumption for FY 1990 at Griffiss AFB (from DEIS report)

\begin{tabular}{|c|c|c|}
\hline $\begin{array}{ll}\text { Energy } & \text { Yearly } \\
\text { Source } & \text { Total } \\
\end{array}$ & $\begin{array}{l}\text { Year } \\
\text { Total }\left(M B t u^{a}\right)\end{array}$ & $\begin{array}{l}\text { Percent } \\
\text { of Total } \\
\end{array}$ \\
\hline 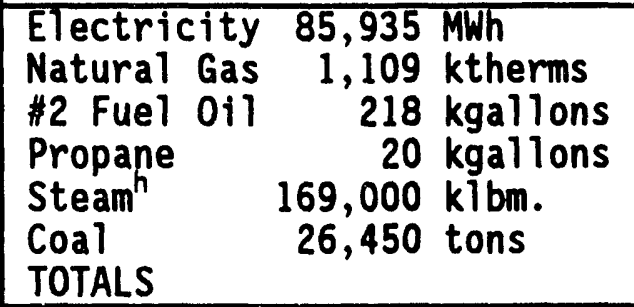 & $\begin{array}{r}293,211^{\mathrm{b}} \\
110,990^{\mathrm{c}} \\
30,271^{\mathrm{d}} \\
1,818^{\mathrm{e}} \\
168,580^{\mathrm{f}} \\
648,095^{\mathrm{g}} \\
1,252,965\end{array}$ & $\begin{array}{r}22.5 \\
9.0 \\
2.4 \\
0.2 \\
13.7 \\
52.2 \\
100.00\end{array}$ \\
\hline $\begin{array}{l}\text { Notes: } \\
\text { (a) } 1,000,000 \mathrm{Btu} / \mathrm{MBtu} \\
\text { (b) } 3,413 \mathrm{Btu} / \mathrm{kWh} \\
\text { (c) } 100,000 \mathrm{Btu} / \text { therm; } 1,050 \\
\text { (d) } 0.1388 \mathrm{MBtu} / \mathrm{gal} \\
\text { (e) } 0.0913 \mathrm{MBtu} / \mathrm{gal} \\
\text { (f) } 1,000 \mathrm{Btu} / \mathrm{bm} \\
\text { (g) } 24.5 \mathrm{MBtu} / \mathrm{ton} \\
\text { (h) Steam source is energy pu } \\
\text { OCPWD-WERP steam plant. }\end{array}$ & $t u / f t^{3}$ & \\
\hline
\end{tabular}




\subsection{ELECTRIC SUPPLY SOURCE DESCRIPTION}

The main electrical service is provided by Niagara Mohawk on one main 115-kV delta loop that can feed from Rome, NY, or Boonesville, NY. Billing records for a typical year (FY 1991) indicate on-post use of 86,000 MWh at an aggregate cost of 6.0 cents/kWh, for a total annual cost of $\$ 5,200,000$. Electricity is billed under a time-of-use rate structure designated SC-3A. The on-peak period is from $8 \mathrm{a} . \mathrm{m}$. to $10 \mathrm{p} . \mathrm{m}$. weekdays except holidays. The holidays include New Year's Day, Memorial Day, Independence Day, Labor Day, Thanksgiving, and Christmas. The rate in effect in 1990 was $\$ 0.04834$ per onpeak kWh, $\$ 0.03456$ per off-peak $k W h, \$ 4.69$ per on-peak $k W$, and $\$ 0.76$ per excess KVAR. The rate that has been in effect since 1 July $1991^{(a)}$ is $\$ 0.05859$ per on-peak $\mathrm{kWh}, \$ 0.04382$ per off-peak $\mathrm{kWh}, \$ 5.51$ per on-peak $\mathrm{kW}$, and \$0.83 per excess KVAR. Excess reactive demand for a given month is defined as peak (15-minute) KVAR minus one-third the on-peak kW demand.

There are five minor Niagara Mohawk feeds that are separately billed and metered. Billing records for a typical year (FY 1991) indicate use of 332 MWh at an average cost of $9.11 \mathrm{cents} / \mathrm{kWh}$ for the secondary voltage off-base feeds. Electricity is billed under the rate structure designated Service Class $2 /$ demand. The current rate is $\$ 0.06509$ per $\mathrm{kWh}$ plus $\$ 7.36$ per $\mathrm{KW}$-month plus $\$ 19.17$ per month. The primary voltage service to the substation at Building 112 supplied 123 MWh in FY 1991, which is much lower than the 9,777 MWh supplied in FY 1988 and the 3,781 MWh supplied in FY 1989.

There are 32 diesel generators at the site with $20 \mathrm{kVA}$ or greater capacity. The generators of $500 \mathrm{~kW}$ or greater capacity have an aggregate capacity of $2685 \mathrm{~kW}$. The generators of 100 to $499 \mathrm{~kW}$ capacity have an aggregate capacity of $2525 \mathrm{~kW}$. The generators of 20 to $99 \mathrm{KW}$ capacity have an aggregate capacity of $610 \mathrm{~kW}$. Generators are currently used to provide emergency power for critical buildings and for sewage lift stations and other critical utility functions. The generators are listed in Table 2.2.

(a) New York State Public Service Commission. Case Numbers 89-E-152 and 29327 et al. Dated June 28, 1991. 
IABLE 2.2. Gasoline and Diesel Geyerators of 20 kVA or Greater Capacity

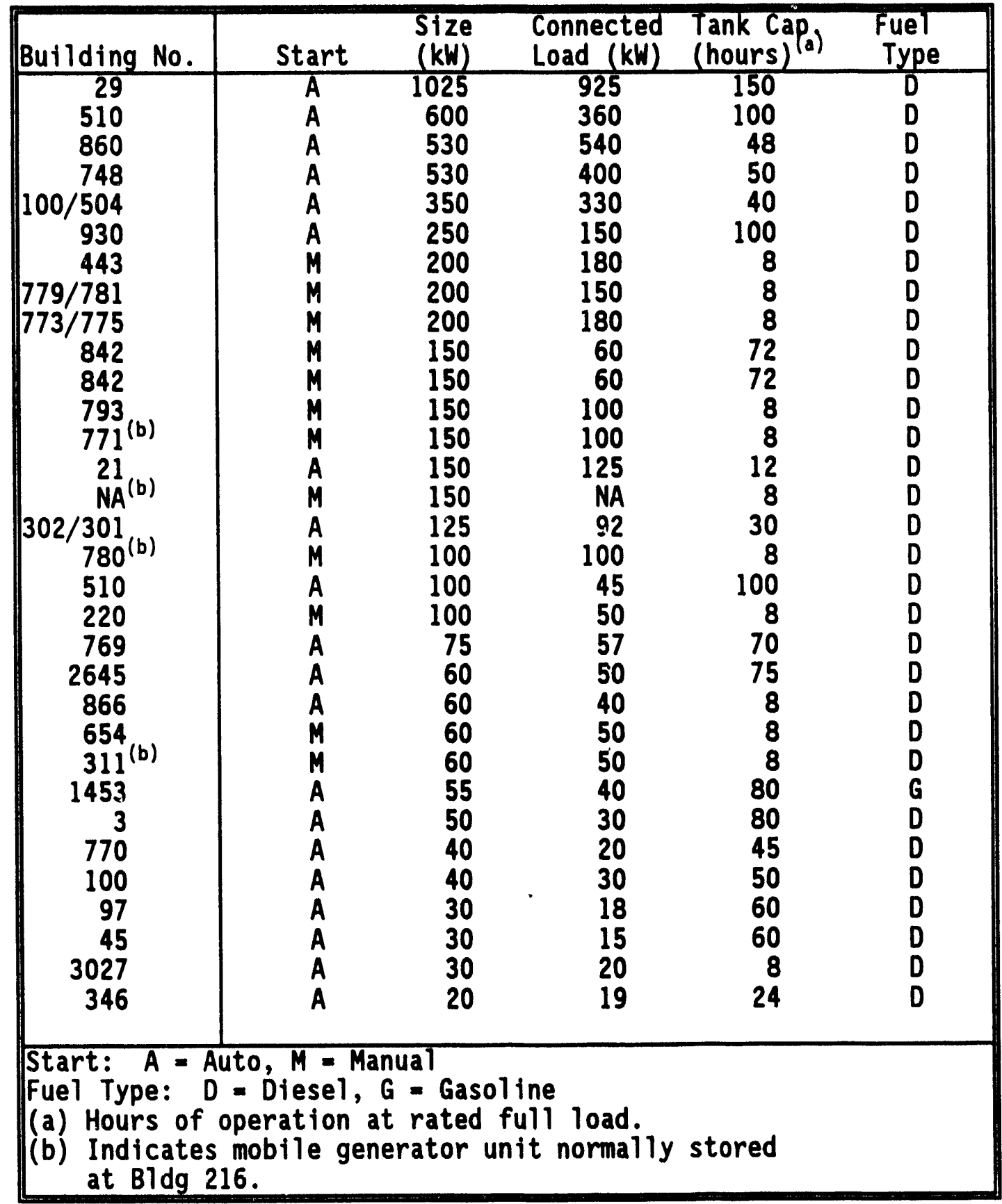




\subsection{MATURAL GAS SUPPLY SOURCE DESCRIPTION .}

Niagara Mohawk supplies natural gas to Griffiss AFB under rate schedule SC3. Gas metering and billing are performed by Niagara Mohawk. The points of entry for natural gas are meterhouse buildings 2000 and 3000 where 6 -inch high-pressure main lines distribute gas to the family housing areas. Lowpressure distribution lines are reduced from $12 \mathrm{in}$. to $10 \mathrm{in}$. and $6 \mathrm{in}$. lines and eventually to $4 \mathrm{in.,} 2 \mathrm{in}$, and $1.5 \mathrm{in}$. service lines.

Natural gas consumption in FY 1990 was $1,110,000$ therms $(110,000 \mathrm{MBtu})$ at an average cost of $\$ 0.537 /$ therm, for a total cost of $\$ 596,000$. Natural gas represents $9.0 \%$ of the non-transportation energy use on the base.

The new club, completed in early FY 1992, will use natural gas for heating, so the total load for Griffiss AFB can be expected to increase in FY 1992.

\subsection{OIL SUPPLY SOURCE DESCRIPTION}

In FY 1990, 218,000 gallons of \#2 fuel o11 $(30,271 \mathrm{MBtu})$ was used at Griffiss AFB at an average price of $\$ 0.56 / \mathrm{gal}$ ion $(\$ 4.03 / \mathrm{MBtu})$, for an annual cost of $\$ 122,100$. Fuel oil use represents $2.4 \%$ of the non-transportation energy used on the base.

\subsection{PROPANE SUPPLY SOURCE DESCRIPTION}

In FY 1990, 19,800 gallons of propane (1820 MBtu) was used at Griffiss AFB at an average price of $\$ 0.65 /$ gallon ( $\$ 5.90 / \mathrm{MBtu}$ ), for an annual cost of $\$ 12,900$. Propane is used for space and water heating and cooking in the mobile home park. Propane represents $0.15 \%$ of the non-transportation energy used on the base.

\subsection{COAL SUPPLY SOURCE DESCRIPTION}

Coal is burned to produce steam in the main steam plant. Annual coal use is 26,450 tons $(648,095 \mathrm{MBtu})$ at an average price of $\$ 40.92 /$ ton $(\$ 1.67 / \mathrm{MBtu})$, for a total cost of $\$ 1,080,000$ per year. Coal represents $52.2 \%$ of the non-transportation energy used on the base. 


\subsection{PURCHASED STEAM SOURCE DESCRIPTION}

The Oneida County Public Works Department feeds steam into the main distribution 100p. In FY 1990, OCPWD delivered 168,500 MBtu of steam to Griffiss AFB. The average fuel charge was $\$ 8.25$ per MBtu (\$0.0095 per $1 \mathrm{bm}$ ), and the average capacity charge was nearly $\$ 115,600$ per month. The total charge for steam in FY 1990 was $\$ 1,387,000$. Purchased steam represented $13.7 \%$ of the non-transportation energy use on the base. 


\subsection{ELECTRIC CONSUMPTION}

Metered electric use data form the primary basis for baseline energy-use intensity estimates. The data from existing meters and the data obtained specifically for this project by monitoring equipment installed by PNL at the site are summarized and discussed in this section.

\subsection{METERING AND DATA SUMMARY}

There were four sources of electric metering and consumption data at Griffiss AFB: substation meter logs, utility company meter readings, meter readings from selected bulldings, and PNL substation feeder monitoring.

The substation has a set of ammeters on each feeder. These are read weekly, but the readings, being instantaneous and of low resolution, are of marginal value. Also, some of the meters are not functional.

Most of the buildings owned or occupied by agencies that are required to pay their utilities (e.g., AAFES facilities such as the Commissary and BX, and tenants, such as Rome Labs) have meters that are read monthly.

All sewage lift station pumps have hour meters but their readings are not regularly logged.

Monthly Niagara Mohawk electric billing data for service provided at the substation in FY 1989 through the present are shown below in Table 3.1. The highest summer values of demand and average load are boxed; the highest winter values are shaded. The table is split into on- and off-peak periods consistent with the Niagara Mohawk billing structure. Also included are the monthiy demand peaks, which occurred in the on-peak period in all cases, and monthly excess reactive demand numbers. These data were used to reconcile the initial estimates of energy use by building type with the actual electric consumption.

There are five electric distribution feeds into the main base other than the main substation. The loads connected to these other feed points are described in Table 3.2. The annual consumption of these loads for FY 1988 through FY 1991 are also given in the table. 
IABLE 3.1. Niagara Mohawk Electric Billing Data and Corresponding Average Loads

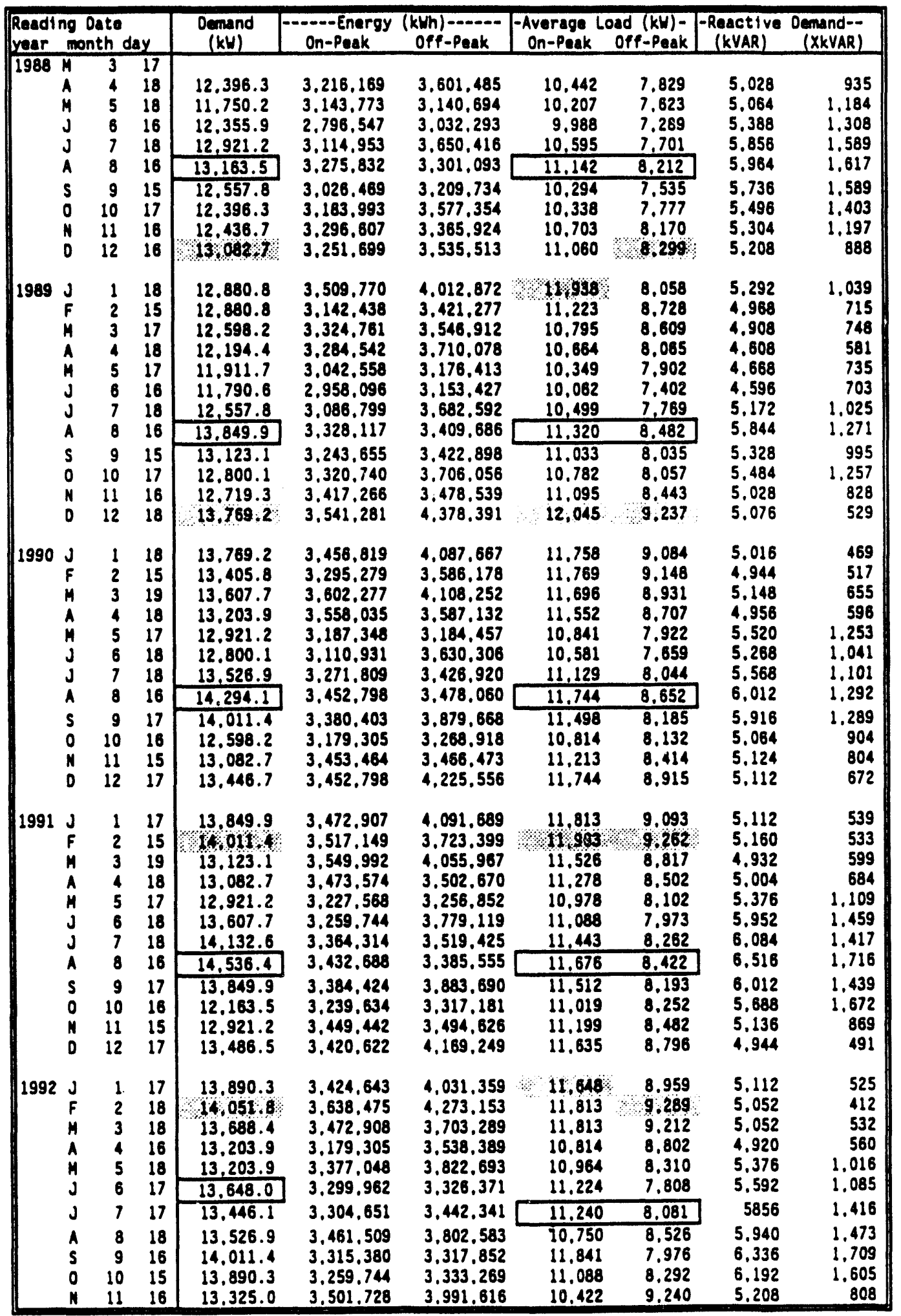


IABLE 3.2. Electric Consumption at Other Niagara Mohawk Feed Points on Main Base

\begin{tabular}{|c|c|c|c|c|c|}
\hline \multirow[b]{2}{*}{ Facility No./Location } & \multirow[b]{2}{*}{ Description } & \multicolumn{4}{|c|}{$\cdots-\cdots$ Annual Load (kWh/yr) $\cdots \cdots$} \\
\hline & & FY88 & FY89 & FY90 & FY91 \\
\hline $\begin{array}{l}277,6049 \\
802,6242, \text { S. VASI } \\
880,883,886,888 \\
896,6310 \\
112\end{array}$ & $\begin{array}{l}\text { Mohawk Gate } \\
\text { ILS } \\
2 \text { Farmhouses \& Golf Clubhouse Bldgs. } \\
\text { Base Eng. Facility and Family Camp } \\
\text { High Power Lab Substation }\end{array}$ & $\begin{array}{r}50.124 \\
62.762 \\
95.370 \\
44.930 \\
9.776 .605\end{array}$ & $\begin{array}{r}91.740 \\
84.276 \\
136.799 \\
48.228 \\
3.781 .102 \\
\end{array}$ & $\begin{array}{r}91.836 \\
85.776 \\
125.906 \\
34.998 \\
123.748\end{array}$ & $\begin{array}{r}79.032 \\
99.048 \\
94.749 \\
58.783 \\
123.073\end{array}$ \\
\hline Total & & $10,029.791$ & $4,142,145$ & 462.264 & 454.685 \\
\hline
\end{tabular}

Individual building meter readings are compiled by the Griffiss AFB exterior electric department in log books of monthly meter readings. These data were mainly from buildings that house reimbursable activities, but included some additional meters on other buildings as well. The readings were used to refine energy-use intensity estimates for building types that share feeders with one or more individually metered buildings. Consumption for each of these buildings from June 1991 to May 1992 is listed in Table 3.3. Electric meter readings are monitored for several additional buildings by the energy monitoring and control system (EMCS). The EMCS meters are listed in Table 3.4 .

Note that metered data from the primary side of a distribution transformer will include the transformer's losses (the main component of distribution loss) while data from a meter on the secondary side will not.

Beginning in October 1991, PNL conducted metering of each feeder in the Griffiss AFB substation. Fifteen-minute kilowatt, amp, and voltage readings were recorded and transmitted daily, via modem, back to PNL for analysis. These data have been compiled into average daily weekday and weekend profiles for each month of metering.

Time-of-use data from the PNL recorders were used in assessing peak shaving and demand limiting measures. Monthly feeder consumption was used in refining the energy use intensities assigned to each building type. The results of these metered data analysis activities are presented in Sections 3.2 and 9.0 of this report. 


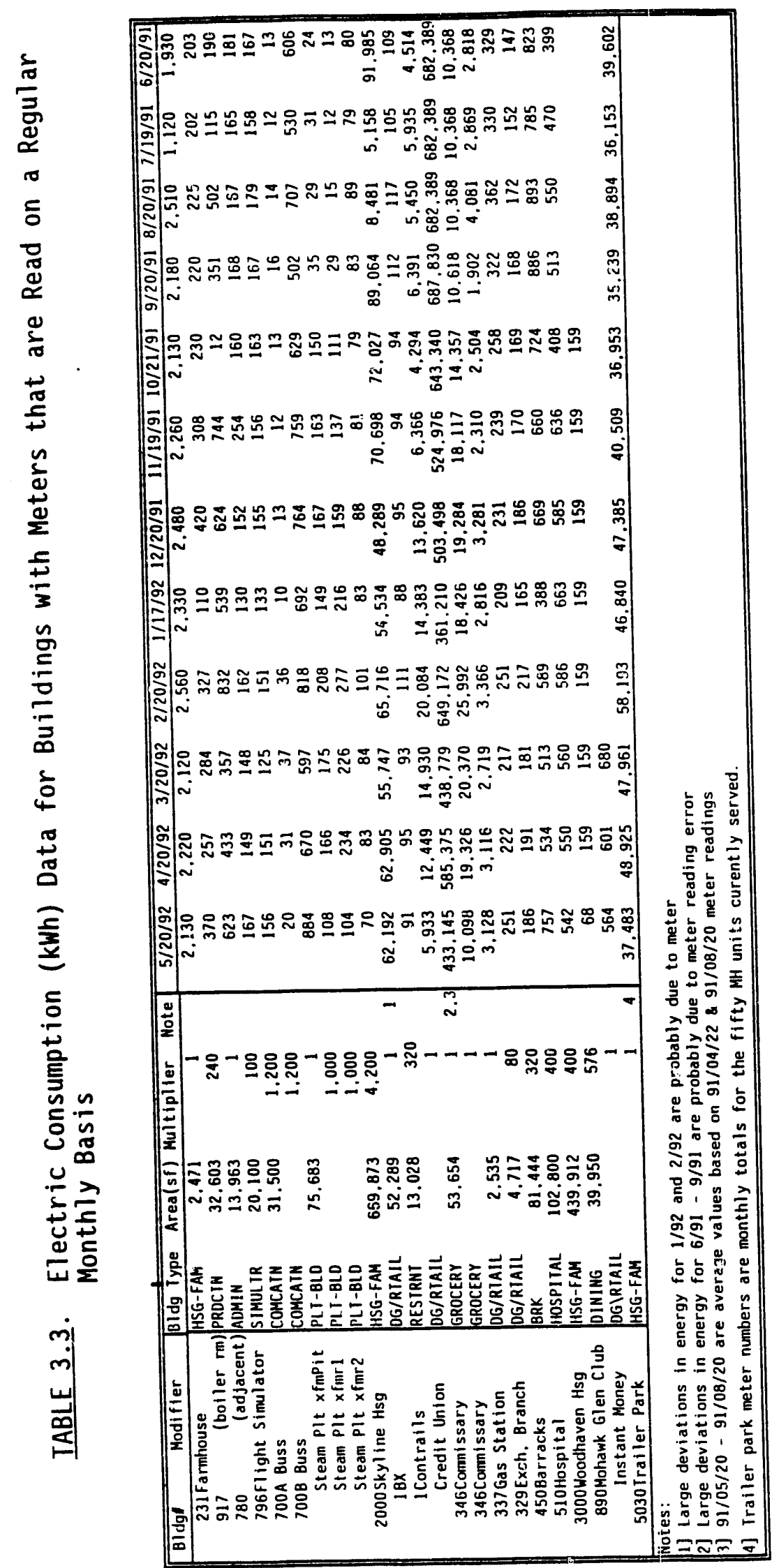


TABLE 3.4. Electric Meters Sampled by the EMCS

\begin{tabular}{||r|c|c|c|c||}
\hline BIdg. & Meter & Meter No. & Multiplier & Type \\
\hline 1 & 1 & 30810740 & 960 & DS-63 \\
\hline 1 & 2 & 9241426 & 100 & Sangamo \\
\hline 1 & 3 & 9241427 & 100 & Sangamo \\
\hline 3 & 1 & 30985396 & NA & DSMM-64 \\
\hline 100 & 1 & 17682471 & NA & CS -3 \\
\hline 100 & 2 & 9241424 & NA & HCS \\
\hline 100 & 3 & 9241425 & NA & HCS \\
\hline 101 & 1 & 21930473 & NA & DSM-3 \\
\hline 101 & 2 & 21930474 & NA & DSM-3 \\
\hline 104 & & 22026005 & NA & DS-35 \\
\hline 106 & 1 & 17638158 & 100 & CB-8 \\
\hline 106 & 2 & 17638159 & 100 & CB-8 \\
\hline- NA: not available & \\
\hline \multicolumn{5}{|l}{} \\
\hline
\end{tabular}

\subsection{ELECTRIC DEMAND SUMMARY}

Time-of-use data and load frequency distribution data are needed to assess peak-shaving and demand-limiting measures as well as the demand and time-of-use consequences of other measures.

\subsubsection{Time-of-Use Characterization}

The average weekday time-of-use profiles are plotted for each month for November 1991 through Apri1 1992 in Figure 3.1. The corresponding weekend profiles are plotted in Figure 3.2. These profiles are from the PNL metering equipment installed in the main substation.

The weekday and weekend profiles are very similar between 22:00 and 04:00 Local Standard Time (LST) because the nighttime loads consist mainly of exterior lighting, standby loads (due, e.g., to compressed air standby losses), HVAC fans and pumps that run continuously, and other equipment that runs continuously including many computers, controllers, and plug-in appliances. The weekend load is 100 to $800 \mathrm{~kW}$ lower in this period due in part to equipment that is automatically or manually shut off on weekends and in part to reduced night shift activity. 


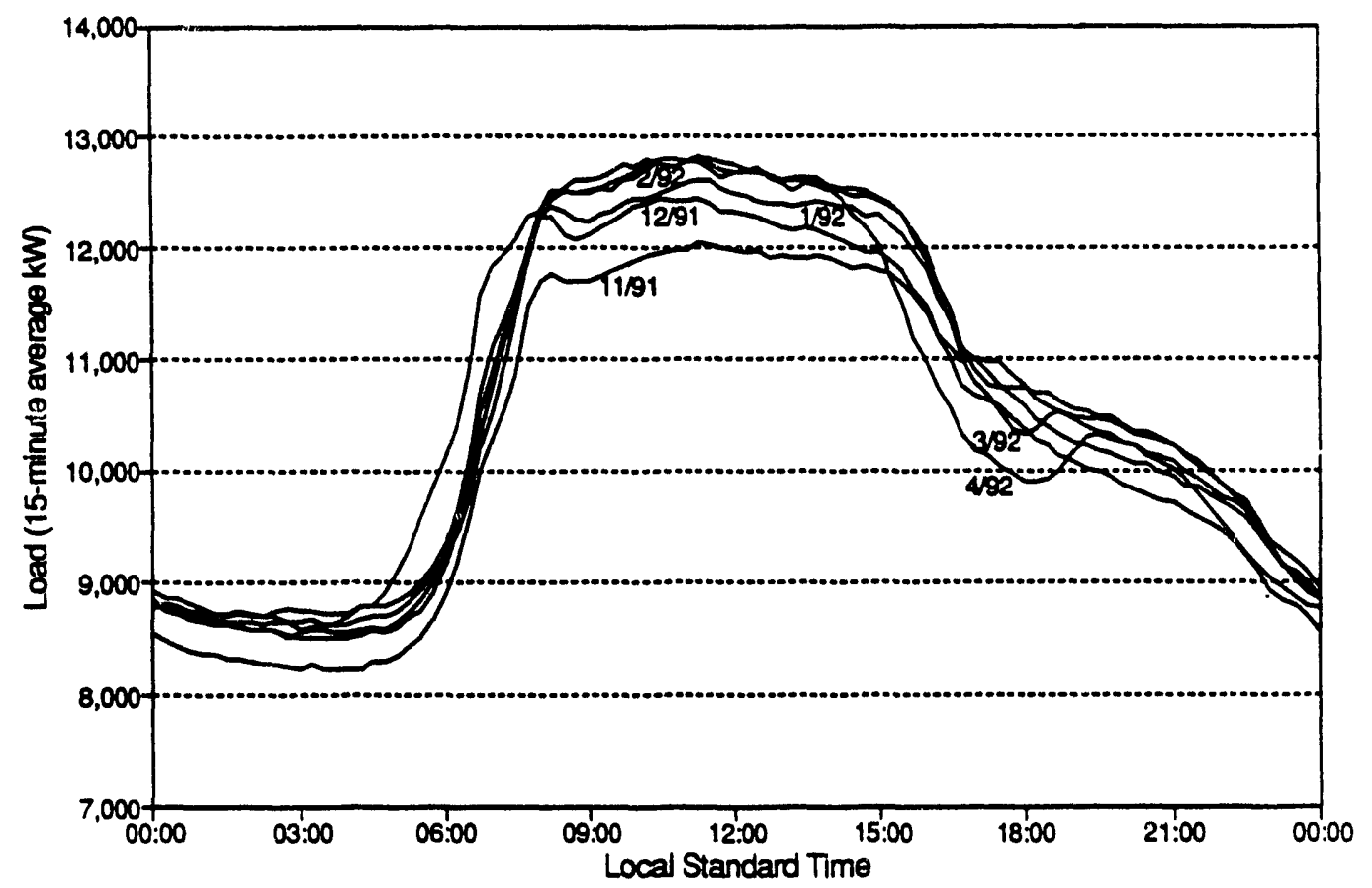

FIGURE 3.1. Monthly Average Weekday Electric Load Profiles

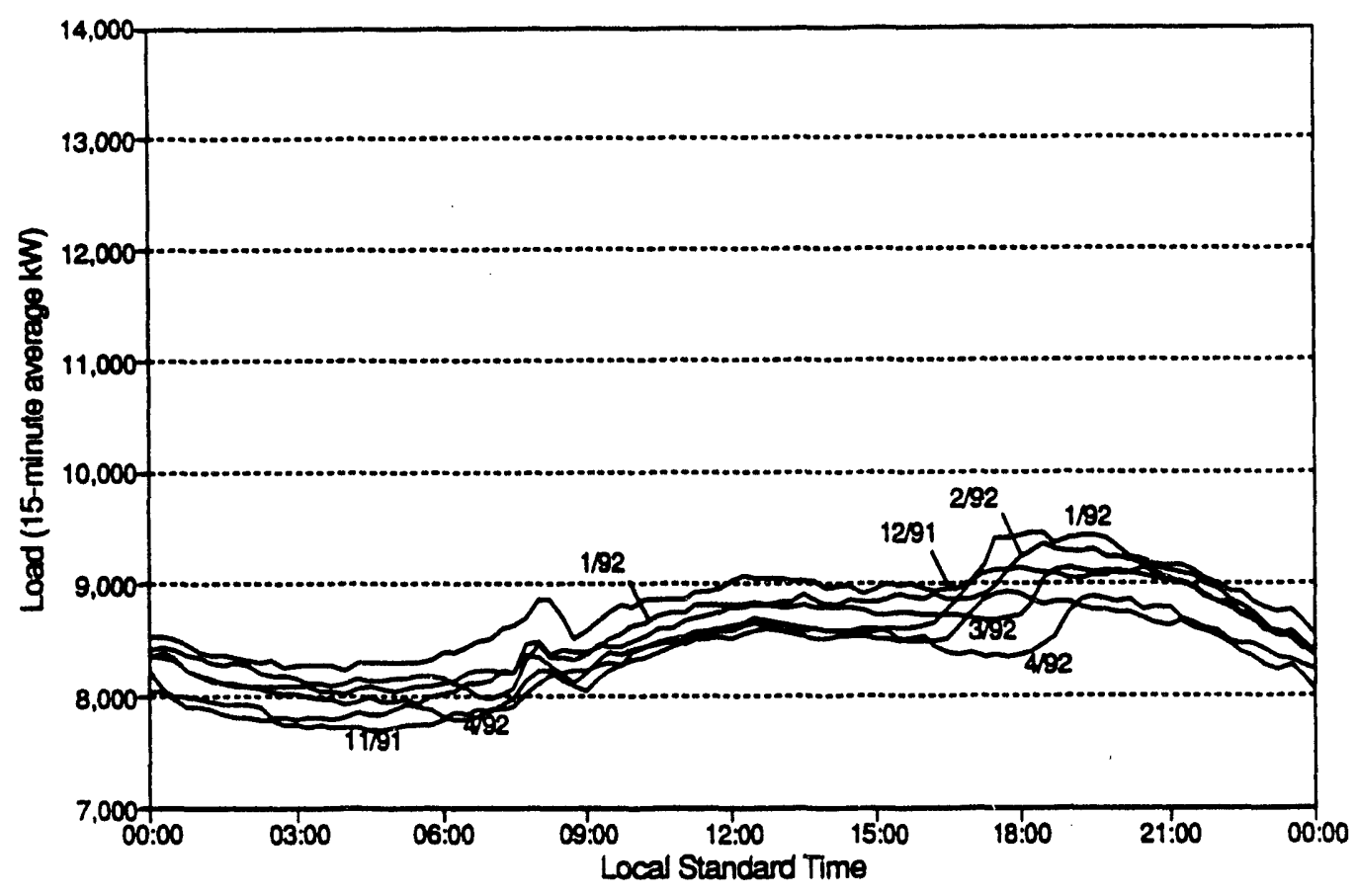

FIGURE 3.2. Monthly Average Weekend Electric Load Profiles 
The seasonal variation in daily profile indicates that there is a small electric demand associated with heating on weekends. There is an opposite variation of similar magnitude in weekday demand due to air conditioning. This will undoubtedly increase in magnitude during the summer months.

The magnitude of exterior, dormitory (this falls into the "BARRACKS" category defined in Table 1.2), and family housing lighting loads is apparent in the weekend profiles. The abrupt drop in the morning is due to the switching off of street and exterior lights that are controlled by time-clocks or photocells. The abrupt and large rise in the evening is due to the street and other exterior lights coming on and to manually controlled lights in residences coming on. The turn-off times of the latter are not apparent in the profiles because they are spread over the late evening hours. The clarity with which the seasonal change in sunrise and sunset times can be tracked is an interesting feature of the weekend profiles.

The monthly average weekday-minus-weekend load difference profiles are shown in Figure 3.3. The weekday profiles differ from the weekend profiles in having a much large additional load between 0700 and 1600 hours and a smaller additional load between 1600 and 2200 hours. The latter may be due to weekday evening shift work and partly to the typical behavior of residential loads wherein weekday evening loads are higher than weekend evening loads. Residential kitchen appliances and lights, commercial building loads (1ights, fans, air-conditioning, computers, and power tools), and water and sewer pumps are the main elements of this load difference. Street and exterior lights operated by time clocks and photocells have absolutely no systematic effect on the weekday-weekend difference profile.

Each difference profile can be analyzed in terms of four components: an evening load, a business-day load, and two commercial building components for air-conditioning and heating. The evening load difference is predominantly residential lighting and cooking. The business load difference consists of HVAC motors, lights, office equipment and power tools that represent a constant aggregate load between about 0700 and 1600 weekdays. Space heating in commercial buildings involves some intermittent fan and pump operation that results in an aggregate morning load that tapers off through the day in cold 


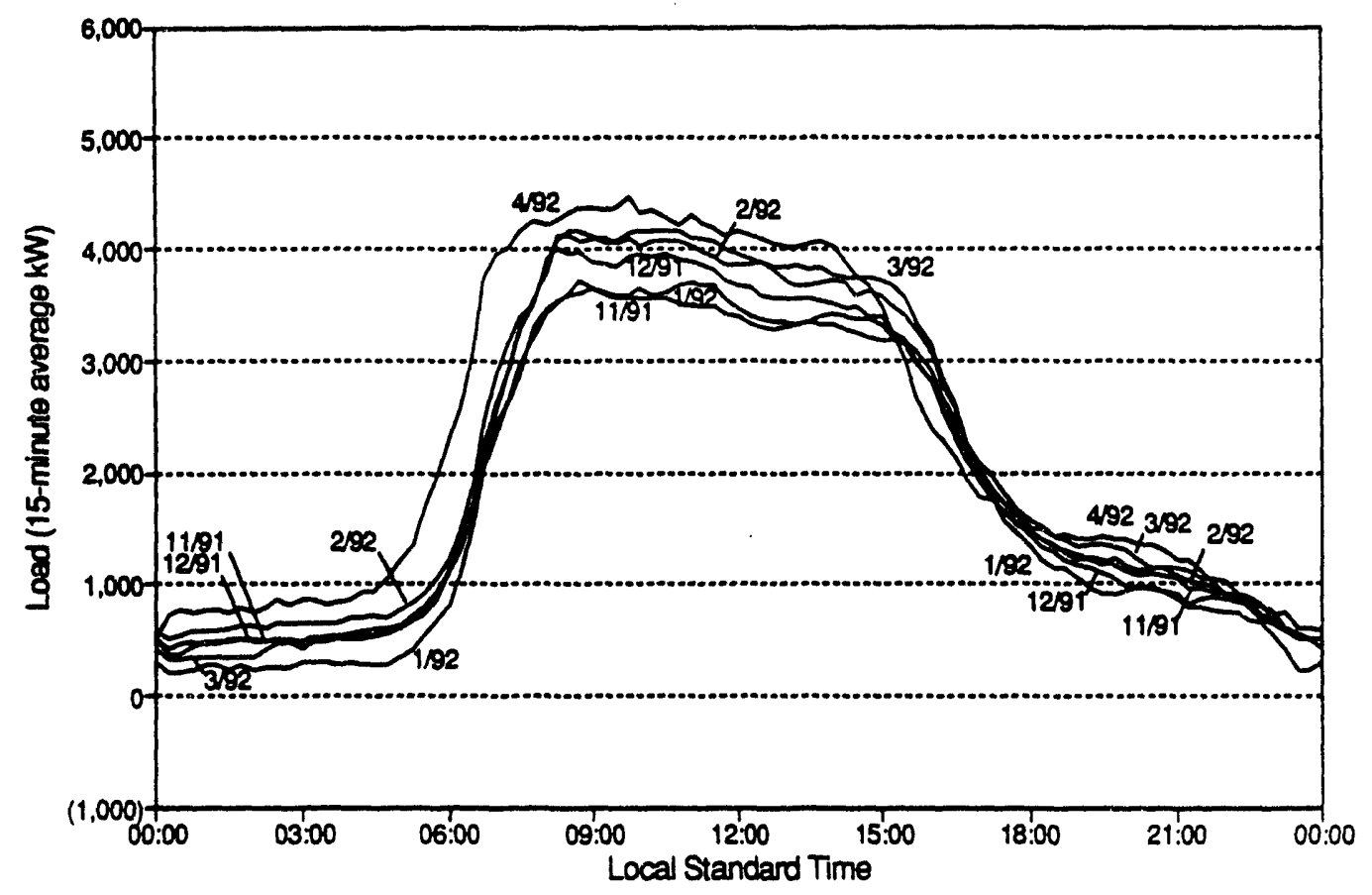

FIGUR[ 3.3. Monthly Average Weekday-Minus-Weekend Electric Load Profiles

months. Air conditioning also involves intermittent (and some modulating) motor operation that results in an aggregate load that increases during the day until about 4:30 p.m. when it falls abruptly. The heating and airconditioning components are seasonal in magnitude.

The extent to which the weekday-weekend differences in HVAC motor operation are due to weekend setback, as opposed to weekday-weekend differences in internal gains, cannot be readily determined. The one-hour shift that occurs for daylight savings time affects all four components of the load difference profile. The shift is clearly evident during the morning rise from $<1,000$ to $>3,000 \mathrm{~kW}$ and, to a lesser degree, at the afternoon crossings of the 2,000 to $3,000 \mathrm{~kW}$ band.

\subsubsection{Regional Time-of-Use}

Shown in Figure 3.4 are the workday load profiles of the supplier, Niagara Mohawk, suitably scaled for comparison and superimposed on the Griffiss AFB weekday profiles of Figure 3.1. The profile labeled "NM-summer" 


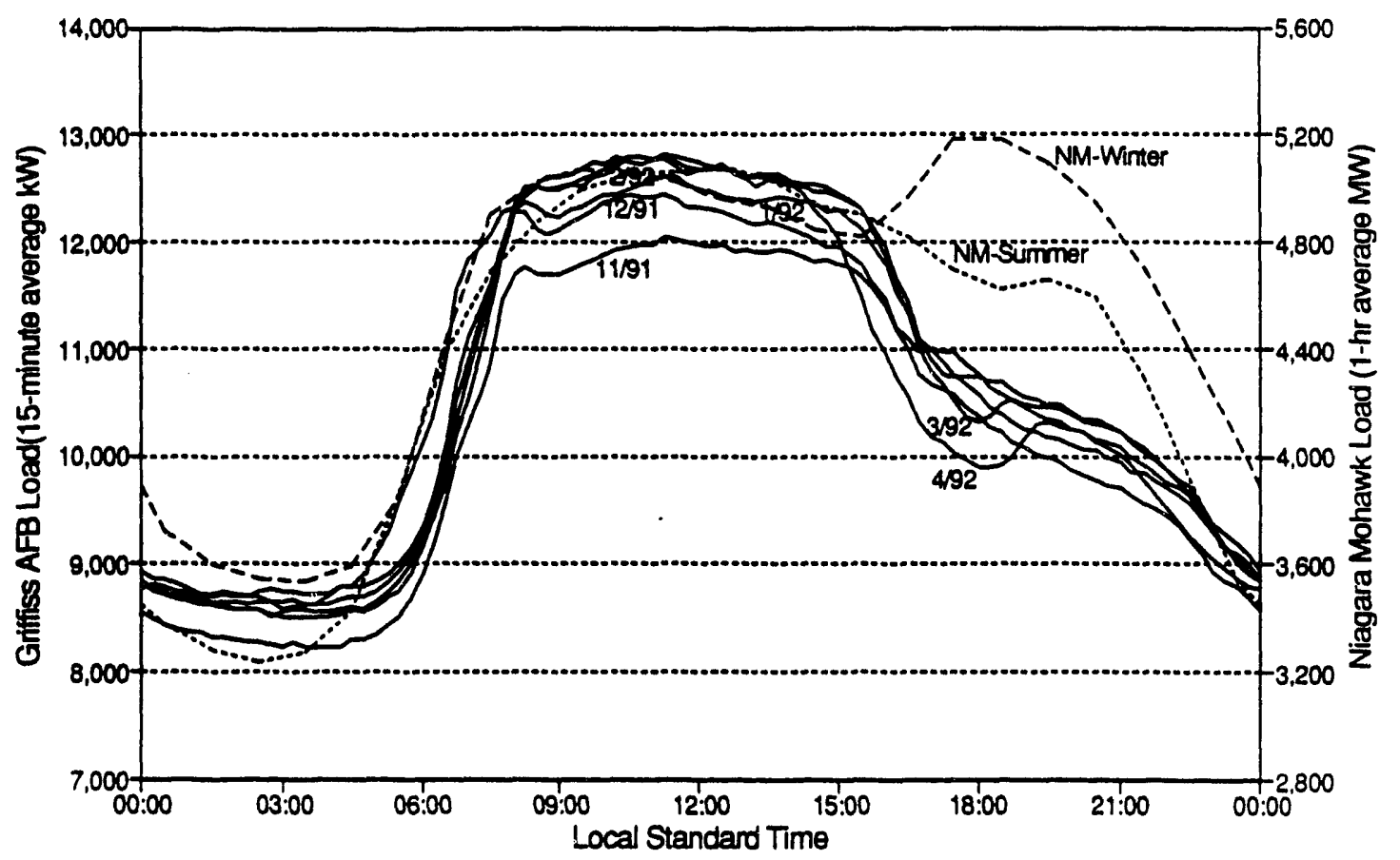

FIGURE 3.4. Comparison of Griffiss AFB Weekday Load Profiles and Niagara Mohawk Utility-Wide Workday Load Profiles

is the average of hourly loads for 106 working days in the period 1 May through 30 September 1991. The profile labeled "NM-winter" is the average of hourly loads for 83 working days in the period 1 0ctober 1991 though 31 January 1992.

Niagara Mohawk's local summer peaks occur at 13:00 and 20:00 local standard time. The evening peak coincides very nearly with the base's. The daytime peak, however, is about 2 hours later. Also note that the base's profile drops considerably between 15:00 and 19:00 LST, while the "NM-summer" profile drops very gradually. These differences are partly due to the lower use of air conditioning in the Rome area but mainly to the effects of off-post housing residents and civilian workers. The load effects of these people are always present on the Niagara Mohawk grid but are only present on the Griffiss AFB grid during working hours. Thus, the ratio of Griffiss AFB's winter weekday on-peak to weekday total consumption is $64 \%$, which is considerably higher than Niagara Mohawk's 55\%. 
The Niagara Mohawk winter peak occurs at 18:00 LST. A daytime peak that is about $2 \%$ lower occurs in the morning at 09:30. Griffiss AFB peaks just before 12:00 LST.

The seasonal variation in Griffiss AFB's load is small at all times of the daily and weekly cycles. The Niagara Mohawk load, on the other hand, while showing little seasonal variation during business hours, exhibits a relatively large seasonal variation of consumption during non-business hours. (The Niagara Mohawk load may have seasonal lows in the spring and fall but this cannot be determined with the summer and winter profile averaging periods used by Niagara Mohawk.)

Finally, note that Griffiss AFB uses about $0.25 \%$ of Niagara Mohawk's regional energy production.

\subsubsection{Consumption, Peak Demand and Reactive Demand Growth}

Figure 3.5 shows the variation in electric load from April 1988 through November 1992. Billing data are plotted by billing month. A billing month ends on the meter reading day of the month indicated on the horizontal axis of Figure 3.5. Meter reading days fall between the 15 th and 18 th of the month and are always on a weekday.

The seasonal variation is consistent from year to year and is characterized by summer and winter peaks of near equal magnitude. In fact, for monthly demand $(k W)$, the summer peak is slightly higher than the winter peak, whereas for consumption (kWh) the winter peak is slightly larger. The peak demand month is almost always August. The peak consumption usually occurs between mid-January and mid-February, but can occur in other winter months, depending on the weather. While there is a slight growth trend in 1988 and 1989, there is no significant change in the annual load from 1990 to 1992.

\subsubsection{Load Curves}

Monthly plots characterizing electric demand for the whole base are useful for determining the electric energy that would have to have been generated to limit the peak demand to a specific value. The relation between kWh (that must be generated) and $\mathrm{kW}$ shaved is plotted for each month in 


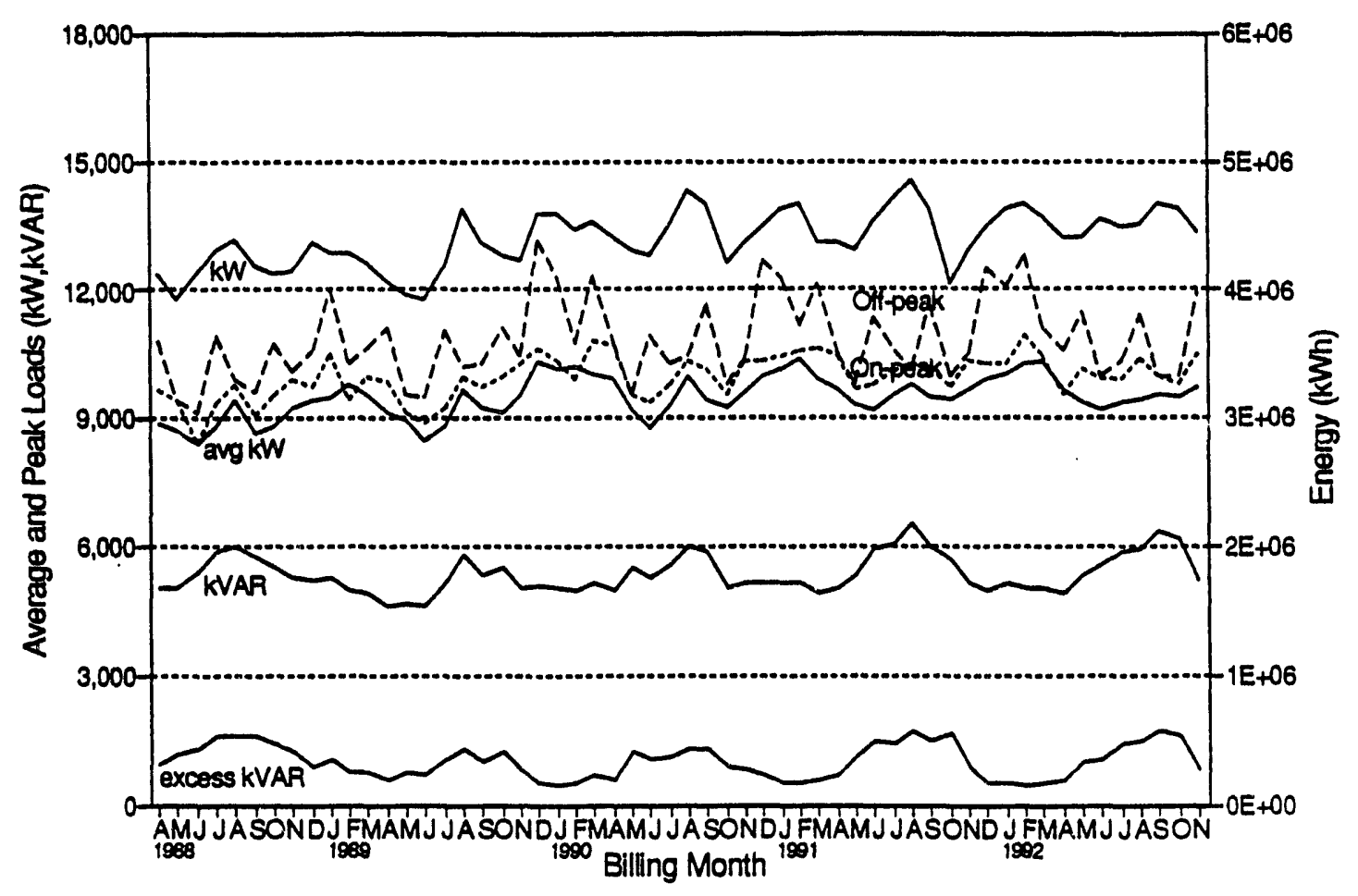

Avg, peak bads ..... Olt-peak energy - - On-peak energy

FIGURE 3.5. Niagara Mohawk Monthly Billing Data from 4/88 to $11 / 92$

Figure 3.6. The relation between $\mathrm{kWh}$ and $\mathrm{kW}$ shaved is shown for a year in Figure 3.7. Also shown in Figure 3.7 are the relation between full-loadequivalent run hours and $\mathrm{KW}$ shaved and the relation between total run hours and $\mathrm{kW}$ shaved. This information is needed to estimate savings for measures such as peak shaving by operation of existing diesel generators. 


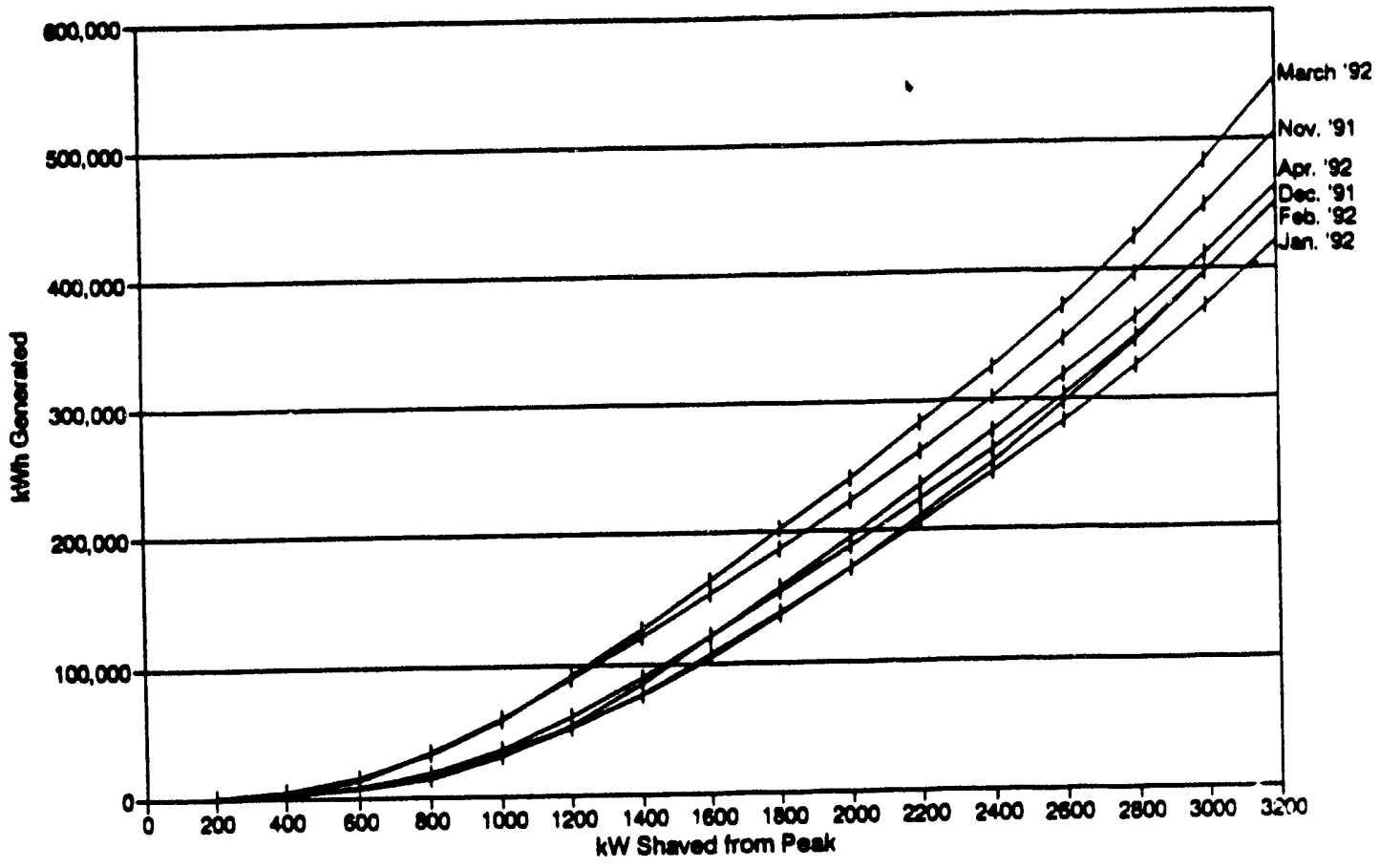

(The minimum energy (KWh) that must be generated each month is presented as a function of reduction in the monthly maximum 15-minute demand (kW). First costs are associated with the aggregate capacity of generators converted to peak-shaving duty and operating costs are aseociated with the energy (KWh) that must be produced at appropriate times to limit domand at the utility moter).

EIGURE 3.6. Monthly Peak Shaving Energy Cost Component 


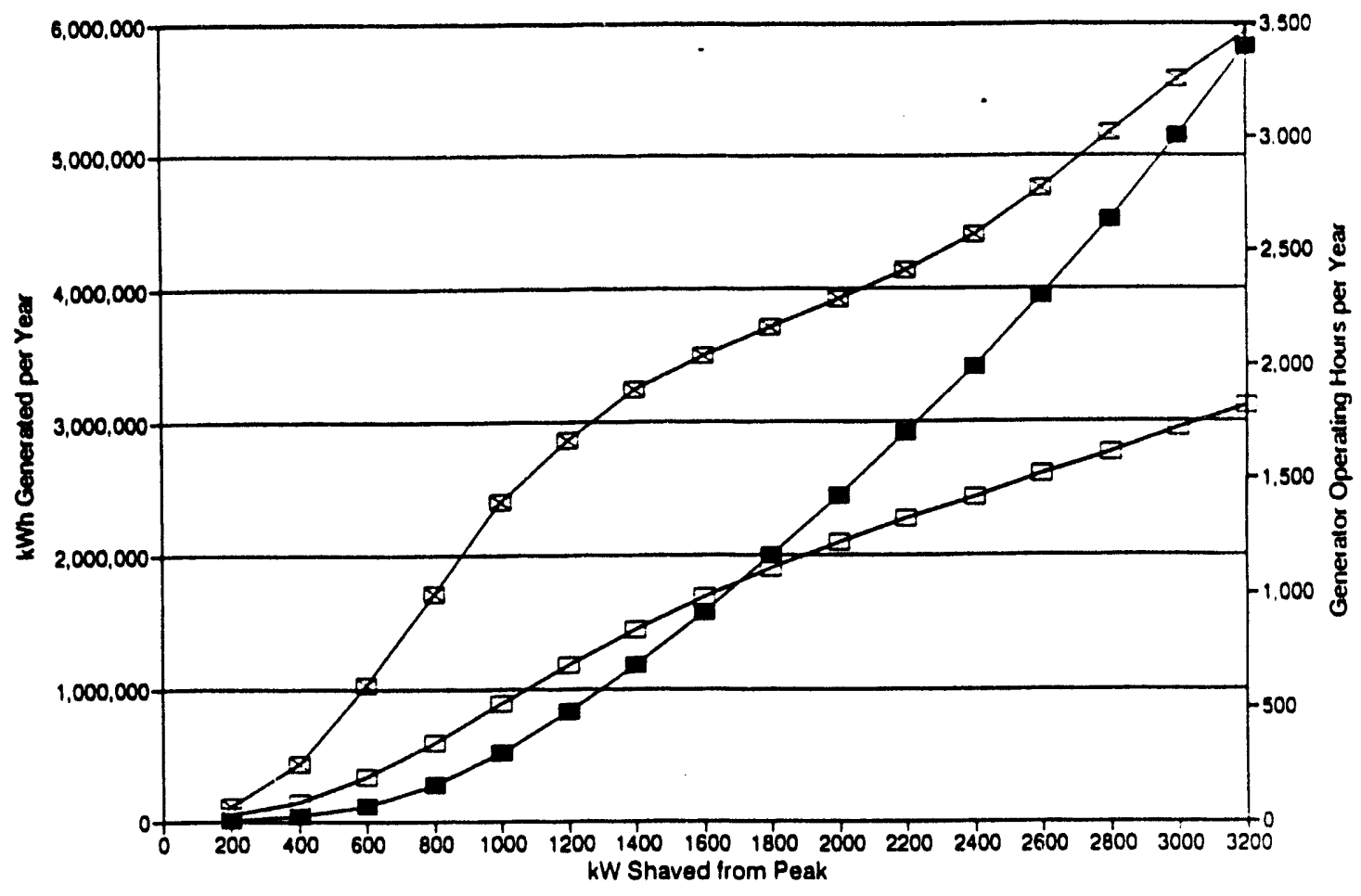

kWh Saved/Year E Equiv. Full Load $\mathrm{Hr} \rightleftharpoons$ Actual Operating $\mathrm{Hr}$

(Each component-kWh, Actual operating hours, and Full-Capacity Equivalent operating hours-is plotted as a function of monthly demand shaved. The curves are based on 1) a control strategy that accurately forecasts each monthly peak and thus provides a specified reduction in monthly demand with the minimum possible operating time and fuel consump. tion and 2) extrapolation of the November 1991 through April 1992 load history to a full year).

FIGURE 3.7. Annual Peak Shaving Energy and Maintenance Cost Components 


\subsection{MATURAL GAS CONSUMPTION}

\subsection{METERING AND DATA SUMMARY}

Natural gas is consumed at Griffiss AFB to heat dwelling units in the family housing areas, by the swimming pool, and in the new club. FY 1991 is the most recent year for which a complete set of data is available. The table below summarizes the total use of gas in FY 1991 for each housing area, along with the fuel cost and the calculated energy-use intensity (EUI).

\begin{tabular}{|l|ccrr||}
\hline \multicolumn{5}{|c|}{ Family Housing Gas Usage } \\
\hline Area Name & Cost & $\begin{array}{c}\text { Use } \\
\text { (Therms) }\end{array}$ & $\begin{array}{c}\text { EUI } \\
\text { (KBtu/ft }\end{array}$ \\
\hline Skyline & $\$ 241,475$ & 496,315 & 74.1 & FY 1991 \\
Woodhaven & $\$ 181,507$ & 349,543 & 103.3 & FY 1991 \\
\hline Totals & $\$ 422,982$ & 845,858 & & \\
\hline
\end{tabular}

The apparent EUI difference is probably due to the inclusion of unfinished basement area in the Real Property Database as was discussed in Section 1.2.2.

Total natural gas consumption in FY 1991 was $1,109,000$ therms $(110,990$ MBtu), or $9.0 \%$ of the overall Griffiss AFB energy consumption.

\subsection{ENERGY USE BREAKDOWN}

Analysis of natural gas consumption was not included in the scope of this assessment. 


\subsection{OIL CONSUMPIION}

\subsection{METERING AND DATA SUMMARY}

Total heating oil consumption, based on delivery records, was 218,000 gallons $(30,271 \mathrm{MBtu})$ at Griffiss AFB in FY 1990, or 2.5\% of the overall Griffiss AFB energy consumption.

\subsection{ENERGY USE BREAKDOWN}

Fuel oil is used for heating in most outlying butldings not arved by the steam loop. These include the farmhouses, weapon storage areas, and Building 793. Fuel ofl is also used in back-up bollers provided in many buildings to avoid hot water interruptions during steam $p l$ ant maintenance. The Oneida County Public Works Department steam plant is typically taken out of service for 1 week each summer. Further analysis of heating oil consumption was not within the scope of this assessment. 


\subsection{PROPANE CONSUMPTION}

\subsection{METERING AND DATA SUMMARY}

Total propane consumption at Griffiss AFB was 19,800 gallons

$(1,820 \mathrm{MBtu})$ in FY 1990, or $0.1 \%$ of the overall Griffiss AFB energy consumption.

\subsection{ENERGY USE BREAKDOWN}

Analysis of propane consumption was not within the scope of this assessment. 


\subsection{COAL CONSUMPTION}

7.1 METERING AND DATA SUMMARY

Total coal consumption was 26,450 tons $(648,095$ MBtu) in FY 1990, or $13.7 \%$ of the overall Griffiss AFB energy consumption.

\subsection{ENERGY USE BREAKDOWN}

Analysis of coal consumption was not within the scope of this assessment. 


\subsection{PURCHASED STEAM CONSUMFTION}

\subsection{METERING AND DATA SUMMARY}

The thermal energy consumption by Griffiss AFB is metered at the onsite plant and by the offsite supplier. There are daily logs of steam flow and condensate return at the onsite plant. Oneida County Public Works Department al so supplies a morithly summary of consumption and billing information. Total energy delivered to the steam distribution system from the county plant in FY 1990 was 169,000 MBtu, or $13.7 \%$ of the overall liriffiss AFB energy consumption.

\subsection{ENERGY USE BREAKDOWN}

Analysis of steam consumption was not within the scope of this assessment. 


\subsection{ENERGY-USE INTENSITIES}

This section presents estimates of site-specific energy-use intensities (EUI) by building type and end use and describes their development. Section 9.1 is a survey of regional end-use studies that report energy use intensities by building type. Section 9.2 summarizes the EUI data that is relevant to the buildings at Griffiss AFB. This data serves as a starting point for the site-specific analysis of section 9.3. Section 9.4 presents the results of the site-specific disaggregation of whole building EUI estimates into estimates of energy use intensity by end use.

\subsection{INITIAL ENERGY-USE INTENSITY DATA}

EUIs are defined as energy use per unit area, per unit time. EUIs are commonily expressed as thousands of British thermal units per square foot per year $\left(k B t u / f^{2}-y r\right)$, or kilowatt-hours per square foot per year $\left(k W h / \mathrm{ft}^{2}-\mathrm{yr}\right)$.

Tables 9.1 through 9.3 summarize the results of several regional end-use EUI surveys. EUIs are estimated by building type, fuel type, and fuel end use. Energy use is expressed in $\mathrm{kWh} / \mathrm{ft}^{2}-\mathrm{yr}$ for electric EUIs and $\mathrm{kBtu} / \mathrm{ft}^{2}-\mathrm{yr}$ for fossil fuel EUIs. End-use data are for the following end-use categories: space heating, cooling, ventilation, domestic hot water (DHW), cooking, lighting (includes interior and exterior), refrigeration, and other. The "other" category covered miscellaneous end uses made up of a variety of electric appliances and motors as well as water/steam heating for laundry or food preparation. Significant, differences in how the surveys defined the "other" category are noted in the tables.

Tables 9.1 and 9.3 present the survey and analysis resuits (Xenergy 1987a, 1987b, 1988; NYSEO 1986, 1987; DOE-EIA 1986, 1987) reported by Xenergy, NYS-ERDA (New York State Energy Research and Development Authority) and the DOE-EIA RECS (Residential Energy Consumption Survey) and CBECS (Commercial Building Energy Consumption Survey). Results of the ACEEE (American Council for an Energy-Efficient Economy) analysis (ACEEE 1988) of residential end-use EUIs also appear in these tables. The electric end-use results appear in Table 9.1 and the fossil fuel end-use results appear in Table 9.3. 
IABLE 9.1. Regional EUI Survey Results ( $k W h / \mathrm{ft}^{2}-\mathrm{yr}$ )

Heat Cool Vent DHW Cook Light Ref Other Iotal

Single-Family Residence

Xenergy
NYSEO
ACEEE (c)
RECS NE (e)
RECS MA (f)

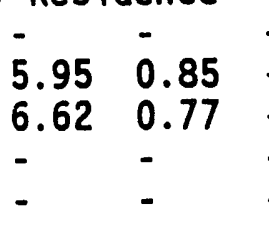

Multi-Family Residence

Xenergy
NYSEO

ACEEE

RECS NE

RECS MA

Hotel

Xenergy ${ }^{(h)}$

NYSEO
CBECS $^{(k)}$

Office

Xenergy

NYSEO

CBECS

Grocery

Xenergy $(1)$

NYSEO

CBECS $^{(n)}$

Restaurant

Xenergy

CBECS $^{(q)}$

Hospita]

$\begin{array}{llll}\text { Xenergy }_{\text {N }}^{(r)} & 26.54 & 1.49 & 2.02 \\ \text { NYSEO }^{(3)} & 21.59 & 1.46 & 1.84\end{array}$

CBECS $^{(t)}$

Retail

Xenergy(u)

NYSEO

CBECS $^{(w)}$

$$
7.32 \overline{1} .13
$$

$12.59 \quad 1.38$

$11.99 \quad 1.37$

0.85

0.79

$12.89 \quad 1.70$

1.08

$19.10 \quad 1.90$

0.82

$\begin{array}{lll}11.75 & 2.14 & 1.08\end{array}$

$\begin{array}{lll}11.87 & 2.17 & 0.79\end{array}$
3.89

10.84

4.39

$\begin{array}{ll}1.69 & 2.91^{(1)} \\ 0.81 & 1.64^{(d)}\end{array}$

38.54

3.75

$\overline{1.38} \quad \overline{1.32^{(b)}} \quad \overline{5} .33$

$-$

$-$

32.21

11.19

$\begin{array}{llll}16.23 & 1.87 & 1.05 & 1.29\end{array}$

3.13
2.14

5.62

$\begin{array}{lll}3.37 & 4.51^{(i)} & 37.07 \\ 0.27 & 3.50^{(d)} & 31.56 \\ - & - & 19.95\end{array}$

$\begin{array}{llll}21.86 & 2.60 & 2.02 & 1.08\end{array}$

$\begin{array}{lll}4.48 & 15.97 & 23.03\end{array}$

$4.34 \quad 14.96$

24.92

$3.19^{\text {(d) }} 74.23$

$\begin{array}{llll}20.79 & 2.68 & 1.98 & 1.08\end{array}$

3.95

$\begin{array}{ll}34.9 & 7.06 \\ 47.57 & 5.94\end{array}$

$\begin{array}{ll}7.06 & 1.87^{(d)} \\ 8.71 & 2.86^{(d)}\end{array}$

70.51

4.6547 .57

$-$

18.63

5.86

$9.08 \quad 5.01$

$\begin{array}{lll}0.44 & 9.73^{(1)} & 60.17 \\ 0.65 & 4.78^{(d)} & 48.23 \\ - & - & 18.17\end{array}$

0.38

2.11

5.33

$\begin{array}{lll}3.31 & 2.08^{(i)} & 28.18 \\ 1.82 & 2.86^{(d)} & 26.03\end{array}$

0.36

1.82

4.34

9.93 
TABLE 9.1. (contd)

Heat Cool Vent DHW Cook Light Ref other Total

\begin{tabular}{|c|c|c|c|c|c|c|c|c|c|}
\hline $\begin{array}{l}\text { Warehouse } \\
\text { Xenergyy } \\
\text { NYSEO } \\
\text { CBECS(y) }\end{array}$ & $\begin{array}{r}15.96 \\
2.50 \\
-\end{array}$ & $\begin{array}{l}1.35 \\
1.81 \\
-\end{array}$ & $\begin{array}{l}0.56 \\
0.51 \\
-\end{array}$ & $\begin{array}{l}0.18 \\
0.31 \\
-\end{array}$ & $\begin{array}{l}4.72 \\
- \\
-\end{array}$ & $\begin{array}{l}1.73 \\
2.04 \\
-\end{array}$ & $\begin{array}{l}0.59 \\
3.76 \\
-\end{array}$ & $\begin{array}{l}0.79^{(d)} \\
1.99^{(d)} \\
-\end{array}$ & $\begin{array}{r}25.88 \\
12.92 \\
6.65\end{array}$ \\
\hline
\end{tabular}

(a) NYSEO data available only as UEC (unit energy consumption). EUI calculated assumes $1500 \mathrm{ft}^{2}$ per single family residence.

(b) Defined as miscellaneous EUI, includes lighting.

(c) ACEEE data available only as UEC. EUI calculated assumes $1750 \mathrm{ft}^{2}$ per single family residence for all but space heating end use where the DOE-2 estimate of $2200 \mathrm{ft}^{2}$ per single family residence was used.

(d) Defined as miscellaneous EUI.

(e) RECS NE data is for the New England region. EUI calculated assumes $1500 \mathrm{ft}^{2}$ per single family residence.

(f) RECS MA data is for the Mid Atlantic region. EUI calculated assumes $1500 \mathrm{ft}^{2}$ per single family residence.

(g) NYSEO data available only as UEC (unit energy consumption). EUI calculated assumes $1000 \mathrm{ft}^{2}$ per single family residence.

(h) Xenergy data for hotel/motel category, includes lodging only (26.9\%) and multi-function (73.1\%).

(i) Defined as miscellaneous and process EUI.

(j) NYSEO data for hotel category.

(k) CBECS data for lodging category.

(1) Xenergy data for food store category, includes grocery/food store (91\%) and convenience market $(9 \%)$.

(m) NYSEO data for grocery category.

(n) CBECS data for food sales category.

(o) Xenergy data for restaurant category, includes fast food (10.2\%), bar/tavern (38.4\%) and ful1 service (51.4\%).

(p) NYSEO data for restaurant category.

(q) CBECS data for food services category.

(r) Xenergy data for hospital category.

(s) NYSEO data for medical center category.

(t) CBECS data for heal th care category.

(u) Xenergy data for retail category, includes miscellaneous (51.1\%), major department stores (26.6\%) and auto dealer (20.3\%).

(v) NYSEO data for retail store category.

(w) CBECS data for mercantile/service category.

(x) Xenergy data for non-refrigerated warehouse category.

(y) NYSEO and CBECS data are defined for a category that includes both refrigerated and non-refrigerated warehouses. 
IABLE 9.2. Saturation Weighted EUI Survey Results (kWh/ft2-yr)

\begin{tabular}{|c|c|c|c|c|}
\hline & $\underline{H V A C}^{(\mathrm{a})}$ & Lighting & $\underline{M i s c}^{(a)}$ & Iotal \\
\hline $\begin{array}{l}\text { Hotel } \\
\text { ACEEE } \\
\text { CEDMS } \\
\text { Con Ed } \\
\text { NMPC } \\
\text { Mass. Elec. }\end{array}$ & $\begin{array}{l}7.7 \\
8.5 \\
2.8 \\
5.7 \\
5.2\end{array}$ & $\begin{array}{l}3.3 \\
4.7 \\
3.4 \\
4.0 \\
3.9\end{array}$ & $\begin{array}{l}1.9 \\
2.3 \\
4.9 \\
4.4 \\
4.6\end{array}$ & $\begin{array}{l}12.9 \\
16.8 \\
11.1 \\
14.2 \\
13.7\end{array}$ \\
\hline $\begin{array}{l}\text { Office } \\
\text { ACEEE } \\
\text { CEDMS } \\
\text { Con Ed } \\
\text { NMPC } \\
\text { Mass. Elec. } \\
\text { Grocery }\end{array}$ & $\begin{array}{r}16.5 \\
6.8 \\
1.9 \\
5.1 \\
4.2\end{array}$ & $\begin{array}{l}6.6 \\
8.9 \\
6.2 \\
5.2 \\
3.3\end{array}$ & $\begin{array}{l}1.0 \\
0.3 \\
7.6 \\
4.3 \\
3.2\end{array}$ & $\begin{array}{l}24.1 \\
16.2 \\
16.0 \\
14.5 \\
10.7\end{array}$ \\
\hline $\begin{array}{l}\text { Grocery } \\
\text { ACEEE } \\
\text { CEDMS } \\
\text { Con Ed } \\
\text { NMPC } \\
\text { Mass. Eleq. } \\
\text { Ft. Lewis }\end{array}$ & $\begin{array}{l}6.1 \\
5.7 \\
4.6 \\
5.8 \\
5.6\end{array}$ & $\begin{array}{r}12.4 \\
12.7 \\
12.4 \\
15.7 \\
8.0 \\
-\end{array}$ & $\begin{array}{l}34.5 \\
32.5 \\
39.8 \\
27.1 \\
13.3\end{array}$ & $\begin{array}{l}52.9 \\
51.1 \\
56.7 \\
48.6 \\
26.9 \\
49.0\end{array}$ \\
\hline $\begin{array}{l}\text { Restaurant } \\
\text { ACEEE }\end{array}$ & - & - & - & - \\
\hline $\begin{array}{l}\text { CEDMS } \\
\text { Con Ed }\end{array}$ & - & 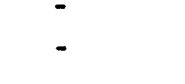 & 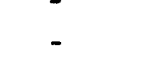 & - \\
\hline 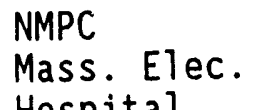 & - & - & - & - \\
\hline $\begin{array}{l}\text { Hospital } \\
\text { ACEEE } \\
\text { CEDMS } \\
\text { Con Ed } \\
\text { NMPC } \\
\text { Mass. Elec. } \\
\text { Retail }\end{array}$ & $\begin{array}{l}8.3 \\
5.9 \\
1.9 \\
4.7 \\
6.4\end{array}$ & $\begin{array}{l}6.0 \\
7.3 \\
4.4 \\
5.0 \\
6.8\end{array}$ & $\begin{array}{l}3.9 \\
2.3 \\
8.1 \\
8.9 \\
10.8\end{array}$ & $\begin{array}{l}18.2 \\
16.2 \\
14.4 \\
18.6 \\
24.0\end{array}$ \\
\hline $\begin{array}{l}\text { Retail } \\
\text { ACEEE } \\
\text { CEDMS } \\
\text { Con Ed } \\
\text { NMPC } \\
\text { Mass. Elec. }\end{array}$ & $\begin{array}{l}12.8 \\
4.8 \\
2.0 \\
1.9 \\
1.3\end{array}$ & $\begin{array}{l}6.2 \\
6.1 \\
6.4 \\
5.1 \\
4.4\end{array}$ & $\begin{array}{l}0.5 \\
0.2 \\
5.1 \\
2.0 \\
1.5\end{array}$ & $\begin{array}{r}19.4 \\
11.1 \\
13.5 \\
9.0 \\
7.2\end{array}$ \\
\hline $\begin{array}{l}\text { Warehouse } \\
\text { ACEEE }\end{array}$ & - & - & $=$ & - \\
\hline $\begin{array}{l}\text { CEDMS } \\
\text { Con Ed } \\
\text { NMPC }\end{array}$ & - & - & - & - \\
\hline Mass. Elec. & - & - & - & - \\
\hline
\end{tabular}

(a) Definitions of HVAC \& MisC end-use differ among studies for all building

(b) Based on metered data for Fort Lewis Commissary, built in 1987 (Test Report Lewis 005-90/07/27, Commissary Electric Profile). 
IABLE 9.3. Regional Fossil Fuel EUI Survey Results (kBtu/ft²-yr)

\begin{tabular}{|c|c|c|c|c|c|}
\hline Sinale Family Residence & Heating & DHW & Cooking & Other & Iotal \\
\hline $\begin{array}{l}\text { NG-NYSEO } \\
\text { NG-RECS N.E. (b) }\end{array}$ & 65.27 & 19.73 & 6.33 & - & 91.33 \\
\hline $\begin{array}{l}\text { NG-RECS N.E. } \\
\text { NG-RECS M.A. }\end{array}$ & - & - & 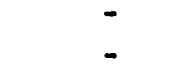 & - & $\begin{array}{l}82.3 \\
78.3\end{array}$ \\
\hline $\begin{array}{l}\text { FO-NYSEO } \\
\text { FO-RECS N.E. }\end{array}$ & 47.67 & 14.56 & - & - & 62.23 \\
\hline $\begin{array}{l}\text { FO-RECS N.E. } \\
\text { FO-RECS M.A. }\end{array}$ & - & - & - & - & $\begin{array}{l}71.4 \\
74.47\end{array}$ \\
\hline LP-NYSEO & - & - & 8.26 & - & 8.26 \\
\hline LP-RECS N.E. & - & - & - & - & 6.6 \\
\hline $\begin{array}{l}\text { LP-RECS M.A. } \\
\text { Multi-Family Residence }\end{array}$ & - & - & - & - & - \\
\hline $\begin{array}{l}\text { NG-XenergY } \\
\text { NG-NYSEO }\end{array}$ & 81.2 & 24.1 & 8.6 & - & 113.9 \\
\hline FO-Xenergy & - & - & & - & \\
\hline FO-NYSEO & 59.53 & 18.58 & - & - & 78.11 \\
\hline $\begin{array}{l}\text { LP-Xenergy } \\
\text { P-NYSEO }\end{array}$ & - & - & 11.6 & 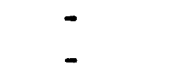 & 11.6 \\
\hline Hotel (e) & & & & & \\
\hline $\begin{array}{l}\text { NG-Xenergy (e) } \\
\text { NG-NYSEO } \\
\text { NG-CBECS } \\
\text { (i) }\end{array}$ & $\begin{array}{l}71.7 \\
67.38\end{array}$ & $\begin{array}{l}15.1 \\
26.72\end{array}$ & $\begin{array}{l}23.7 \\
5.96\end{array}$ & $\begin{array}{l}8.3^{(1)} \\
0.53^{(h)}\end{array}$ & $\begin{array}{c}118.8 \\
100.59 \\
46.2\end{array}$ \\
\hline $\begin{array}{l}\text { FO-Xenergy } \\
\text { FO-NYSEO }\end{array}$ & $\begin{array}{l}169.4 \\
67.38\end{array}$ & $\begin{array}{l}24 . \\
13.54\end{array}$ & 5.9 & - & $\begin{array}{c}199.3 \\
80.92\end{array}$ \\
\hline $\begin{array}{l}\text { FO-CBECS } \\
\text { LP-Xenergy }\end{array}$ & 45.9 & $12^{-} .6$ & 52.3 & $\begin{array}{l}- \\
-\end{array}$ & 110.8 \\
\hline LP-NYSEO & - & - & - & - & \\
\hline $\begin{array}{l}\text { LP-CBECS } \\
\text { Office }\end{array}$ & - & - & - & - & - \\
\hline NG-Xenergy & 73.5 & 31.6 & 14.8 & $13.5^{(\mathrm{J})}$ & 133.4 \\
\hline $\begin{array}{l}\text { NG-NYSEO } \\
\text { NG-CBECS }\end{array}$ & 77.44 & 6.65 & 9.04 & $0.15^{(h)}$ & $\begin{array}{l}93.28 \\
26.9\end{array}$ \\
\hline $\begin{array}{l}\text { FO-Xenergy } \\
\text { FO-NYSEO }\end{array}$ & 83.0 & 16.5 & - & $0.9^{(f)}$ & $\begin{array}{l}100.4 \\
80.63\end{array}$ \\
\hline $\begin{array}{l}\text { FO-NYSEO } \\
\text { FO-CBECS }\end{array}$ & $\div$ & $\begin{array}{c}43.19 \\
-\end{array}$ & - & - & 36.4 \\
\hline LP-Xenergy & 212.0 & 7.7 & 27.9 & - & 247.6 \\
\hline LP-NYSEO & - & - & - & - & - \\
\hline $\begin{array}{l}\text { LP-CBECS } \\
\text { Grocery Store }\end{array}$ & & - & & - & - \\
\hline $\begin{array}{l}\text { Gocery Stgre } \\
\text { NG-Xenergg(k) } \\
\text { NG-NYSEO }\end{array}$ & $\begin{array}{l}107.2 \\
116.84\end{array}$ & $\begin{array}{c}3.5 \\
14.73\end{array}$ & $\begin{array}{l}11.1 \\
58.46\end{array}$ & $3.14^{(h)}$ & $\begin{array}{l}121.8 \\
193.17\end{array}$ \\
\hline$N G-C B E C S^{(m)}$ & - & & & & - \\
\hline $\begin{array}{l}\text { F0-Xenergy } \\
\text { FO-NYCFO }\end{array}$ & $\begin{array}{l}46.9 \\
116.84\end{array}$ & 24 & - & - & $\begin{array}{r}46.9 \\
119.24\end{array}$ \\
\hline FO-CBECS & $\begin{array}{c}116.84 \\
-\end{array}$ & 2.4 & - & & $119 .<4$ \\
\hline energy & 89.2 & - & - & - & 89.2 \\
\hline & - & - & - & & - \\
\hline ECS & & - & & & - \\
\hline
\end{tabular}


TABLE 9.3. (contd)

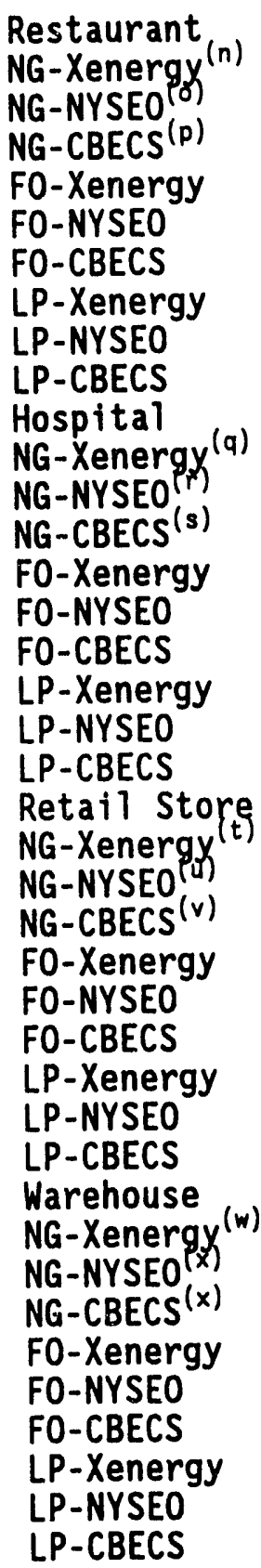

Heating DHW Cooking other Total

$\begin{array}{ccccc}76.7 & 20.4 & 160.4 & 5.1^{(f)} & 262.6 \\ 107.34 & 41.01 & 125.31 & 3.6^{(h)} & 277.26 \\ - & - & - & - & 144.3 \\ 113.2 & 37.0 & - & - & 150.2 \\ 107.34 & 83.81 & - & - & 191.15 \\ - & - & - & - & - \\ 192.0 & 18.9 & 90.5 & 7.3^{(f)} & 308.7 \\ - & - & - & - & - \\ - & - & - & - & -\end{array}$

$\begin{array}{ccccc}314.3 & 20.6 & 44.2 & 198.1^{(\mathrm{j})} & 577.2 \\ 121.34 & 15.15 & 12.81 & 1.13^{(\mathrm{h})} & 150.43 \\ - & - & - & - & 97.1 \\ 131.1 & 32.7 & 44.9 & 98.6^{(j)} & 307.3 \\ 121.34 & 28.81 & - & - & 150.15 \\ - & - & - & - & - \\ - & - & 38.5 & - & 38.5 \\ - & - & - & - & - \\ - & - & - & - & -\end{array}$

$\begin{array}{ccccc}63.3 & 7.1 & 10.7 & - & 81.1 \\ 66.71 & 5.86 & 11.94 & 2.66^{(h)} & 87.17 \\ - & - & - & - & 29.1 \\ 71.7 & 2.6 & - & - & 74.3 \\ 66.71 & 2.05 & - & - & 68.76 \\ - & - & - & - & 54.2 \\ 62.9 & 1.7 & 22.1 & 3.6^{(f)} & 90.3 \\ - & - & - & - & - \\ - & - & - & - & -\end{array}$

$\begin{array}{ccccc}37.6 & 1.2 & 16.1 & 4.0^{(f)} & 58.9 \\ 14.05 & 1.14 & 6.56 & 0.65^{(h)} & 22.4 \\ - & - & - & - & 24.2 \\ 83.9 & 0.9 & - & 9.8^{(f)} & 94.6 \\ 14.05 & 0.17 & - & - & 14.22 \\ - & - & - & - & 34.1 \\ 104.4 & - & - & - & 104.4 \\ - & - & - & - & - \\ - & - & - & - & -\end{array}$

(a) NYSEO data available only as UEC (unit energy consumption). EUI calculated assumes $1500 \mathrm{ft}^{2}$ per single family residence.

(b) RECS N.E. data for New England region. RECS N.E. data available only as UEC (unit energy consumption). EUI calculated assumes $1500 \mathrm{ft}^{2} \mathrm{per}$ single-family residence.

(c) RECS M.A. data for Mid Atlantic region. RECS M.A. data available only as UEC (unit energy consumption). EUI calculated assumes $1500 \mathrm{ft}^{2}$ per single-family residence.

(d) Data available only as UEC (unit energy consumption). EUI calculated assumes $1000 \mathrm{ft}^{2}$ per multi-family residence. 


\section{TABLE 9.3. (contd)}

(e) Xenergy data for hotel/motel category, includes lodging-only (26.9\%) and multi-function (73.1\%).

(f) defined as process EUI.

(g) NYSEO data for hotel category.

(h) defined as miscellaneous EUI.

(i) CBECS data for lodging category.

(j) defined as process EUI, includes cooling.

(k) Xenergy data for food store category, includes grocery/food store (91\%) and convenience market ( $9 \%)$.

(1) NYSEO data for grocery category.

(m) CBECS data for food sales category.

(n) Xenergy data for restaurant category, includes fast food $(10.2 \%)$, bar/tavern (38.4\%) and full service (51.4\%).

(0) NYSEO data for restaurant category.

(p) CBECS data for food service category.

(q) Xenergy data for hospital category.

(r) CBECS data for health care category.

(s) Xenergy data for retail category, includes miscellaneous $(51.1 \%)$, major department stores $(24.6 \%)$ and auto dealer (20.3\%).

(t) NYSEO data for retail store category.

(u) NYSEO data for medical center category.

(v) CBECS data for mercantile/service category.

(w) Xenergy data for non-refrigerated warehouse.

(x) NYSEO and CBECS data for refrigerated and non-refrigerated warehouse.

Table 9.2 presents the electric end-use analysis results reported by ACEEE, CEDMS, Consolidated Edison (NY), Niagara Mohawk, and Massachusetts Electric.

The results reported in Table 9.2 have been separated from the results reported in Tables 9.1 and 9.3 because different reporting conventions are used. The numbers in Table 9.2 are saturation-weighted electric EUIs. The end-use categories are more general than the categories used by the studies reported in Table 9.1. The usable data from Table 9.2 was therefore 1 imited to lighting EUIs, and the discussion that follows pertains to Tables 9.1 and 9.3 only.

While some of the EUI values correlate very well among the surveys for a given building type, fuel type, and end use, other values do not. The largest discrepancy is between the CBECS survey and the other two surveys. In most 
cases, the CBECS values are lower than the values from the other two surveys, in some cases by a factor of $1 / 2$ to $1 / 3$. There are a number of explanations for these discrepancies.

One possible explanation for discrepancies is that the CBECS data is not specific to one particular utility service territory; rather the data is for nine states that make up the northeast region of the United States. In this region, a large fraction of the population resides in coastal cities. Coastal cities have relatively mild winter climates, as compared with inland cities, which are generally associated with lower heating EUIs.

A second factor contributing to lower CBECS values is the CBECS EUI reporting convention. CBECS reports EUIs by building type and fuel but does not report the proportions of the different fuels used for each end use. The resulting EUIs represent an average of some, but not a11, end uses for a given building and fuel type. The CBECS EUIs are, therefore, expected to be lower than the EUIs which represent all end uses, as is the case for the EUIs reported by Xenergy and NYSEO.

Discrepancies between data from the two sources specific to the Niagara Mohawk service area are significant for a few building types. Again there are a number of possible reasons for these discrepancies.

One possible reason for discrepancies is variation in building geometry (size and shape) sampled by each survey. Small buildings of a given building type are generally less energy intensive (lower EUI) than large buildings. The number of stories also affects the energy use intensity of a building. A building having 100,000 ftz and five stories would be expected to have a lower heating EUI than a $100,000 \mathrm{ftz}^{2}$ one story building.

A second possible source of discrepancy is variation in function within a building type category. The hospital category is a good example. Xenergy reports an electric EUI of $60.17 \mathrm{kWh} / \mathrm{ft}^{2}-y r$ for the hospital category. NYSEO reports an electric EUI of $48.23 \mathrm{kWh} / \mathrm{ft}^{2}-\mathrm{yr}$ but includes medical centers as well as hospitals in the category's scope. Medical centers tend to be smaller, less energy intensive buildings than hospitals and would therefore be expected to have a lower average EUI. 
Other factors that can contribute to the discrepancies are building age, construction type, occupant density and schedules, and implemented energy conservation measures. All these factors can lead to significant variation in average EUI for a given building type category.

\subsection{SUMMARY OF INITIAL ENERGY END-USE VALUES}

A primary product of the energy consumption analysis for Griffiss AFB is a set of site-specific EUI values for the building types and end uses at the base. The EUIs have been determined from aggregate, rather than directly measured, energy deliveries. Some error is inevitable in the disaggregation process. However, these EUI estimates are consistent with all available energy use records and are consistent with regional estimates of energy use by building type. The estimates are therefore considered to be sufficiently accurate for identification and ranking of energy projects. More detailed connected load inventories of targeted end-use equipment should be obtained in many cases prior to implementation of the conservation and efficiency measures recommended in Volume 1 of this report.

The initial step in estimating site-specific EUIs was to assess all available regional and other published EIU data (Taylor and Pratt 1989; Dixon et al. 1992, Vol. 2) that might be applicable to Griffiss AFB (see Section 9.1 for descriptions). After reviewing all sources and matching existing data building types with Griffiss AFB building types, a set of initial EUI values was created. This set of values provides a range of reasonable EUI values within which the site specific values are expected to fall.

Table 9.4 shows the minimum, maximum, and median values derived from the regional and published data that was found to be applicable to Griffiss AFB. The minimum end-use EUIs are $25 \%$ to $90 \%$ of the median and the maximum end-use EUIs range from $110 \%$ to $200 \%$ of the corresponding median. The minimum whotebuilding EUIs are $40 \%$ to $85 \%$ of the median and the maximum whole-building EUIs range from $115 \%$ to $190 \%$ of the corresponding median. The data on commissary, club/dining facilities, and family housing show the best agreement among the regional studies; The EUIs for warehouses exhibit the greatest disparity. 
IABLE 9.4. Regional EUIs (min/median/max) Applied to the Griffiss AFB EUI Analysis

\begin{tabular}{|c|c|c|c|c|c|}
\hline \multirow[b]{2}{*}{ Bullding Type } & \multicolumn{5}{|c|}{ min/median/max end-use EUIs given in $\mathrm{kWh} / \mathrm{ft}^{2}-\mathrm{yr}$} \\
\hline & cooling & Ventilation & Lighting & Refrigerat'n & Other \\
\hline Family Housing & $5 / 6 / 8$ & NA & $0.3 / .7 / 1$ & $0.8 / 1 / 1.4$ & $1 / 1.5 / 2$ \\
\hline Barracks $^{(a)}$ & $10 / 11 / 13$ & $0.5 / 0.75 / 1$ & $2 / 4 / 6$ & $0.5 / 1 / 2$ & $1 / 2 / 3$ \\
\hline Office/Admin. & $10 / 15 / 20$ & $0.75 / 1 / 2$ & $4 / 5.5 / 7$ & $0.5 / 2 / 4$ & $2 / 3.5 / 5$ \\
\hline Commissary & $2 / 2.5 / 3$ & $1 / 1.75 / 2.5$ & $13 / 15 / 17$ & $20 / 23 / 25$ & $7 / 9 / 11$ \\
\hline Club/Dining Hall & $1 / 2 / 3$ & $0.5 / 1 / 1.5$ & $5 / 7 / 9$ & $7 / 8 / 9$ & $30 / 40 / 50$ \\
\hline Hospital & $1 / 2 / 3$ & $1 / 2 / 3$ & $4 / 7 / 10$ & $0.5 / 1 / 1.5$ & $12 / 17 / 22$ \\
\hline Retail Store & $1.5 / 2 / 2.5$ & $0.5 / 1 / 1.5$ & $4 / 7 / 9$ & $1 / 3 / 5$ & $2 / 3 / 4$ \\
\hline Warehouse/Shop & $1 / 2 / 3$ & $0.25 / .5 / 1$ & $1 / 2 / 3$ & $0.5 / 1 / 2$ & $0.75 / 3 / 7$ \\
\hline
\end{tabular}

(a) Barracks without dining.

\subsection{ENERGY USE BY BUILDING TYPE}

Relatively few of the bulldings at Griffiss AFB have electric meters. To determine the conservation potential of measures relating to specific enduse equipment we begin by estimating energy use by building type. This is straightforward in cases where actual building metering data or building type area metering exist. In other cases EUI values are derived by an energy balance method. This procedure accounts for all energy use at the base while apportioning it as accurately as possible to the various buildings and other uses.

Available information on air conditioning, lighting (see Appendixes $A$ and $B$ ) and streetlighting energy consumption allowed these end uses to be separated from the building totals before reconciliation to the feeder totals. The air-conditioning EUI was calculated on a per-building basis, for those buildings with air conditioning. The EUI was then apportioned equally across the building type on a square footage basis. The streetlighting was reduced to a line item total consumption for each feeder. 
Two "figures of merit" were developed to reconcile the building total EUIs with th.? metered feeder totals. One figure measured the EUI's sensitivity to change in relation to difference between the measured feeder totals and the feeder totals calculated by the EUIs. The sensitivity was used to adjust each EUI to achieve the closest match between the measured and calculated feeder totals. The second measure was used to determine the need to disaggregate a building type by feeder, as was the case for the following butlding types: COMCATN, HANGAR, R\&D, HSG-FAM and WHS. During the iterative process of developing the EUIs, it became apparent that several important building types could not be reconciled as a single EUI across all of the feeders. These building types were split and individual EUIs were calculated. Different EUIs for the same building types on different feeders may be caused by hours of operation, intensity of use, installed equipment, building age, or other factors.

Estimates of electric consumption by building type are presented in Table 9.5. Building types split between the feeders are listed with the separated feeders following the bullding type. The electric consumption numbers that are not tied to a specific building (streetights, etc.) are shown with totals only. The last line item is the total of loss in the electric distribution system. Distribution losses are associated with individual buildings roughly in proportion to their energy use.

\subsection{ENERGY-USE INTENSITIES BY END USE}

The electric load is attributed within each building type to several primary end uses. This allocation is based on three types of information: 1) the regional EUI estimates, 2) the Fort Drum EUI analysis (Dixon et al. 1992, Vol. 2), and 3) site-specific data on equipment characteristics, including hours of operation. The available equipment characteristics data for Griffiss AFB included lamp replacement data and the fan, pump and chiller inventory abstracted from the Recurring Work Program database (see Appendixes $A$ and $B)$.

To calculate the end-use EUIs, the air-conditioning EUI calculated in Appendix $A$ was subtracted from the whole-building EUIs shown in Table 9.5. 
IABLE 9.5. Annual Electric Consumption by Building Type and Feeder

\begin{tabular}{|c|c|c|c|c|c|c|c|c|c|c|c|}
\hline & $\begin{array}{c}\text { EUI } \\
\text { suthosf }\end{array}$ & $s v^{k}\left(P_{a}\right)$ & $\begin{array}{c}\mathrm{kWh} \\
5^{4} \mathrm{H}_{3}\end{array}$ & $\begin{array}{l}\text { kWh } \\
\text { sH } 4 \\
\end{array}$ & $\begin{array}{l}k \text { Wh } \\
\text { sty } 5\end{array}$ & $\begin{array}{l}\text { kWh } \\
\text { SW } 6 \\
\end{array}$ & $\begin{array}{l}\text { kWh } \\
\text { SH'] }\end{array}$ & $\begin{array}{l}\text { KWh } \\
\text { SH B } 8\end{array}$ & $\begin{array}{c}\text { kWh } \\
\text { SWL }\end{array}$ & 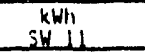 & $\begin{array}{l}k W h \\
5 W 12 \\
5+12\end{array}$ \\
\hline ADMIN & $\begin{array}{l}8.40 \\
6.20\end{array}$ & 2.031 .893 & 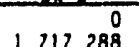 & 448.854 & $\begin{array}{r}0 \\
856,598\end{array}$ & 568.756 & $\begin{array}{l}0 \\
0\end{array}$ & $\begin{array}{l}0 \\
0\end{array}$ & 85.554 & $\begin{array}{l}0 \\
0\end{array}$ & $\begin{array}{l}0 \\
0\end{array}$ \\
\hline BRK & $\begin{array}{l}0.20 \\
9.20\end{array}$ & 198.499 & $1.161,000$ & 2.816 .608 & 70.914 & 198,600 & 0 & 0 & & 0 & 0 \\
\hline $\begin{array}{l}\text { CHAPEL } \\
\text { CLINIC }\end{array}$ & $\begin{array}{r}6.00 \\
35.00\end{array}$ & & & 155.148 & & & 0 & 0 & $\begin{array}{r}1.440 \\
\end{array}$ & $\begin{array}{l}0 \\
0\end{array}$ & $\begin{array}{l}0 \\
0\end{array}$ \\
\hline CLUB & 20.00 & & 0 & & 272.980 & & 0 & 0 & $\begin{array}{r}2.341 .395 \\
0\end{array}$ & 0 & 0 \\
\hline $\begin{array}{l}\text { COM-OUT } \\
\text { COMCATMI }\end{array}$ & $\begin{array}{r}5.44 \\
5.00\end{array}$ & $6090^{\circ}$ & $\begin{array}{r}0 \\
0\end{array}$ & $\begin{array}{r}0 \\
4.320^{\circ}\end{array}$ & 3.563 & & 0 & 0 & 0 & $\begin{array}{l}0 \\
0\end{array}$ & $\begin{array}{l}0 \\
0\end{array}$ \\
\hline COMCAIN(FI) & $\begin{array}{l}1.00 \\
0.00\end{array}$ & 0.090 & 300.0530 & 4.360 & 262.580 & 0 & 0 & 0 & 0 & 0 & 0 \\
\hline COMCATN $(F G)$ & 90.00 & $\begin{array}{r}0 \\
418\end{array}$ & & $\begin{array}{r}0 \\
0\end{array}$ & 0 & 2.977 .560 & 0 & 0 & 0 & 0 & $\begin{array}{l}0 \\
0\end{array}$ \\
\hline DET-RR & $\begin{array}{r}6.00 \\
14.00\end{array}$ & 90.020 & 594.832 & 101.528 & & $\begin{array}{r}418 \\
0\end{array}$ & 0 & 0 & 7.140 & 0 & 0 \\
\hline $\begin{array}{l}\text { OINING } \\
\text { GROCERY }\end{array}$ & $\begin{array}{r}26.50 \\
29.30\end{array}$ & 0 & 201 & 1.321 .926 & 861.250 & 15.582 & 0 & 0 & 126.617 & $\begin{array}{l}0 \\
0\end{array}$ & 0 \\
\hline $\begin{array}{l}\text { GROCERT } \\
\text { FUELOSP }\end{array}$ & $\begin{array}{l}29.50 \\
65.28\end{array}$ & 0 & $\begin{array}{r}1.312,002 \\
0\end{array}$ & & & 477.197 & 0 & 0 & 0 & 0 & 0 \\
\hline HOSPTiL & 38.00 & $\begin{array}{l}0 \\
. \quad 0\end{array}$ & 0 & $239 \begin{array}{r}0 \\
445\end{array}$ & & & 0 & 0 & 183.826 & 0 & $\begin{array}{l}0 \\
0\end{array}$ \\
\hline $\begin{array}{l}\text { Prorel } \\
\text { Hurgan }\end{array}$ & $\begin{array}{r}15.00 \\
4.50\end{array}$ & 145.224 & & $\begin{array}{r}39.495 \\
86.400\end{array}$ & 356.171 & 510.593 & 0 & 0 & 0 & 0 & 0 \\
\hline $\begin{array}{l}\text { Whath(F3) } \\
H S G-F A M(F 8)\end{array}$ & $\begin{array}{l}8.02 \\
3.81\end{array}$ & 0 & 2.001 .391 & & & & $\begin{array}{l}0 \\
0\end{array}$ & 2.553 .556 & $\begin{array}{l}0 \\
0\end{array}$ & $\begin{array}{l}0 \\
0\end{array}$ & $\begin{array}{l}0 \\
0\end{array}$ \\
\hline HSG-FAM (F9) & 5.60 & & & 0 & 0 & 0 & 0 & & 1.894 .726 & 0 & 0 \\
\hline $\begin{array}{l}\text { HSG-FAM } \\
\text { HUT }\end{array}$ & $\begin{array}{l}6.80 \\
6.50\end{array}$ & 1,710 & $\begin{array}{l}0 \\
0\end{array}$ & $\begin{array}{l}62.084 \\
17.550\end{array}$ & $\begin{array}{r}43.812 \\
0\end{array}$ & 0 & 0 & $\begin{array}{l}0 \\
0\end{array}$ & $\begin{array}{l}0 \\
0\end{array}$ & 0 & $\begin{array}{l}0 \\
0\end{array}$ \\
\hline KENNEL & 6.50 & 1.10 & 0 & 12.480 & 0 & 0 & 0 & 0 & 0 & 0 & 0 \\
\hline $\begin{array}{l}\text { IITCHEN } \\
\text { LAB-MED }\end{array}$ & $\begin{array}{l}20.00 \\
17.00\end{array}$ & 332.124 & & & 13,680 & $\begin{array}{l}0 \\
0\end{array}$ & 0 & $\begin{array}{l}0 \\
0\end{array}$ & 40.375 & 0 & $\begin{array}{l}0 \\
0\end{array}$ \\
\hline MUR & 12.00 & 0 & 130.320 & 538.032 & & 0 & 0 & 0 & 11.976 & 0 & $\begin{array}{ll}0 \\
-0\end{array}$ \\
\hline $\begin{array}{l}P L I-B L D \\
\text { PRDCTN }\end{array}$ & $\begin{array}{r}35.75 \\
2.50\end{array}$ & 30.995 & $\begin{array}{l}41.005 \\
0\end{array}$ & & 81.508 & $\begin{array}{r}7.722 \\
0\end{array}$ & 0 & $\begin{array}{r}23,88 ! \\
0\end{array}$ & $\begin{array}{r}21.450 \\
0\end{array}$ & $\begin{array}{l}0 \\
2\end{array}$ & 2.05 .557 \\
\hline$P Q, i p$ & 2.00 & 4.706 & & $9.030^{\circ}$ & 3.326 & 0 & 0 & 890 & 122 & 0 & 0 \\
\hline R8D & $\begin{array}{r}27.38 \\
8.00\end{array}$ & $3,275,798$ & $\begin{array}{l}0 \\
0\end{array}$ & 3.334 .145 & $495.104^{\circ}$ & 0 & $\begin{array}{l}0 \\
0\end{array}$ & $\begin{array}{l}0 \\
0\end{array}$ & $\begin{array}{l}0 \\
0\end{array}$ & 1. $282.28 ?$ & \\
\hline REC & 12.00 & & & 510.252 & 0 & 0 & 0 & 0 & a & 0 & $j$ \\
\hline $\begin{array}{l}\text { RESTRNT } \\
\text { SECURTY }\end{array}$ & $\begin{array}{r}15.00 \\
4.00\end{array}$ & $111.760^{\circ}$ & $\begin{array}{r}195.420 \\
101.652\end{array}$ & $\begin{array}{l}11.750 \\
53.460\end{array}$ & $42.100^{\circ}$ & 8.424 & $\begin{array}{l}0 \\
0\end{array}$ & $\begin{array}{l}0 \\
0\end{array}$ & $\begin{array}{r}0 \\
180\end{array}$ & 0 & $\begin{array}{l}0 \\
3\end{array}$ \\
\hline $\begin{array}{l}\text { Shop } \\
\text { shop }\end{array}$ & 8.30 & 1.055 .154 & 113.137 & 477.756 & 141.681 & 234.483 & 0 & 0 & 0 & 0 & 0 \\
\hline $\begin{array}{l}\text { SHOP-AIR } \\
\text { SHOP-ELC }\end{array}$ & $\begin{array}{l}6.70 \\
7.40\end{array}$ & $\begin{array}{r}2.874 \\
507.159\end{array}$ & $\begin{array}{r}1.279,981 \\
778,421\end{array}$ & $\begin{array}{r}362 \\
0\end{array}$ & $\begin{array}{l}79.348 \\
21.460\end{array}$ & $\begin{array}{r}24.455 \\
203.063\end{array}$ & $\begin{array}{l}0 \\
0\end{array}$ & $\begin{array}{l}0 \\
0\end{array}$ & $\begin{array}{l}0 \\
0\end{array}$ & $\begin{array}{l}0 \\
0\end{array}$ & $\begin{array}{l}0 \\
0\end{array}$ \\
\hline SHOP-HWY & 7.62 & 52,368 & & 0 & & 00.005 & 0 & 0 & 0 & 0 & 0 \\
\hline $\begin{array}{l}\text { SHOP-MV } \\
\text { SHOP- - WPH }\end{array}$ & $\begin{array}{r}11.00 \\
6.20\end{array}$ & 123.473 & & 0 & $\begin{array}{r}0 \\
893\end{array}$ & $\begin{array}{r}496.386 \\
37.777\end{array}$ & $\begin{array}{l}0 \\
0\end{array}$ & $\begin{array}{l}0 \\
0\end{array}$ & $\begin{array}{l}0 \\
0\end{array}$ & $\begin{array}{l}0 \\
0 \\
0\end{array}$ & $\begin{array}{l}0 \\
0\end{array}$ \\
\hline SIMULIR & 79.00 & $\begin{array}{l}436.080 \\
4360\end{array}$ & o & 0 & 0 & 189.995 & $1,587,900$ & 0 & 238.027 & 0 & 0 \\
\hline $\begin{array}{l}\text { STA-UTL } \\
\text { STOR-HZ }\end{array}$ & $\begin{array}{r}0.00 \\
15.00\end{array}$ & & & $\begin{array}{l}0 \\
0\end{array}$ & 31.095 & $248.550^{\circ}$ & $\begin{array}{l}0 \\
0\end{array}$ & $\begin{array}{l}0 \\
0\end{array}$ & $\begin{array}{l}0 \\
0\end{array}$ & $4.290^{\circ}$ & $\begin{array}{l}0 \\
0\end{array}$ \\
\hline STOR-UH & 0.30 & 27.452 & 4.413 & 2.302 & 17.593 & 120 & 0 & 0 & 315 & & 0 \\
\hline TRAING & 9.00 & $\begin{array}{r}242.685 \\
\end{array}$ & $\begin{array}{l}0 \\
0\end{array}$ & 255.204 & 20,736 & $\begin{array}{r}19.656 \\
21139\end{array}$ & 0 & 0 & 10.578 & $0_{0}^{0}$ & $\begin{array}{l}0 \\
0\end{array}$ \\
\hline WHS & 0.50 & $\begin{array}{r}1,966,204 \\
0\end{array}$ & 21.050 & & 139.237 & $\begin{array}{r}211.339 \\
0\end{array}$ & 0 & 0 & $\begin{array}{r}10.578 \\
0\end{array}$ & $\begin{array}{l}0 \\
0\end{array}$ & 0 \\
\hline WHS-CLO (b) & & 262,120 & $200^{0}$ & $38^{\circ}$ & 20800 & 27200 & 0 & $63.072^{\circ}$ & $\begin{array}{r}15.829 \\
122.071\end{array}$ & & \\
\hline 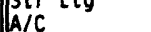 & & 2.664 .593 & & $2,193.387$ & & $2,283,085$ & & & & & \\
\hline Ifro loss & & [., 378 & 115 & 1315.633 & 565.089 & 1091.491 & 220.997 & 259.035 & 639.902 & 1691491 & 265,140 \\
\hline \multirow{3}{*}{\multicolumn{2}{|c|}{$\begin{array}{l}\text { TOTAL } \\
\text { Metered Total } \\
\text { Deita Total } \\
\text { Percent Difference }\end{array}$}} & 14.070 .063 & 10.086 .676 & $13,360.993$ & & & & & & & \\
\hline & & 14.046 .495 & 10.088 .490 & 13.410 .690 & 5.760 .145 & 9.428 .679 & 2.252 .692 & 2.640 .434 & 6.522 .787 & 11.125 .929 & $2.702,660$ \\
\hline & & $\begin{array}{r}23.569 \\
0.28\end{array}$ & $\begin{array}{l}(1,814) \\
0.0 \%\end{array}$ & $\begin{array}{r}149.698) \\
-0.48\end{array}$ & 94.167 & ${ }_{0}^{182}$ & $\begin{array}{r}15,382) \\
-0.22\end{array}$ & $0.0 \%$ & $(2,174)$ & $(3.348)$ & 3.00 \\
\hline
\end{tabular}


The remainder was then split between the end-uses using the information listed above. Further checks were made of the totals of the end-uses by comparing the totals to known data, like the lighting replacement record totals.

In the process of allocating energy by end-use it became apparent that initial site-wide lighting energy estimates (based on regional and Ft. Drum end-use EUIs) and cooling energy estimates (based on installed capacities documented in Appendix $A$ and on the original 600 annual full-load-equivalent [FLE] hours estimate [ASHRAE 1985] for most bullding types) were low. The cooling estimates were increased by adjusting the FLE hours to $800 \mathrm{hr} / \mathrm{yr}$ in most cases (see Appendix $A$ ). The air-conditioning loads on each feeder and the EUIs for each building type were then recomputed to obtain the final values shown in Table 9.5. The lighting EUIs were then revised to reflect a compromise between the initial estimates and the aggregate EUI indicated by the lamp replacement records. The remaining end-use EUIs were then developed by relatively minor adjustment to the initial end-use EUIs.

Table 9.6 presents the results of the electric end-use EUI analysis. EUI estimates are given for all of the major end uses and building types that exist at Griffiss AFB. The "total w/o cooling" column is the same value that appears in Table 9.5 as the whole-building EUI.

Appearance of zero $(0)$ in the table for a minor end-use indicates that the building type in question has too small a component of that end use to be apportioned separately. In such cases the end use component appears as part of "other." The absence of energy consumption in major end uses such as space heating and water heating indicates that the end use is predominately nonelectric. 
TABLE 9.6. Electric EUIs ( $\left(\mathrm{Wh} / \mathrm{ft}^{2}\right.$ ) by Building Type and End Use

\begin{tabular}{|c|c|c|c|c|c|c|c|c|}
\hline B]da. Type & Yent/Fans & Liahtina & Cooling & $\begin{array}{l}\text { Food } \\
\text { Prep. }\end{array}$ & Refrig. & Other & ت̈otal & $\begin{array}{l}\text { Total } w / 0 \\
\text { cooling }\end{array}$ \\
\hline ADMIN & 1.00 & 5.1 & 4.11 & 0.00 & 0.20 & 2.10 & 12.51 & 8.40 \\
\hline ADMIN(F385) & 1.00 & 4 & 2.29 & 0.00 & 0.20 & 1.00 & 8.49 & 6.20 \\
\hline BRK & 1.50 & 4 & 0.65 & 0.20 & 0.92 & 2.58 & 9.85 & 9.20 \\
\hline CHAPEL & 1.00 & 4 & 0.00 & 0.00 & 0.00 & 1.00 & 6.00 & 6.00 \\
\hline CLINIC & 6.00 & 16 & 6.22 & 0.00 & 0.40 & 12.60 & 41.22 & 35.00 \\
\hline CLUB & 3.00 & 10 & 8.81 & 2.00 & 3.00 & 2.00 & 28.81 & 20.00 \\
\hline COM-OUT & 0.00 & 3.5 & 0.00 & 0.00 & 0.00 & 1.94 & 5.44 & 5.44 \\
\hline COMCATN1 & 2.00 & 10 & 3.32 & 0.00 & 0.20 & 2.80 & 18.32 & 15.00 \\
\hline COMCATH(F1) & 2.00 & 6.8 & 8.74 & 0.00 & 0.20 & 1.00 & 18.74 & 10.00 \\
\hline COMCATN(F6) & 12.00 & 25 & 36.02 & 0.00 & 0.20 & 52.80 & 126.02 & 90.00 \\
\hline DET-RR & 1.00 & 5.5 & 0.00 & 0.00 & 0.00 & 0.03 & 6.53 & 6.53 \\
\hline DGR & 2.00 & 8.5 & 4.72 & 0.00 & 2.00 & 1.50 & 18.72 & 14.00 \\
\hline DINING & 4.00 & 11 & 8.81 & 5.00 & 5.00 & 1.50 & 35.31 & 26.50 \\
\hline GROCERY & 4.00 & 14 & 2.44 & 2.50 & 6.00 & 2.80 & 31.74 & 29.30 \\
\hline FUELDSP & 5.00 & 15 & 0.00 & 0.00 & 0.00 & 45.28 & 65.28 & 65.28 \\
\hline HOSPTIL & 8.00 & 18 & 6.22 & 1.00 & 0.50 & 10.50 & 44.22 & 38.00 \\
\hline HOTEL & 3.00 & 5 & 1.50 & 0.50 & 1.00 & 5.50 & 16.50 & 15.00 \\
\hline HA: iAR & 0.50 & 4.5 & 0.15 & 0.00 & 0.00 & 0.50 & 5.65 & 5.50 \\
\hline HAMGAR(F3) & 1.00 & 6 & 0.15 & 0.00 & 0.00 & 1.02 & 8.17 & 8.02 \\
\hline $\begin{array}{l}\text { HSG-FAM (F8) } \\
\text { HSG-FAM (F9) } \\
\text { HSG-FAM } \\
\text { HUT }\end{array}$ & $\begin{array}{l}0.06 \\
0.20 \\
0.13 \\
1.00\end{array}$ & $\begin{array}{r}1.3 \\
2 \\
1.6 \\
4\end{array}$ & $\begin{array}{l}0.00 \\
0.00 \\
0.60 \\
0.23\end{array}$ & $\begin{array}{l}0.45 \\
0.60 \\
0.53 \\
0.00\end{array}$ & $\begin{array}{l}0.85 \\
1.15 \\
1.00 \\
0.00\end{array}$ & $\begin{array}{l}1.15 \\
1.65 \\
3.55 \\
1.50\end{array}(\mathrm{~b})$ & $\begin{array}{l}3.81 \\
5.60 \\
7.41 \\
6.73\end{array}$ & $\begin{array}{l}3.81 \\
5.60 \\
6.81 \\
6.50\end{array}$ \\
\hline KENNEL & 1.50 & 4 & 0.00 & 0.00 & 0.00 & 1.00 & 6.50 & 6.50 \\
\hline KITCHEN & 1.50 & 5.5 & 0.00 & 5.00 & 5.00 & 3.00 & 20.00 & 20.00 \\
\hline LAB-MED & 1.50 & 10 & 6.25 & 0.00 & $\cdot 0.50$ & 5.00 & 23.25 & 17.00 \\
\hline MWR & 1.50 & 7 & 2.27 & 0.15 & 0.25 & 3.10 & 14.27 & 12.00 \\
\hline PLT-BLD & 3.00 & 6 & 0.00 & 0.00 & 0.00 & 26.75 & 35.75 & 35.75 \\
\hline PRDCTN & 0.50 & 1.5 & 0.50 & 0.00 & 0.00 & 0.50 & 3.00 & 2.50 \\
\hline PUMP & 0.00 & 0.1 & 0.00 & 0.00 & 0.00 & 1.90 & 2.00 & 2.00 \\
\hline$R \& D$ & 2.00 & 13 & 11.11 & 0.00 & 0.20 & 12.18 & 38.49 & 27.38 \\
\hline$R \& D(F 1)$ & 1.20 & $\mathbf{5}$ & 5.85 & 0.00 & 0.20 & 1.60 & 13.85 & 8.00 \\
\hline REC & 1.50 & 6 & 1.06 & 0.15 & 0.30 & 4.05 & 13.06 & 12.00 \\
\hline RESTRNT & 2.00 & 7 & 8.81 & 1.00 & 3.00 & 2.00 & 23.81 & 15.00 \\
\hline SECURTY & 0.50 & 3 & 2.52 & 0.00 & 0.00 & 0.50 & 6.52 & 4.00 \\
\hline SHOP & 1.00 & 4.5 & 1.12 & 0.00 & 0.20 & 2.60 & 9.42 & 8.30 \\
\hline $\begin{array}{l}\text { SHOP-AIR } \\
\text { SHOP-ELC } \\
\text { SHOP-HVY } \\
\text { SHOP-HV } \\
\text { SHOP-WPN } \\
\text { SIMULTR } \\
\text { STA-UTL } \\
\text { STOR-HZ } \\
\text { STOR-UH } \\
\text { TRAING } \\
\text { WHS } \\
\text { WHS (F3\&5) } \\
\text { WHS-CLD }\end{array}$ & $\begin{array}{l}1.00 \\
1.00 \\
1.00 \\
0.75 \\
0.80 \\
8.00 \\
0.00 \\
4.00 \\
0.00 \\
1.20 \\
0.50 \\
0.10 \\
0.50\end{array}$ & $\begin{array}{r}4.5 \\
4.5 \\
3.5 \\
5 \\
4.5 \\
15 \\
0 \\
8 \\
0.3 \\
5 \\
3 \\
0.4 \\
\end{array}$ & $\begin{array}{l}0.00 \\
1.46 \\
0.00 \\
0.00 \\
0.88 \\
37.43 \\
0.00 \\
0.00 \\
0.00 \\
0.85 \\
0.51 \\
0.06 \\
0.00\end{array}$ & $\begin{array}{l}0.00 \\
0.00 \\
0.00 \\
0.00 \\
0.00 \\
0.00 \\
0.00 \\
0.00 \\
0.00 \\
0.00 \\
0.00 \\
0.00 \\
0.00\end{array}$ & $\begin{array}{l}0.20 \\
0.20 \\
0.20 \\
0.20 \\
0.20 \\
0.20 \\
0.00 \\
0.00 \\
0.00 \\
0.20 \\
0.00 \\
0.00 \\
19.00 \\
\end{array}$ & $\begin{array}{l}1.00 \\
1.70 \\
2.92 \\
5.05 \\
0.70 \\
55.80 \\
0.00 \\
3.00 \\
0.00 \\
2.60 \\
0.25 \\
0.00 \\
1.01 \\
\end{array}$ & $\begin{array}{r}6.70 \\
8.86 \\
7.62 \\
11.00 \\
7.08 \\
116.43 \\
0.00 \\
15.00 \\
0.30 \\
9.85 \\
4.26 \\
0.56 \\
21.76 \\
\end{array}$ & $\begin{array}{r}6.70 \\
7.40 \\
7.62 \\
11.00 \\
6.20 \\
79.00 \\
0.00 \\
15.00 \\
0.30 \\
9.00 \\
3.75 \\
0.50 \\
2.76 \\
\end{array}$ \\
\hline TOTAL Milh & 6.769 & 29.510 & 15.097 & 1.245 & 2.918 & 20.291 & 75.830 & 60.733 \\
\hline$\left(\begin{array}{ll}(a) & \text { Inclue } \\
\text { b) } & \text { Inclue } \\
\text { canclue }\end{array}\right.$ & $\begin{array}{l}\text { lift stat } \\
\text { DHW at } 2 \text {. }\end{array}$ & $\begin{array}{l}\text { pumping } \\
\text { ft }-y r\end{array}$ & $\begin{array}{l}\text { about } 0 \\
\text { about } 0\end{array}$ & twhlft & & & & \\
\hline
\end{tabular}




\subsection{REFERENCES}

ACEEE 1988, "The Potential for Electricity Conservation in New York State," American Council for an Energy Efficient Economy.

ASHRAE, 1989 Fundamentals, Handbook of the Amer. Soc. of Heating, Refrigeration and Air-conditioning Engrs., Atlanta.

ASHRAE, 1985 Fundamentals, Chapter 25, "Energy Calculations," Handbook of the Amer. Soc. of Heating, Refrigeration and Air-conditioning Engrs., Atlanta.

Balcomb, J., D. Barley, R. McFarland, J. Perry, W. Wray, S. Noll. January 1980. Passive Solar Design Handbook Volume II, Design Analysis, DOE/CS $-1027 / 2$.

Dixon, D. R., P. R. Armstrong, J. R. Brodrick, K. K. Daellenbach, F. V. Di Massa, J. M. Keller, E. E. Richman, G. P. Sullivan, R. R. Wahlstrom. 1992. Fort Drum Integrated Resource Assessment, Volume 2: Basel ine Detail, PNL-8424 Vol. 2, Pacific Northwest Laboratory, Richland, Washington.

Dixon, D. R., P. R. Armstrong, K. K. Daellenbach, J. E. Dagle, F. V. Di Massa, D. B. Elliot, J. M. Keller, E. E. Richman, S. A. Shankle, G. P. Sullivan, R. R. Wahlstrom. 1992. Fort Drum Integrated Resource Assessment, Volume 3: Energy Resource Assessment, PNL-8424 Yol. 3, Pacific Northwest Laboratory, Richland, Washington.

Commercial Energy Demand Modelling Systems (CEDMS), Jerry Jackson Assoc., 1986.

DOE-EIA 1986, "Nonresidential Building Energy Consumption Survey: Commercial Buildings Consumption and Expenditure 1986" (CBECS), Energy Information Administration.

DOE-EIA 1987, "Household Energy Consumption and Expenditure 1987" (RECS), Energy Information Administration.

Massachusetts Electric 1988, "Supplement 3B to Long Range Forecast 3 for the Ten Year Period 1988-1997," Filing Companies: Massachusetts Electric, New England Power Co., Yankee Atomic Electric Co., New England Hydro Transmission Electric Co.

NYSEO 1986, Residential End Use Data Base for Niagara Mohawk Utility District, New York State Energy Office.

NYSEO 1987, Commercial End Use Data Base for Niagara Mohawk Utility District, New York State Energy Office.

Taylor, 2. T. and R. G. Pratt. December 1989. Description of Electric Energy Use in Commercial Buildings in the Pacific Northwest: End-Use Load and Consumer Assessment Program (ELCAP), DOE/BP-13795-22. 
USAF 1978, Engineering Weather Data for Design and Construction, AF Manual 88-29 (also published as U.S. Army TM-5-785), USGPO, Washington, D.C., July 1978.

USAF/LEEP 1990, Real Property Category Codes Listing and Definitions, 28 November 1989; communicated by memo to DEPR from Chief, Requirements Div, Directorate of Programs, Wright-Patterson AFB, 31 January 1990.

Xenergy 1987a, "End Use Energy Consumption for Restaurants, Warehouses, Hotels/Motels, and Miscellaneous Buildings," Xenergy Inc.

Xenergy 1987b, "Study of Energy End Use and Conservation Potential in Selected Segments of the Commercial Class," Xenergy, Inc.

Xenergy 1988, "Characterization of Niagara Mohawk Power Corporation's

Commercial Class: Equipment Saturations, Conservation Measures, and Decision Making Profile," Xenergy, Inc. 


\subsection{SITE DATA SOURCES}

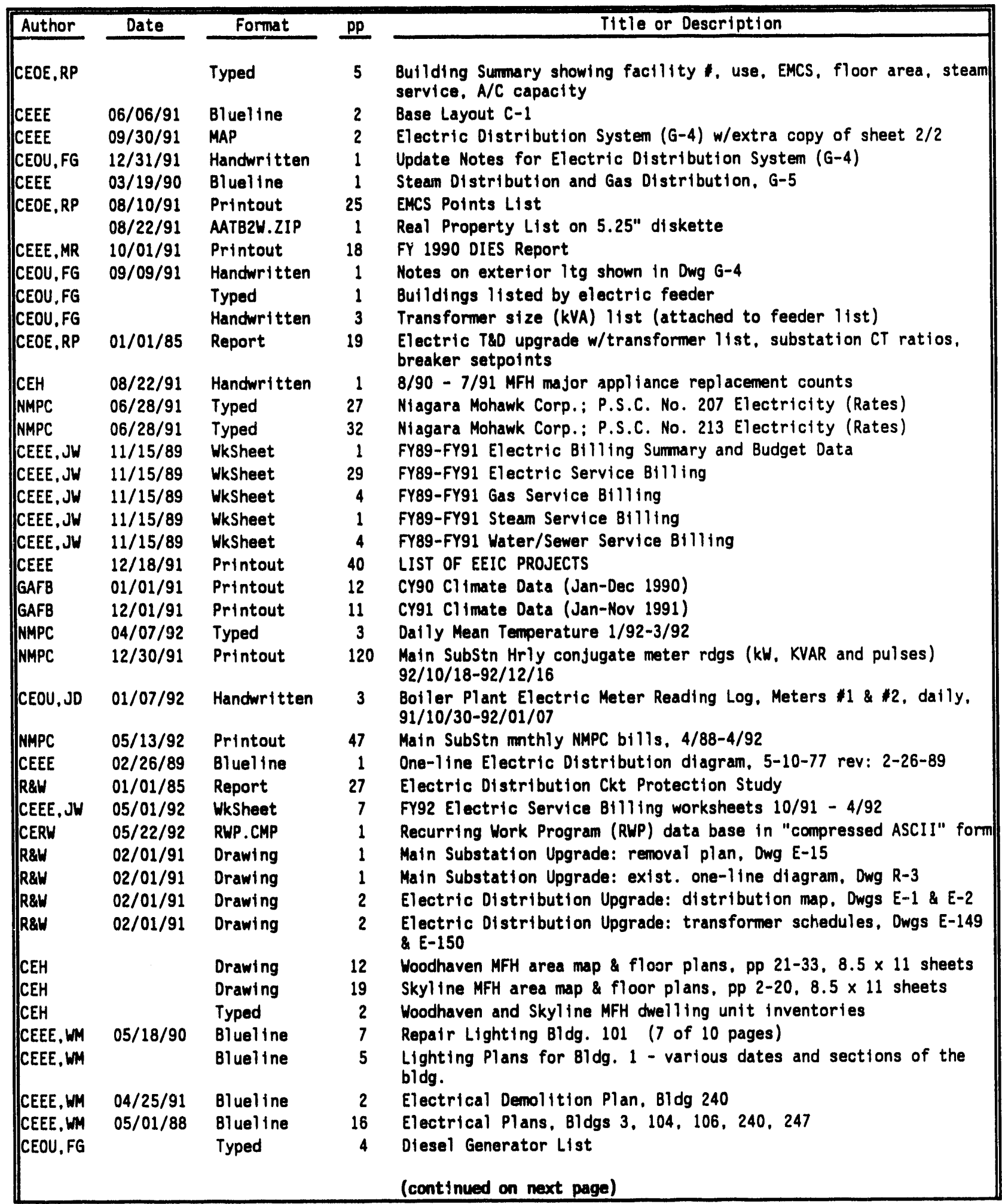




\section{SIIE DATA SOURCES (contd)}

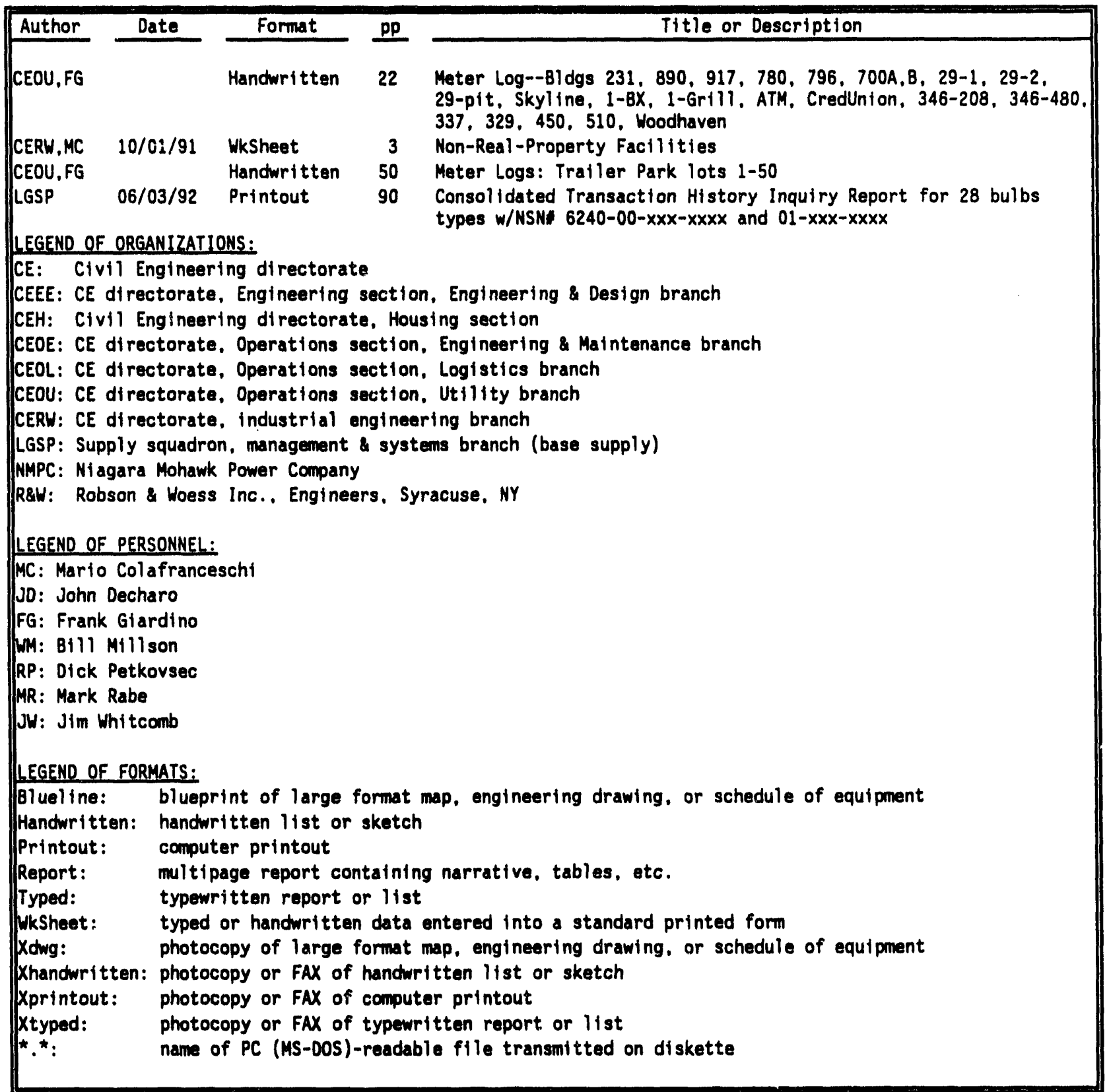


APPENDIX A

AIR-CONDITIONING EOUIPMENT 
APPENDIX A

\section{AIR-CONDITIONING EQUIPMENT}

\section{A.1 REAL PROPERTY LIST AND RECURRING WORK PROGRAM LISTS}

This appendix documents the analysis by which the air-conditioning enduse EUIs were developed. Source data for air-conditioning equipment inventory included the Real Property List (RPL) and the Recurring Work Program (RWP) list.

The RPL contains a list of all of the buildings and the major equipment in each. The air-conditioning $(A / C)$ equipment is grouped by size and type into standard reporting categories with total capacity installed in each building being broken out by equipment type. This aggregation of capacity by equipment type reduces the amount of data storage required but results in some loss of detail. For example, in Building 1 there are 37 tons of $A / C$ equipment in the 5- to 25-ton size category. Obviously, there is more than one $A / C$ unit involved, but the quantity and individual unit sizes cannot be determined.

The RWP is a database used to help track equipment maintenance. It contains equipment data, by building, for each piece of equipment that requires periodic maintenance. Equipment is listed individually, except where multiple identical items are found and a quantity is entered. The RWP database is intended to cover every piece of permanent equipment from the largest chiller to the smallest pump or fan, and is much more extensive than the RPL. The data for the RWP and the database(s) from which much of the RWP data was originally compiled were collected and entered by a number of different people. There are many cases where the same types of equipment are given different names/descriptions. The first task of the RWP analysis process at PNL was to assign new uniform descriptions to all similar equipment. The descriptions assigned by PNL and examples of the RWP descriptions for each are shown in Table A.1. 
IABLE A.1. PNL Descriptions Assigned to RWP Descriptions

\begin{tabular}{|c|c|}
\hline PNL Description & RWP Description \\
\hline \multirow[t]{3}{*}{ A/C Compressor } & $\begin{array}{l}A / C \text { COMPRESSOR } \\
\text { A/C COMPRESSOR }\end{array}$ \\
\hline & A/C COMPRESSOR \\
\hline & A/C COMPRESSOR 2 EA \\
\hline \multirow[t]{10}{*}{ AHU } & $\begin{array}{l}\text { AHU } 10 \text { SOUTH EAST SIDE } \\
\text { AIR HANDLER }\end{array}$ \\
\hline & AIR HANDLER AHU 10 \\
\hline & AIR HANDLER HV-10 \\
\hline & AIR HANDLER HV-9 \\
\hline & AIR HANDLER 1 EA \\
\hline & AIR HANDLER AHU IA \\
\hline & AIR HANDLER UR!IT \\
\hline & AIR HANDLER UNIT \\
\hline & AIR HANOLERS (2EA) \\
\hline & BATTLE MANAGEMENT UNIT AHU \#1 \\
\hline \multirow[t]{3}{*}{ Air Compressor } & AIR COMPRESSOR \\
\hline & AIR COMPRESSOR I EACH \\
\hline & AIR COMPRESSOR EQUIPMENT \\
\hline Air Cooled Chiller & AIR COOLED CHILLER \\
\hline Air Cooled Condenser & $\begin{array}{l}\text { AIR COOLED CONDENSER } \\
\text { AIR COOLED CONDENSER }\end{array}$ \\
\hline \multirow[t]{10}{*}{ B-U GEN. } & $\begin{array}{l}\text { CATERPILLAR } \\
\text { CONSOLID DIESEL }\end{array}$ \\
\hline & CUMMINS \\
\hline & DETROIT DIESEL \\
\hline & INT FERMONT \\
\hline & INT. FERMOUNT \\
\hline & LIBBY \\
\hline & O'BRIEN MACH CO \\
\hline & ONAN \\
\hline & T.J. MANUFACTURE \\
\hline & US MOTORS \\
\hline BLAST HEATER & BLAST HEATER \\
\hline \multirow[t]{2}{*}{ BOILER } & $\begin{array}{l}\text { HOT WATER BOILER } \\
\text { LOW PRESSURE STEAM BOILER }\end{array}$ \\
\hline & STEAM BOILER \\
\hline \multirow[t]{2}{*}{ BOILER - FO } & $\begin{array}{l}\text { HOT WATER BOILER OIL FIRED } \\
L P \text { STEAM BOILER/OIL FIRED }\end{array}$ \\
\hline & LP STEAM BOILER/OIL FIRED \\
\hline BULK STOR. & $\begin{array}{l}\text { BULK STORAGE } \\
\text { A. } 2\end{array}$ \\
\hline
\end{tabular}


IABLE A.1. (contd)

PNL. Description

CABINET HEATER

CATH. PROT.

CENT. OXY. SYSTEM

CENTRIFUGAL CHILLER

CHIGO PNEUMATIC

CHILLER

CLG TOWER

DEEP FAT FRYER

DHW

DHW-FO

DISHWASHER

DISPENSER

DNT

ELEC. BOILER

ELEC. CRANE

ELEC. HOIST

ELEC. PUMP CONTROLS

ELEV. FIXTURES

EMERG. LIGHTS

EXH. FAN

EXT. LIGHTS
RWP Description

CABINET HEATER

CATHODIC PROTECTION

CATHODIC PROTECTION/IMPRESSED

CENTRAL OXYGEN SYSTEM

CENTRIFUGAL CHILLER (1EA)

CENTRIFUGAL CHILLER 2 EACH

CHIGO PNEUMATIC

TRANE AIR HANOLER 1600 CFM

TRANE CHILLER

COOLING TOWER

DEEP FAT FRYER

DOMESTIC WATER HEATER

DOMESTIC H/W HEATER OIL FIRED

DISHWASHER

DISPENSER 2 EA

DNT

ELECTRIC BOILERS

ELECTRIC BRIDGE CRANE

ELECTRIC HOISTS

ELECTRIC PUMP CONTROLS

ELEVATED FIXTURES

ELEVATED FIXTURES PAPI

EMERGENCY LIGHTS

EXHAUST FANS - 6 EACH FLOOR EXHAUST FANS 6 EA

$\begin{array}{ll}\text { APPROACH LIGHTS } & 98 \text { EACH } \\ \text { INSP. SECURITY } & \text { LIGHTS } \\ \text { INSP. SEQUENCED } & \text { FLASHING LTS } \\ \text { INSP. STREET } & \text { LIGHTS } \\ \text { OBSTRUCTION LIGHT } 9 \text { EACH } \\ \text { RUNWAY EDGE LIGHTS }\end{array}$

A. 3 
IABLE A.l. (contd)

PNL Description

RWP Description

FREEZER

FURNACE - FO

FURMACE - GAS

HEAT EXCHR

HOT WATER TANK

ICE MACHINE

INCINERATOR

KITCHEN

O/H HEATERS

PKG. A/C

PKG. CHILLER

POOL BOILER

POUER VENT.

PROT. RELAY

PUMP

PUMP MAINT
FREEZER 2 DR

FREEZER BAR

REACH-IN FREEZER

WARM AIR FURMACE (OIL-FIRED)

WARM AIR FURNACE OIL FIRED

WARM AIR GAS FURNACE

HEAT EXCHANGER

HOT WATER TANK

ICE MACHINES

BASE IMCINERATOR

TREAT FOOD HANDLING FACILITIES

ONH HEATERS CLEAN \& RPL FILTER

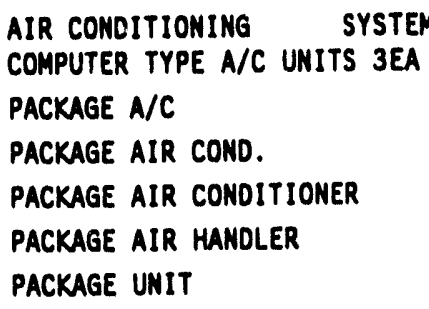

PACKAGED CHILLER

POOL BOILER \& BLONER CHECK

POWER VENTILATOR

PROTECTIVE RELAY CALIBRATION

CHILLED WATER PUMP

CIRCULATING PUMP

CONDENSATE PUMP SINGLE

CONDENSATE PUAP DUPLEX

CONDENSATE PUMP/DUPLEX

CONDENSATE PUAP/SIMGLE

DELUDGE FIRE PUMP

LIQUID TRANSFER PUMP

LIQUID TRANSFER PUMPS

$$
\text { PUMPHOUSE MAINTENANCE }
$$$$
\text { PURGE PUMPS }
$$

A. 4 
IABLEA.1. (contd)

PNL Description

REAO METERS

REC. METER

REFRIG.

SAMO FILTER

SEC. ALARM

SERVICE ST. MAINT.

SEMAGE EJECTOR

SEMAGE L/S ALARM CHECKS

SOL. INJECTION SYS.

TIME CLOCKS

TRAFFIC LIGHT

TRAMSFMR

TRANSPONDER MAINT

TRENCH HEATER
RUP Description

READ METERS

RECORDING METERS

1 EACH

REACHIN REFRIGERATOR REFRIGERATION EQUIPMENT 10 EA.

WALKIN REFER

SUBSURFACE SAND FILTER

SECURITY INTRUSION ALARMS SECURITY ANO INTRUSION ALARM

SERVICE STATION MAMTENANCE SERVICE STATION MAINT

SEMAGE EJECTOR

SEWAGE L/S ALARM CHECKS

SOLUTION INJECTION SYSTEM

TIME CLOCKS

TRAFFIC LIGHT

ELECTRIC VAULT EXTERIOR DIST. SYSTEM EXTERIOR POWER DIST. SYSTEM EXTERIOR POUER OISTRIBUTION EXTERIOR VAULT 10 EACH EXTERIOR VAULT TRANSFORMER EXTERIOR VAULT TRANSFORMERS INTERIOR VAULT TRANSFORMER INTERIOR VAULT TRANSFORMERS INTERIOR VAULTS

TRANSPONDER MAINT TRANSPONOER MAINTENANCE

TRENCH HEATER 
The RPL database is not entirely complete and up-to-date; neither is the RWP database. However, together the two databases appear to provide a complete picture of the installed $A / C$ equipment inventory. The data was combined in a number of steps. First, the two data sets were combined and compared by individual building. All equipment was kept which appeared in one dataset and not the other to ensure a complete set of data. Next, the equipment that appeared in both datasets was inspected for accuracy. For example, in many cases the aggregated RPL data was broken down into individual pieces of equipment in the RWP. In such cases, the RWP was considered more accurate and the RPL data was ignored. In other cases, identical equipment would show up in both datasets, but the installation date on one would be much older (or an obvious defaulted value 1ike 01/01/50) while the other would have a more reasonable date. A third pass was made through any remaining ambiguous data and a judgment call was made whether to keep or reject each item.

\section{A.2 AIR-CONDITIONING EOUIPMENT}

The combined data was sorted and all of the air-conditioning equipment was copied to a separate equipment listing. This list is shown in Table A.2 by building number. The air-conditioning equipment was broken down into eight types which are defined at the bottom of the table. The PNL description column is a combination of the descriptions assigned to the RWP data (described above) and the RPL descriptions. RPL data is denoted by the suffix "-RPL" attached to the end of the description. There are also two formats for the date installed column. The RPL lists only the last two digits of the year when the equipment was installed, while the RWP uses a yymmdd format.

A short program (CHILL.BAS) was written to generate a 1 ist of aggregate connected loads in each building. The coefficient of performance (COP) of the equipment was based on the year of installation and used data developed for FEDS Leve1 1. Figure A.1 shows COP a a function of the age of the equipment. The COPs for the equipment in Table A.2 were interpolated from this data. Any equipment older than 1970 was assumed to have the 1970 COP and any equipment newer than 1990 was assumed to have the 1990 COP. 
IABLEA.2. Air-Conditioning Equipment by Butlding

\begin{tabular}{|c|c|c|c|c|c|c|}
\hline $\begin{array}{l}\text { Bidg. } \\
\text { No. }\end{array}$ & $\begin{array}{l}\text { Bldg. } \\
\text { Type }\end{array}$ & $\begin{array}{c}\text { A/C } \\
\text { Type [a] }\end{array}$ & PNL Description & Capacity & Units & $\begin{array}{c}\text { Date } \\
\text { Installed [b] }\end{array}$ \\
\hline \multirow[t]{11}{*}{1} & SHOP-ELEC & $T$ & CENTRIFUGAL CHILLER & 132 & TON & 500101 \\
\hline & & 1 & CENTRIFUGAL CHILLER & 185 & TON & 500101 \\
\hline & & 3 & Air Cooled Condenser & 3 & TON & 500101 \\
\hline & & 3 & Atr Cooled Condenser & 10 & TON & 841022 \\
\hline & & 3 & Alr Cooled Condenser & 10 & TON & 850101 \\
\hline & & 3 & Alr Cooled Condenser & 15 & TON & 841022 \\
\hline & & 3 & Air Cooled Condenser & 15 & TON & 850101 \\
\hline & & 4 & A/C Compressor & 75 & TON & 500101 \\
\hline & & 6 & PKG. A/C & 3 & TON & 860901 \\
\hline & & 6 & PKG. A/C & 10 & TON & 841022 \\
\hline & & 7 & PKG. A/C & 23 & TON & 600101 \\
\hline \multirow[t]{4}{*}{2} & WHS & 3 & $A / C$ PLT 25-100 TN -RPL & 100 & TON & 80 \\
\hline & & 4 & A/C PLT OV $100 \mathrm{TH}-\mathrm{RPL}$ & 100 & TON & 59 \\
\hline & & 6 & A/C PLT 5 TO 25 TN-RPL & 35 & TON & 53 \\
\hline & & 8 & A/C HINDOW UNITS -RPL & 15 & TON & 89 \\
\hline \multirow[t]{5}{*}{3} & RED & 2 & A/C PLT OV 100 TN -RPL & 1.420 & TON & 68 \\
\hline & & 3 & A/C PLT 25-100 TH -RPL & 220 & TON & 80 \\
\hline & & 6 & A/C PLT 5 TO 25 TN-RPL & 155 & TON & 79 \\
\hline & & 6 & A/C PLT, LS 5 TN -RPL & 6 & TON & 80 \\
\hline & & 8 & A/C WINDOW UNITS -RPL & 2 & TON & 87 \\
\hline \multirow[t]{2}{*}{14} & ADMIN & 3 & A/C PLT 25-100 TN -RPL & 40 & TON & 53 \\
\hline & & 6 & A/C PLT 5 TO 25 TH-RPL & 15 & TON & 64 \\
\hline 14 & ADMIN & 8 & A/C WINDOW UNITS -RPL & 16 & TON & 79 \\
\hline 19 & ADMIN & 6 & A/C PLT 5 TO 25 TH-RPL & 5 & TON & 64 \\
\hline 40 & AnNIN & 3 & A/C PLT 25-100 TN -RPL & 60 & TON & 62 \\
\hline 42 & ADMIN & 3 & A/C Compressor & 5 & TON & 500101 \\
\hline 44 & BRK/ADM & 3 & A/C Compressor & 25 & TON & 830101 \\
\hline 45 & SECURTY & 6 & A/C PLT 5 TO 25 TN-RPL & 20 & TON & 81 \\
\hline 97 & COMCATH & 6 & A/C PLT, LS 5 TH $-R P L$ & 1 & TON & 89 \\
\hline \multirow[t]{3}{*}{100} & HANGAR & 6 & A/C PLT 5 TO 25 TH-RPL & 40 & TON & 55 \\
\hline & & 6 & A/C PLT, LS 5 TH $-R P L$ & 4 & TON & 55 \\
\hline & & 8 & A/C WINDOW UNITS -RPL & 3 & TON & 90 \\
\hline 101 & HANGAR & 6 & A/C PLT 5 TO 25 TN-RPL & 53 & TON & 71 \\
\hline
\end{tabular}

\section{A.7}


IABLE A.2. (contd)

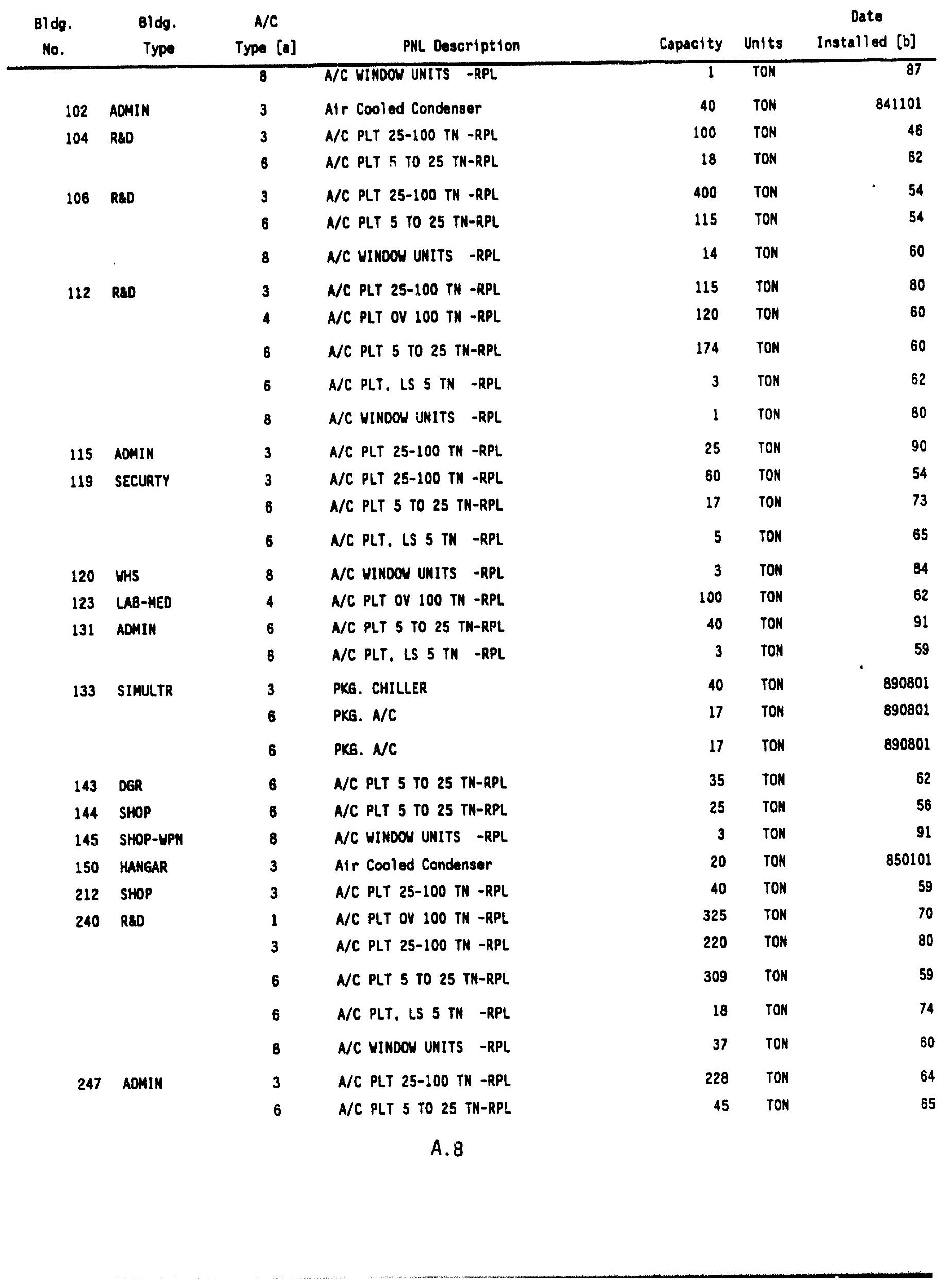


TABLE A.2. (contd)

\begin{tabular}{|c|c|c|c|c|c|c|}
\hline $\begin{array}{l}\text { Bldg. } \\
\text { No. }\end{array}$ & $\begin{array}{l}\text { Bldg. } \\
\text { Type }\end{array}$ & $\begin{array}{c}\text { A/C } \\
\text { Type [a] }\end{array}$ & PML Description & Capacity & Units & $\begin{array}{c}\text { Date } \\
\text { Installed [b] }\end{array}$ \\
\hline \multirow[t]{2}{*}{272} & DINING & 6 & A/C PLT 5 TO 25 TK-RPL & 25 & TON & 70 \\
\hline & & 8 & A/C WINDOW UNITS -RPL & 9 & TON & 70 \\
\hline \multirow[t]{4}{*}{301} & ADMIN & 3 & Air Cooled Condenseir & 3 & TON & 500101 \\
\hline & & 4 & CHILLER & 80 & TON & 890101 \\
\hline & & 6 & PKG. A/C & 10 & TON & 600101 \\
\hline & & 6 & PKG. A/C & 10 & TON & 860901 \\
\hline \multirow[t]{2}{*}{302} & COMCATN & 6 & A/C PLT 5 TO 25 TN-RPL & 67 & TON & 55 \\
\hline & & 6 & A/C PLT, LS 5 TN $\quad-$ RPL & 1 & TON & 83 \\
\hline \multirow[t]{3}{*}{311} & ADMIN & 3 & Air Cooled Chiller & 4 & TON & 850101 \\
\hline & & 3 & Air Cooled Condenser & 4 & TON & 830801 \\
\hline & & 7 & PKG. A/C & 40 & TON & 830801 \\
\hline \multirow[t]{2}{*}{324} & WHS-CLD & 3 & A/C Compressor & 10 & TON & 500101 \\
\hline & & 3 & A/C Compressor & 40 & TON & 500101 \\
\hline 329 & DGR & 6 & A/C PLT 5 TO 25 TIN-RPL & 10 & TON & 82 \\
\hline 346 & GROCERY & 3 & A/C PLT 25-100 TN -RPL & 100 & TON & 76 \\
\hline 400 & REC & 6 & A/C PLT 5 TO 25 TN-RPL & 35 & TON & 68 \\
\hline \multirow[t]{3}{*}{428} & ADMTY & 3 & A/C PLT 25-100 TN -RPL & 33 & TON & 91 \\
\hline & & 6 & A/C PLT 5 TO 25 TN-RPL & 25 & TON & 74 \\
\hline & & 8 & A/C WINDOW UNITS -RPL & 1 & TON & 53 \\
\hline 434 & SECURTY & 6 & A/C PLT, LS 5 TN $-R P L$ & 2 & TON & 88 \\
\hline 435 & TRAING & 8 & A/C WINDOY UNITS -RPL & 5 & TON & 96 \\
\hline 436 & TRAING & 8 & A/C WINDOW UNITS -RPL & 3 & TON & 90 \\
\hline \multirow[t]{2}{*}{439} & MWR & 3 & A/C PLT 25-100 TN -RPL & 39 & TON & 72 \\
\hline & & 6 & A/C PLT 5 TO 25 TN-RPL & 11 & TON & 72 \\
\hline 443 & DINING & 3 & A/C PLT 25-100 T'N -RPL & 100 & TON & 87 \\
\hline 446 & TRAING & 6 & A/C PLT, LS 5 TII $-R P L$ & 4 & TON & 78 \\
\hline 447 & TRAING & 6 & A/C PLT, LS 5 TIY - RPL & 4 & TON & 78 \\
\hline 450 & BRK/ADM & 8 & A/C WINDOW UNITS -RPL & 3 & TON & 91 \\
\hline 482 & MWR & 3 & A/C PLT 2;-100 TH -RPL & 25 & TON & 75 \\
\hline \multirow[t]{2}{*}{504} & COMCATK & 4 & $A / C$ Comp.essor & 80 & TON & 500101 \\
\hline & & 6 & A/C PLT 5 TO 25: TN-RPL & 13 & TGN & 81 \\
\hline \multirow[t]{3}{*}{510} & HOSPITL & 1 & CENTRIFUGAL CHIILLER & 325 & TON & 730101 \\
\hline & & 6 & PKG. A/C & 2 & TON & 900101 \\
\hline & & 7 & PKG. A/C & 235 & TON & 750101 \\
\hline 520 & MWR & 6 & A/C PLT 5 TO 25 TN-RPL & 20 & TON & 62 \\
\hline 700 & COMCATN & 3 & A/C PLT 25-100 TN -RPL & 266 & YON & 82 \\
\hline
\end{tabular}


IABLE A.2. (contd)

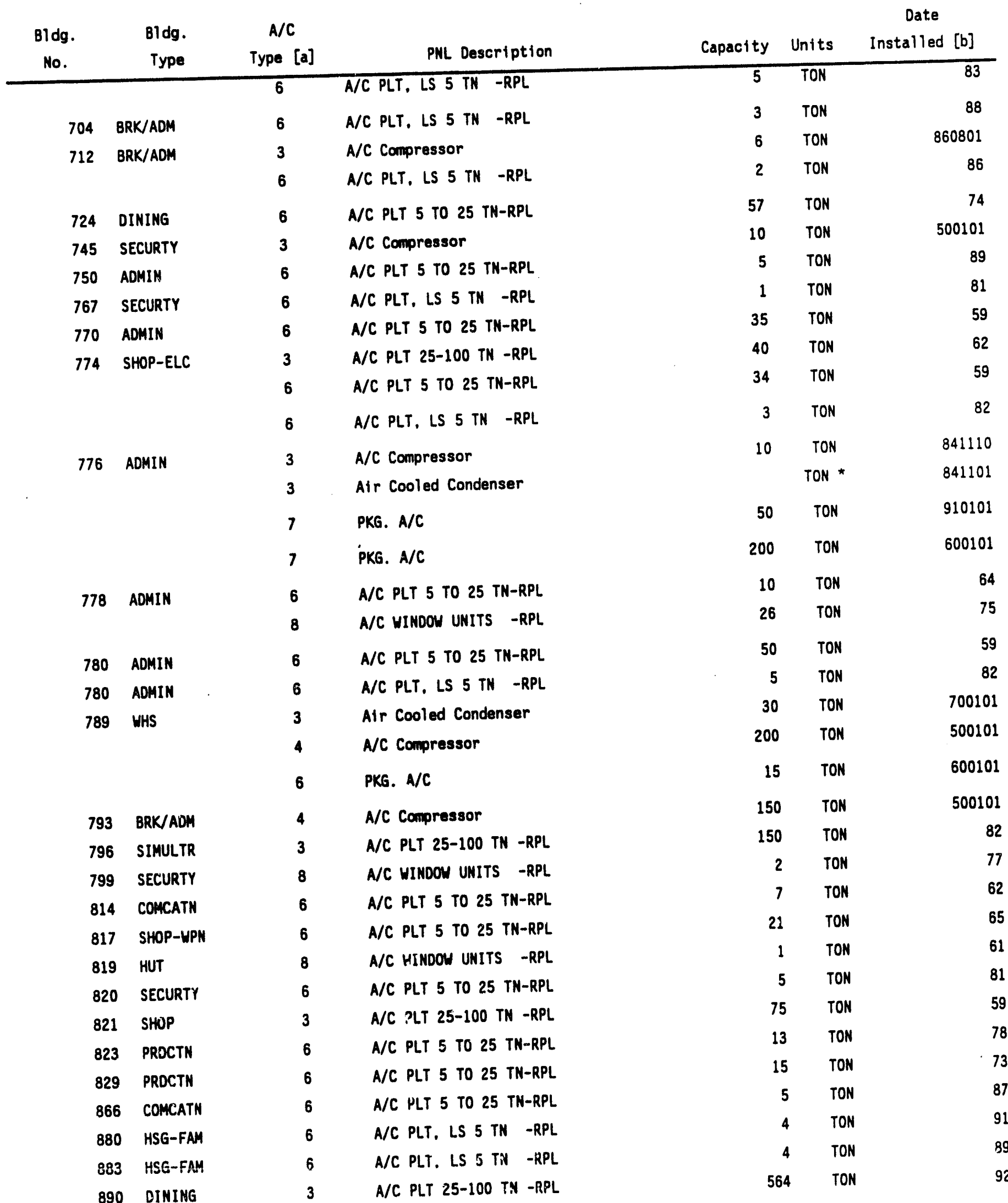


IABLE A.2. (contd)

\begin{tabular}{|c|c|c|c|c|c|c|}
\hline $\begin{array}{l}\text { Bldg. } \\
\text { No. }\end{array}$ & $\begin{array}{l}\text { Bldg. } \\
\text { Type }\end{array}$ & $\begin{array}{c}A / C \\
\text { Type [a] }\end{array}$ & PNL Description & Capacity & Units & $\begin{array}{c}\text { Date } \\
\text { Installed [b] }\end{array}$ \\
\hline 917 & PRDCTN & 4 & A/C Compressor & 160 & TON & 500101 \\
\hline 3007 & HSG-FAM & 6 & A/C PLT, LS 5 TN - RPL & 3 & TON & 89 \\
\hline
\end{tabular}

[a] A/C Types:
1) Small Centrifugal
2) Large Centrifugal
3) Small Reciprocating
4) Large Reciprocating
6) Small Packaged Unit
7) Large Packaged Unit
8) Room/Window Unit

[b] Date Installed: Format depends on origin of data: yy-mm-dd is from Recurring Work Program, yy is from Real Property List. 


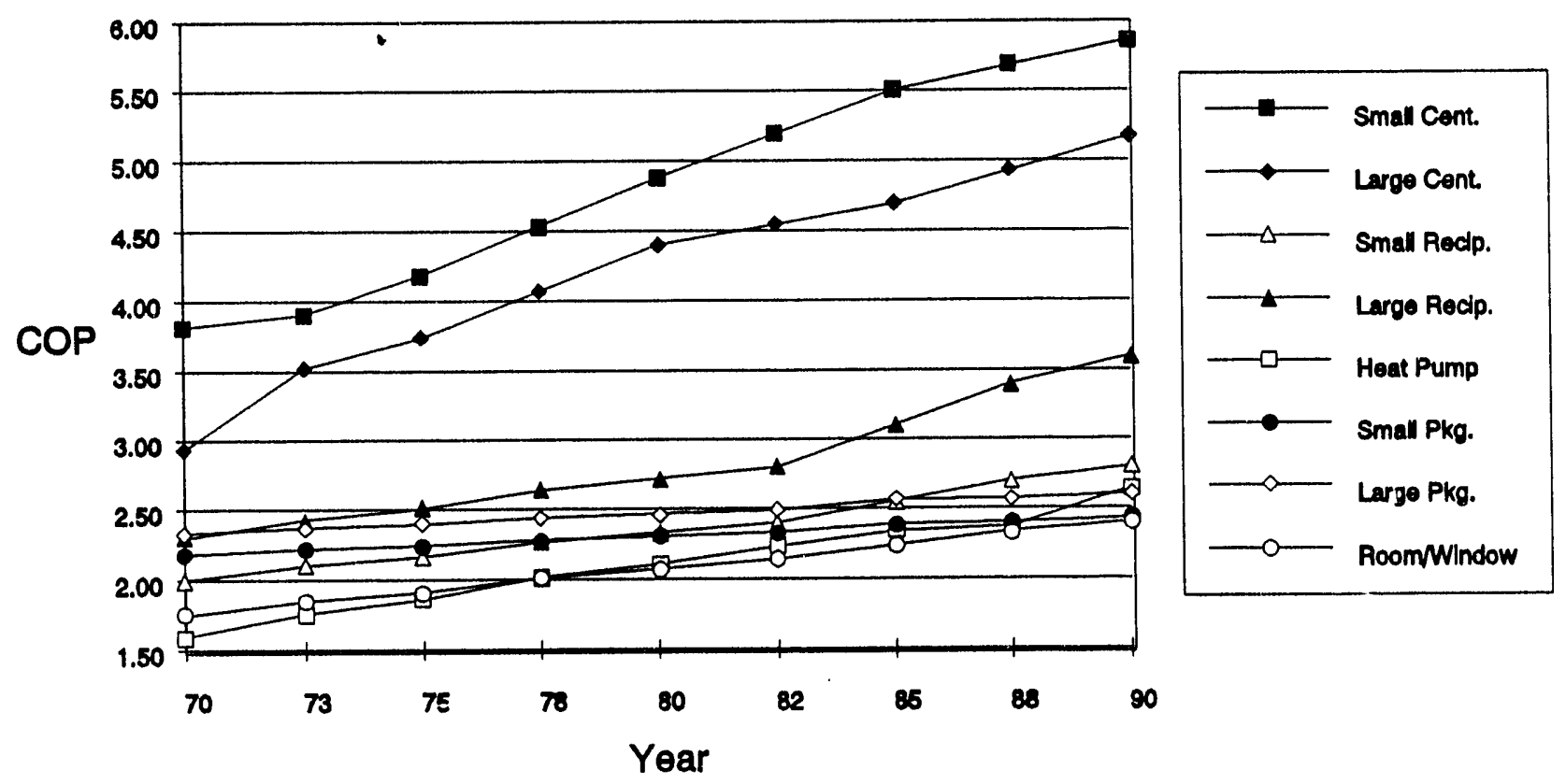

FIGURE A.1. A/C Efficiency as a Function of Year Built

Output of the program was an aggregate power density for $A / C$ equipment in each building as shown in Table A.3. Given the nature of the data (e.g., unknown building envelope characteristics) and the many variables involved with estimating the hours of operation, the equipment was assumed to operate an average of 800 full-load-equivalent (FLE) hours per year (ASHRAE 1985). Also included in Table $A .3$ are the building age and floor area $\left(\mathrm{ft}^{2}\right)$ and aggregate $A / C$ equipment capacity. The $A / C$ EUI is calculated by dividing the kWh by the building area. The remaining columns provide additional detail about the installed capacity by indicating the count and average capacity for each $A / C$ type.

The A/C EUI can be reported as an average EUI for all buildings of a given type or for only those buildings that have some air conditioning. Table A.4 gives the results of aggregating the Table A.3 data by building type. Total Area is the aggregate area of all Griffiss AFB buildings of the 


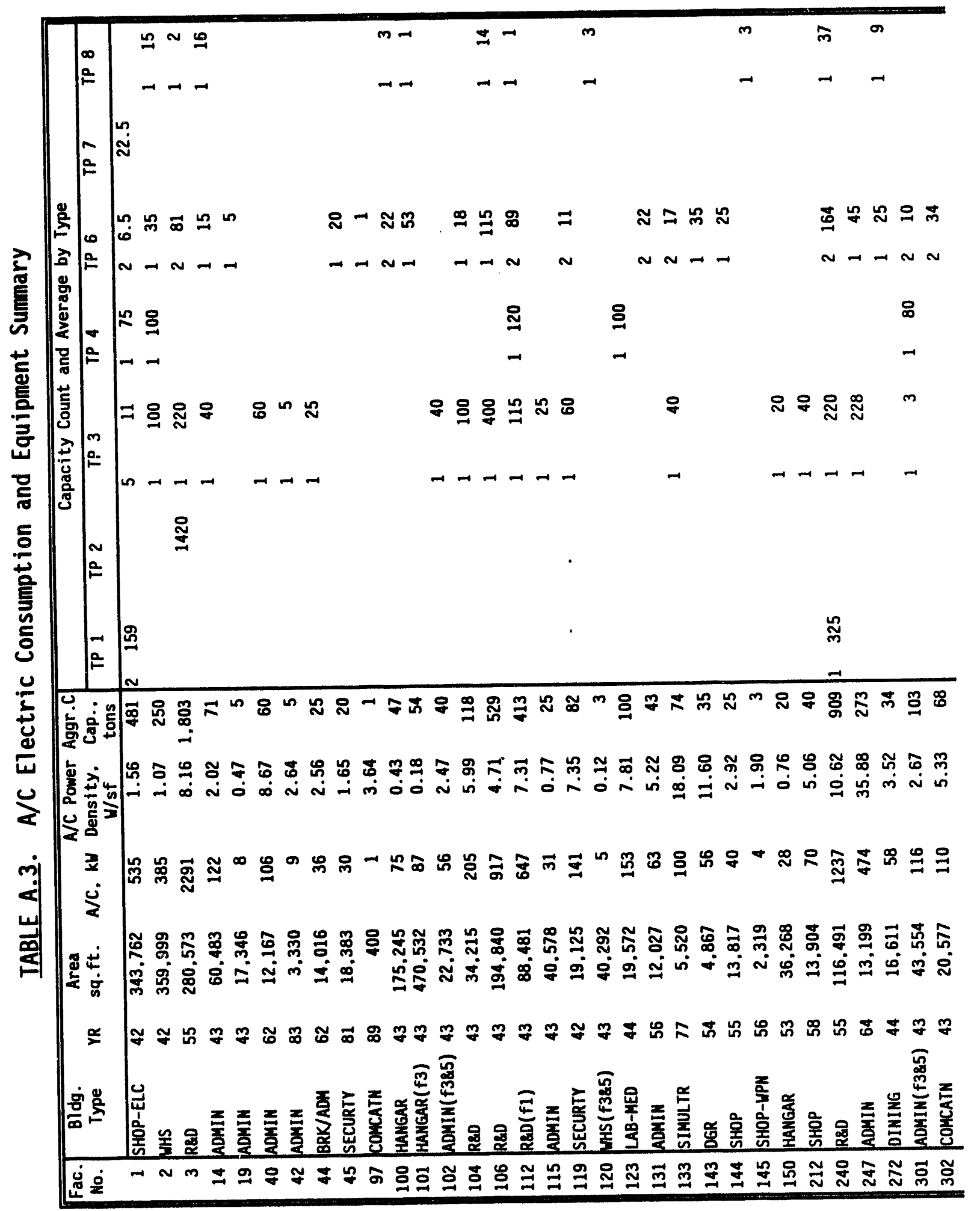




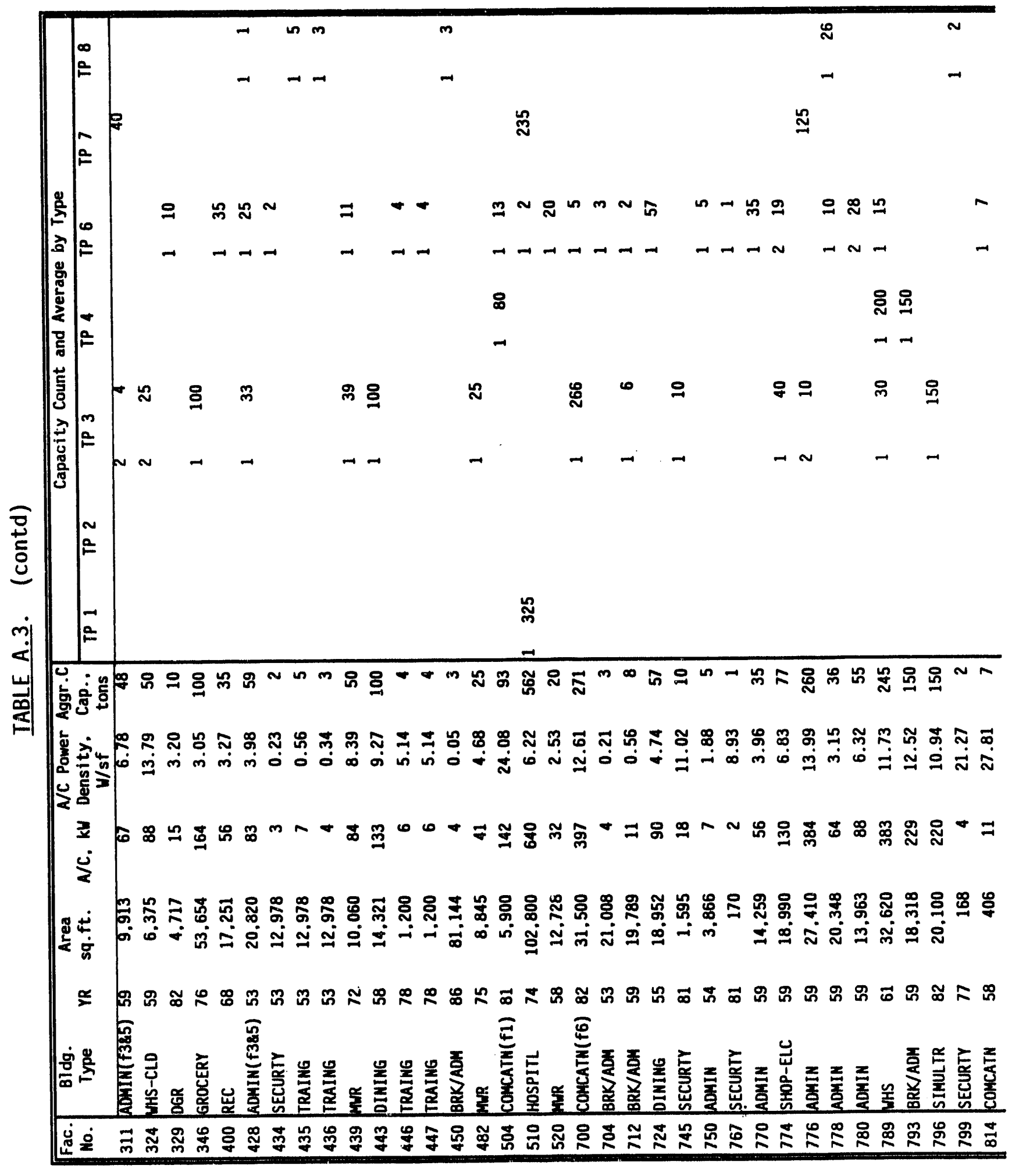




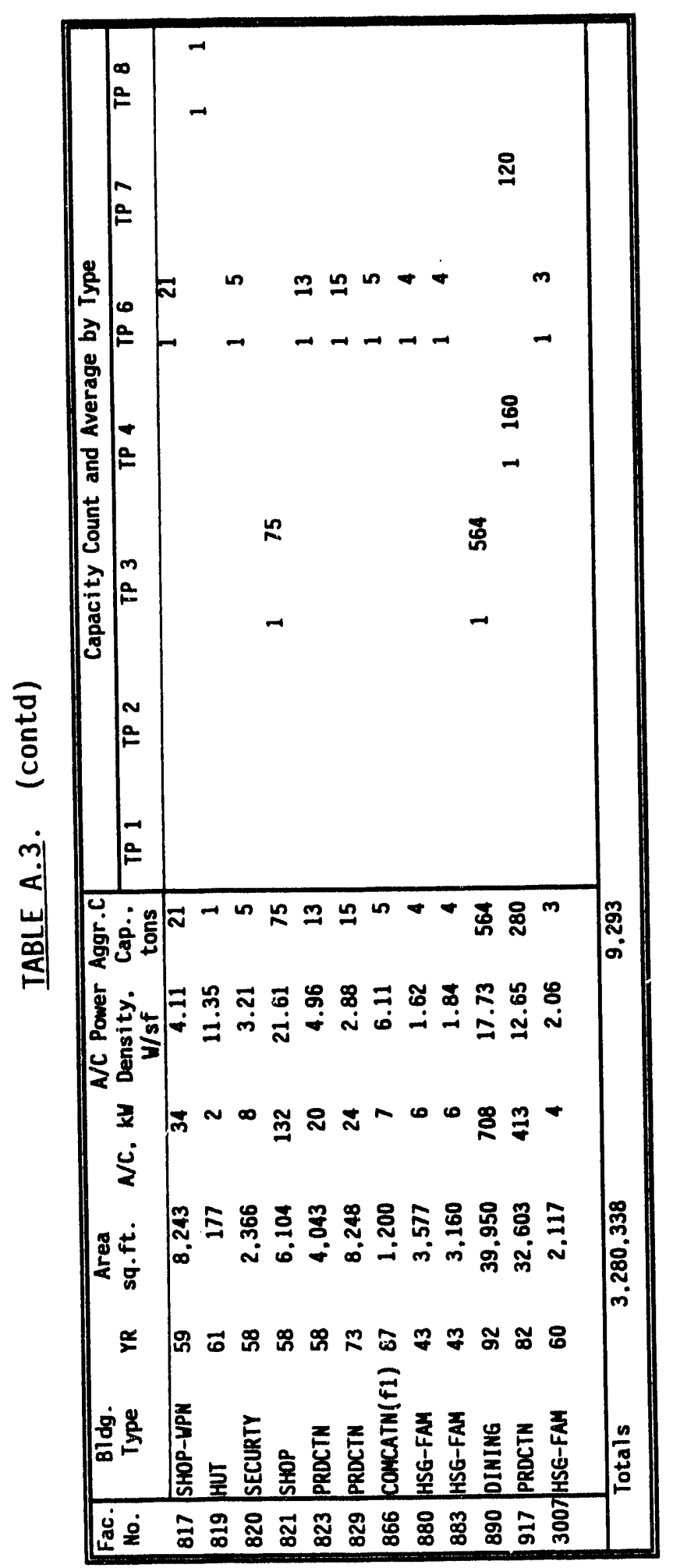

A. 15 


\section{IABLE A.4. Air-Conditioning Energy-Use Intensities by Building Type}

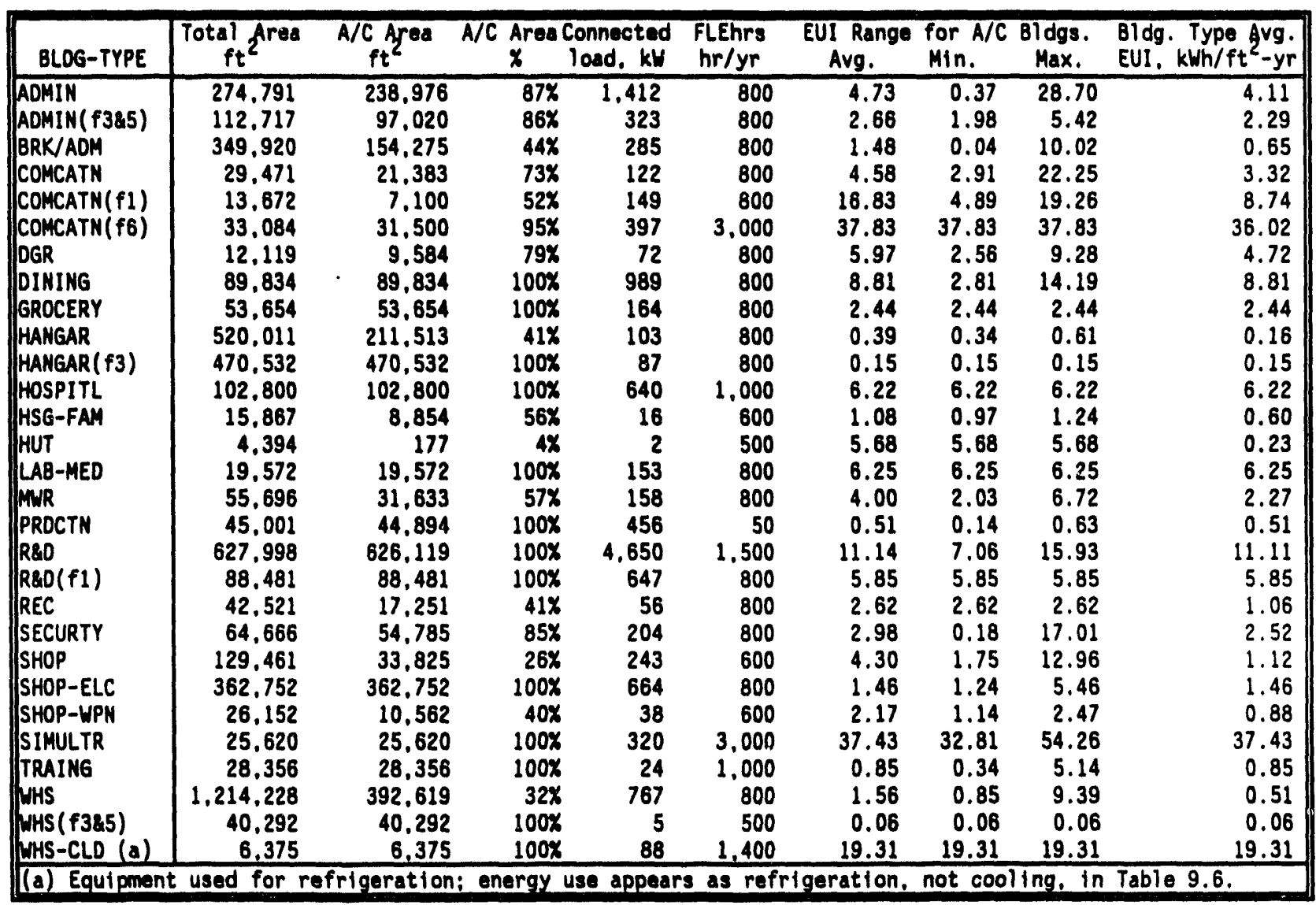


indicated building type. $A / C$ area is the area of the subset of buildings that are at least partly air-conditioned. Percent $A / C$ is the $A / C$ area divided by the total area, or the percentage of the total area represented by airconditioned buildings. As shown, eight of the building types are completely air-conditioned and several others are more than $75 \%$ air-conditioned. The FLE hours for each building type are based on (ASHRAE 1985), except for buildings with large internal gains or long hours of operation to which larger FLE hours have been assigned. The A/C EUI is an area-weighted average of all of the EUIs for each building type shown in Table A.3. "Max EUI" and "MIN EUI" are the maximum and minimum EUIs for each building type. In several cases the average, maximum and minimum are identical, indicating that there is only one building of that type that is air-conditioned. The last column shows the product of $A / C$ penetration and $A / C$ EUI (i.e., the $A / C$ EUI with respect to the total area for the indicated building type). 
APPENDIX B

LAMP REPLACEMENT RECORDS 


\section{APPENDIX B}

\section{LAMP REPLACEMENT RECORDS}

Lamp replacement records were used to approximate the electric energy used for lighting. Records were obtained from the base central supply for National Stock Number (NSN) Class 6240, which covers all lamps and bulbs, in the form of a supply transaction record. With a copy of the National Stock catalog for class 6240, bulb type, wattage and average life were assigned to each stock number. Standard magnetic ballast consumption was added for the fluorescent lamps. The number of each type was totaled for a complete year (1990) and these are shown in Table B.1. The records cover fluorescent and incandescent lighting only, there was no information on high-intensity discharge (HID) (high/low pressure sodium, mercury vapor, metal halide) bulbs. Unfortunately, these bulb types are the majority of the exterior lighting as well as some of the warehouse, hangar, and shop lighting types.

The last column in Table B.l is the calculated energy consumption, obtained by multiplying the first three columns and dividing by $1,000 \mathrm{~W} / \mathrm{kW}$. This value assumes that all of the lamps are replaced at the average life.

There are several factors that can affect the total lighting consumption, including premature bulb failure (for whatever reason), group relamping or other replacement prior to the average lifetime, and the possibility that some bulbs are purchased outside the central supply system and are not included in these records. The iast item is of particular importance in the family housing areas, since the occupants are generally responsible for replacing bulbs. Although bulbs are avallable from the housing office, which presumably purchases through the central supply system, it is questionable how many residents do this rather than purchase bulbs themselves. Since none of the HID lamps are in the central supply records, they are also purchased outside of central supply. There are also some bulbs (cold cathode lamps in at least one Rome Lab bldg.) being "recycled" due to 
IABLE B.1. Lamp Replacement Records for 1990

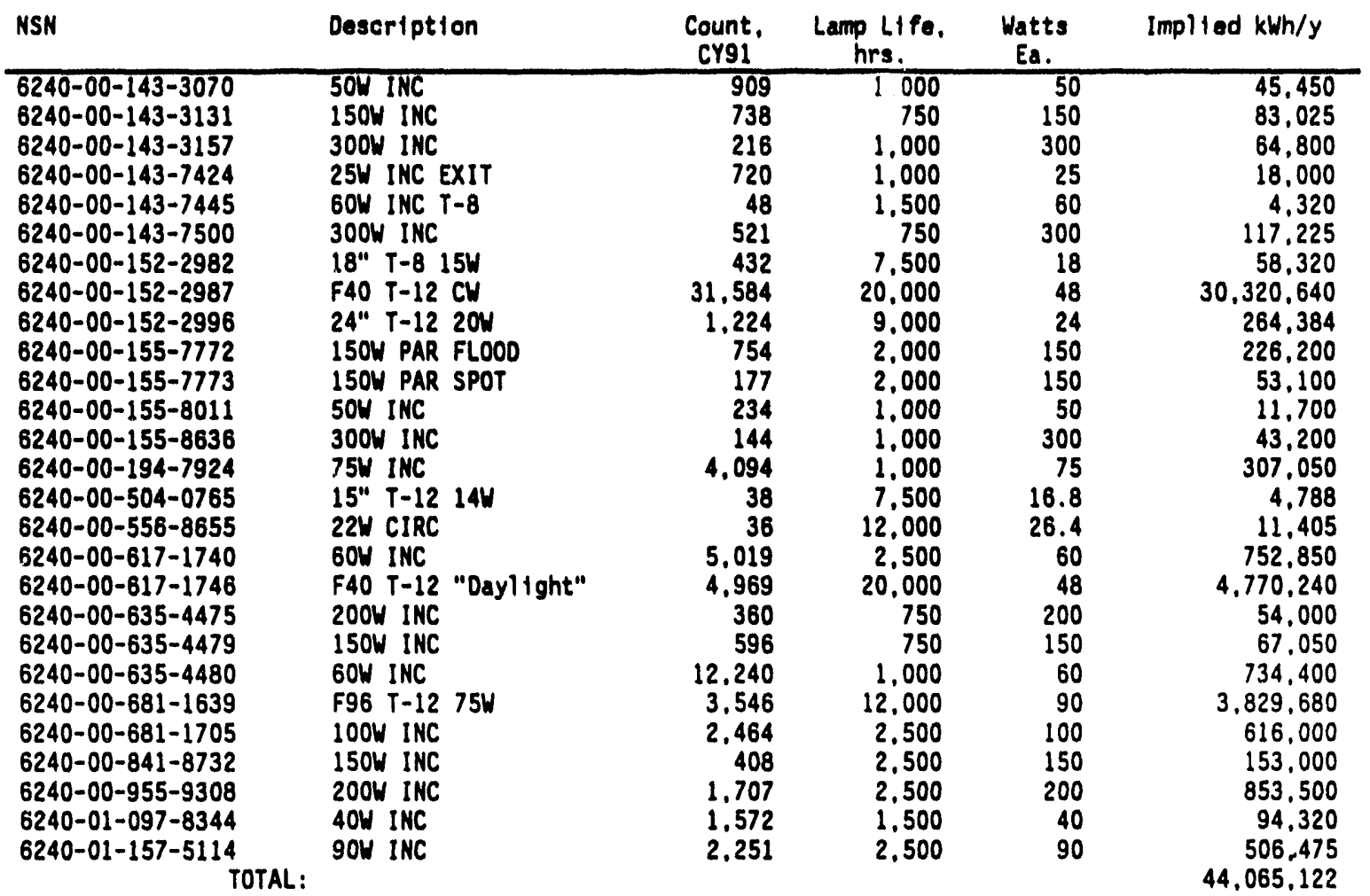

their high cost. The cold cathode lamp fixtures are slowly being replaced, and as each fixture is removed, the bulbs are stored for use in the remaining fixtures.

A comparison of the data from a similar study at Fort Drum shows good comparison between the Griffiss lighting consumption and that of the old post commercial buildings at Fort Drum. Since the two building stocks are similar in age and construction, the data was used in the baseline. 
APPENDIX C

DOMESTIC REFRIGERATION 
APPENDIX C

\section{DOMESTIC REFRIGERATION}

There are 735 family housing units at Griffiss AFB with one full-size residential refrigerator each. In addition, there is a compact refrigerator in every barracks room. The number of barracks rooms was estimated from inspection of three barracks buildings $(B / 438,448,450)$. In these buildings the number of rooms was counted. The area of each of the three butldings was divided by the number of rooms, giving an average of $460 \mathrm{ft}^{2}$ per room. The total barracks area was then divided by 460 , giving a total of 760 compact refrigerators. There are also refrigerators in the breakrooms of almost all of the other buildings on base.

Energy consumption for typical refrigerators is assumed to be 1,300 $\mathrm{kWh} / \mathrm{yr}$ and $430 \mathrm{kWh} / \mathrm{yr}$ for full-size and compact refrigerators, respectively. Table C.1 shows the electric consumption based on these figures. It is assumed that the average commercial building with a breakroom has $0.2 \mathrm{kWh} / \mathrm{ft}^{2}-\mathrm{yr}$ of electrical use due to refrigerators, calculated by assuming 1 breakroom per 10,000 $\mathrm{ft}^{2}$ and approximately $0.1 \mathrm{kWh} / \mathrm{ft}^{2}-\mathrm{yr}$ for vending machines.

IABLE C.1. Electric Consumption for Refrigeration in Barracks and Family Housing

\begin{tabular}{lrrr}
\multicolumn{1}{c}{ Size } & Count & kWh Each & kWh Total \\
\hline Full-Size & 735 & 1,300 & 955,500 \\
Compact & 760 & 430 & 326,800 \\
Totals & 1,495 & & $1,282,300$
\end{tabular}




\section{DISTRIBUTION}

No. of

Copies

OFFSITE

12 DOE/Office of Scientific and Technical Information

M. Ginsberg

Federal Energy Management Program

U.S. Department of Energy CE-144

1000 Independence Avenue SW

Washington, DC 20585

2 L. Harris

Federal Energy Management Program

U.S. Department of Energy

CE-144

1000 Independence Avenue SW

Washington, DC 20585

12 Griffiss AFB

416 CSG/DEMC

Griffiss AFB, NY 13441

Attn: R. Petkovsek (4)

T. McDonald

S. Pike

W. Valenti

R. Lippold

R. Rapke (4)

2 T. White

HQ ACC

CETSO/ESOU

11817 Canon Blvd, Suite 500

Newport News, VA 23606-2558
No. of

Copies

ONSITE

DOE Richland Field office

D. R. Segna (A5-90)

39 Pacific Northwest Laboratory

P. R. Armstrong (K5-08)

J. W. Currie (K7-82)

K. K. Daellenbach (K6-61)

J. E. Dagle (K5-20)

F. V. Di Massa $(K 6-61)$

J. A. Dirks (K6-61)

D. R. Dixon $(K \sigma-62)(10)$

D. B. Elliott $(K 6-57)$

M. Friedrich (K5-16)

J. M. Keller (K5-08) (4)

G. B. Parker (K7-82)

D. R. Payson (K7-90)

E. E. Richman (K5-08)

S. A. Shankle (K6-57)

D. S. Stucky (K5-57)

R. R. Wahl strom (K5-08)

L. E. Wrench (K5-08)

Publishing Coordination

Technical Report Files (5) 

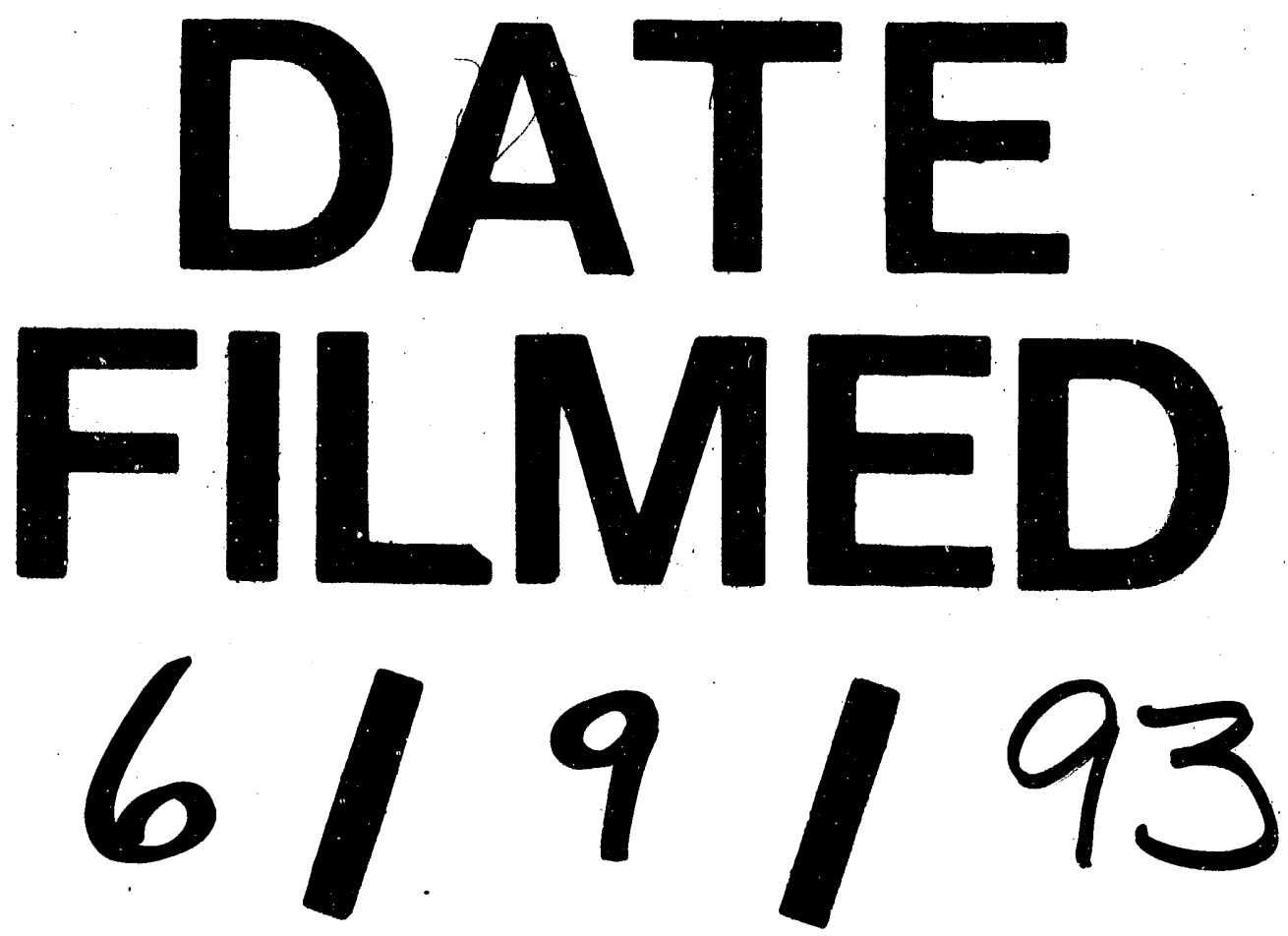
